\title{
Description and classification of Late Triassic Neritimorpha (Gastropoda, Mollusca) from the St Cassian Formation, Italian Alps
}

\author{
KLAUS BANDEL
}

Neritopsis represents the only surviving genus of an ancient group of the Neritimorpha that has no internal dissolution of its shell walls. While the two known living species have lecithotrophic early development without larval shell, Neritopsis aqabaensis $\mathrm{n}$. $\mathrm{sp}$. from the Gulf of Aqaba, Jordan, has a planktotrophic veliger. These living species of the genus differ in their protoconch shape as well as teleoconch morphology and ornament from the Triassic species that can be considered related to Neritopsis. Neritopsidae with the modern Neritopsinae is distinguished from the Triassic Cassianopsinae n. subfam. based on the genus Cassianopsis n. gen. with three species by features of their protoconch as well as the different characters of the operculum. Zardiniopsis n. gen. differs from these by higher shell shape and a smaller more complexly ornamented protoconch. Fossariopsis has a more angular shell shape. Colubrellopsinae $\mathrm{n}$. subfam. with Colubrellopsis n. gen. resembles Cassianopsis n. gen. in respect to protoconch and features of the aperture of the teleoconch, but the former has rounded whorls and an ornament of axial ribs. Among the Fedaiellidae $n$. fam. with smooth shells two species of Fedaiella are redefined. The characters of the inner lip of their aperture connect them with the Neritopsidae, whereas the operculum in the Fedaiellidae with concentric structure on the outside distinguishes them from neritopsids.

In distinction to the groups of the Neritopsoidea members of the Dephinulopsidae have a smooth inner lip of the aperture. Here Delphinulopsinae and Platychilininae n. subfam. differ from each other in the shape and ornament of their teleoconch. Schwardtopsis n. gen. resembles a juvenile Delphinulopsis grown to a larger size. The large concave callus of the inner lip and almost open coiling defines Delphinulopsis. Rows of nodes, low initial shell and rapid growth in shell diameter to an almost limpet shape characterises Platychilina, and lamellar growth increments on an almost limpet-like shell with flat initial part is present in Marmolatella. The Palaeonaricidae n. fam. contains two species of Palaeonarica, which have a Nerita-like shell with simple aperture.

The Naticopsidae of the Carboniferous and Permian has its continuation in the Ampezzonaticopsinae n. subfam. of the Triassic, being connected to each other by the sinuous ornament of ribs on their larval shells. The genera are distinguished by teleoconch shape and differences in the ornament of their larval shell. Ampezzonaticopsis $\mathrm{n}$. gen. has whorls well separated by deep sutures, Cortinaticopsis n. gen. has a simple aperture and a callus covering the umbilicus. The Hologyrinae n. subfam. with Hologyra have a ridge in the columellar furrow and an operculum that resembles that attributed to Carboniferous Naticopsis. Their protoconch has a characteristic chevron ornament on its larval whorls.

The new family Tricolnaticopsidae is proposed to hold Tricolnaticopsis n. gen. with a smooth shell and convex inner lip and color pattern of dots. Into the aperture an operculum of bean-like shape may be fitted and this operculum has quite independent characters. It would also fit with Pachyomphalus with shallow sutures and two species, one with short rounded conical shape and the other with elongate shell. Both resemble Tricolnaticopsis $\mathrm{n}$. gen. as does Rinaldopsis $\mathrm{n}$. gen. with its wide flat inner lip. Laubopsis n. gen. has an open umbilicus and has no clear connection with similar species.

The new family Scalaneritinidae is based on Scalaneritina $\mathrm{n}$. gen. with an elongate shape and axial ribs. The protoconch is rounded with its larval shell having an ornament of low, fold-like collabral ribs. Ladinaticella $\mathrm{n}$. gen. has three species: two have similar shell shape, in one case with a few strong ribs as ornament, while in another case there are many, and a third has a more rounded apex. In the case of Lancedellopsis n. gen., the shell is low, has a rapid increase in diameter and a low tooth in its aperture. Its relation to the other Neritimorpha remains undetermined.

Among the species of Neritoidea from St Cassian Formation the members of the Neritariidae are arranged into the genera Neritaria, Ruganeritaria n. gen., Dentineritaria n. gen., Oncochilus, and Cassianpisulina n. gen. The genus Neritaria has a complexly ornamented protoconch, and the related Ruganeritaria $\mathrm{n}$. gen. differs by the protoconch having only axial ribs. The operculum has the general shape of that found in modern Nerita and its relatives. Dentineritaria n. gen. has a central tooth on its inner lip and its protoconch is relatively large with straight axial ribs. The Oncochilinae is distinguished notably by projections of the inner lip into the aperture, which are two in Oncochilus and single larger one in Cassianpisulina n. gen. The latter is defined and compared with modern Pisulina. The Trachineritariinae n. subfam. with Trachyneritaria $\mathrm{n}$. gen. is distinguished by characters of the teleoconch that has the inner whorls dissolved. Its relation to Trachynerita remains problematic. $\bullet$ Key words: Gastropoda, Neritimorpha, Triassic, Tethys, Italy, Jordan, new taxa (fossil, living). 
BANDEL, K. 2007. Description and classification of Late Triassic Neritimorpha (Gastropoda, Mollusca) from the St Cassian Formation, Italian Alps. Bulletin of Geosciences 82(3), 215-274 (14 figures). Czech Geological Survey, Prague. ISSN 1214-1119. Manuscript received April 27, 2007; accepted in revised form July 30, 2007; issued September 30, 2007. • DOI 10.3140/bull.geosci.2007.03.215

Klaus Bandel, Universität Hamburg, Geologisch Paläontologisches Institut und Museum, Bundesstrasse 55, 20146 Hamburg, Germany; klausbandel@yahoo.de

The number of species of the Neritimorpha that lived in the environment of the tropical reef of the Late Triassic St Cassian Formation in the Tethys Ocean is amazingly high, compared to that found in this kind of environment today. Thirty six species can be recognized and this diversity distinguishes this Tethyan reef from modern, tropical Indo-Pacific reefs where only about 10 species may be present including the nearby shore and the lagoon. In regards to taxonomic groups within the Neritimorpha only Neritopsis among these modern genera and species can be regarded as relatively closely related to some of the species from the Cassian Reef described here. Some others can be placed with the superfamily Neritopsoidea, and some with the superfamily Neritioidea but not to any of the modern families. A few species are clearly representatives of the predominantly Paleozoic Naticopsidae, and quite a number of taxa appear to be quite unrelated to any surviving unit of the Neritimorpha. This difference is not so amazing considering the long time interval of about 220 million years that has passed between the populations of both tropical reef assemblages. The large diversity of fossil species recognized can be considered evidence for the limitations into which any DNA analysis would run when it is used in the reconstruction of a phylogenetic tree of the Neritimorpha. Most modern Neritimorpha form more closely related groups and appear to be more related to each other than to several of the groups recognized from the Late Triassic St Cassian Formation. As will be shown below, there is evidence that the diversity of the modern species of the Neritimorpha reflects only a fraction of what had been present in the past. Larger units recognized in the Triassic have not survived in any of the species living today and can, therefore, not be studied in regard to their genomic composition.

\section{The environment of the species from the St Cassian Formation}

In the St Cassian Formation of the Italian Alps, Dolomites near Cortina d'Ampezzo and St Cassian the deposits of Lower Carnian age include lagoonal sediments of well bedded, often dolomitic limestone, and rarely also along their margins deposits of deeper water consisting of marls, shale and tuffaceous deposits. This margin of the carbonate plat- form consisted of bioconstructed reefoid sediments. It is usually transformed into dolomite in those places where the actual reef is still exposed in its original position of growth. From that area material had broken off and been washed out by currents and transported down-slope. In the case it came to rest in the fine-grained sediment of the basin, which included volcanic ashes and mud derived from nearby volcanism, it was well preserved. This calcareous material was sometimes so well preserved that even aragonitic shells were not changed into calcite during diagenesis. Of the molluscan fauna that lived in the shallow water juvenile shells may preserve the early ontogenetic part of their shell, which even during life is usually destroyed by corrosion and boring. These assemblages may form layers which contain quite different gastropods, most of which have come from shallow water. Some of the shells have been covered with algal crusts before they came to rest in the mud of the deep water environment.

The gastropods of the St Cassian Formation lived during early Carnian (Cordevolian) time of the Late Triassic (Urlichs 1974, 1994). The environment was that of reefs, the lagoon behind them and their slope to the open sea which was the tropical Tethys Ocean. Here carbonate platforms forming islands in the Tethys Ocean were not very stable in their position through time and moved (Blendinger \& Blendinger 1989), probably connected to earthquakes and volcanic eruptions. The Neritimorpha here discussed have lived primarily in or near the reefs which consisted of algal mats, calcareous and stromatoporoid sponges and corals (Wendt 1982). Reefs are only exceptionally preserved in situ as in the Richthofen reef at Settsass near St Cassian (Mojsisovics 1879). In those places where parts of the reef broke off and moved down the fore-slope the reef community is well documented, for example at the localities Misurina and Alpe di Specie (Fürsich \& Wendt 1977). A map of the localities from which gastropods have been extracted from the beds of the St Cassian Formation has been provided by Zardini (1978).

Note. - All the specimens studied are housed in the Bayrische Staatssammlung für Paläontologie und Geologie München, BSPG, Germany. Other material cited is to be found in the Naturhistorisches Museum in Vienna, Austria (NHMW), and the Museum of the region Ampezzo "Ciasa de ra Regoles" at Cortina d'Ampezzo, Italy. 


\section{Systematic palaeontology}

Subclass Neritimorpha Golikov \& Starobogatov, 1975

Remarks. - In the members of this group the shell of its species differs in ornament and shape, but is generally low and consists of few whorls (Thiele 1929-1931; Wenz 1938-1944; Knight et al. 1960). The outer layer of the shell is usually calcitic and the inner layer consists of aragonitic crossed lamellar structure (Boggild 1930, Bandel 1990, Sasaki 2001). The anatomy differs from that of other groups of the Gastropoda in several details (Fretter \& Graham 1962). That of Neritopsis is closest to that of Nerita and its relatives (Holthuis 1995). The radula has many teeth in each row and resembles in that manner the Archaeogastropoda, and was therefore considered rhipidoglossate (Troschel 1856, Troschel \& Thiele 1865-1893). The protoconch is strongly involute with whorls overlapping and an egg-shaped embryonic shell (Robertson 1971, Bandel 1982).

The Neritimorpha holds the aquatic Neritoina Rafinesque, 1815 as well as the terrestrial Helicinina Thompson, 1980 and Hydrocenina Troschel, 1856. Within the Neritoina the stem group of the Neritopsidae Gray, 1847 appears with a number of species in the Devonian (Heidelberger \& Bandel 1999, Frýda 2000, Bandel \& Heidelberger 2001, Heidelberger 2001). Probably the history of the Neritimorpha can be traced to the Early Paleozoic (Bandel \& Frýda 1999).

The Neritimorpha represents the most ancient and primitive of the living groups (subclasses) of the Gastropoda with a larval shell in addition to the embryonic one. Regarding the organization of the teeth on the ribbon of the radula they resemble those of the Rhipidoglossa Mörch, 1865 (here used for Archaeogastropoda without inclusion of the Docoglossa Troschel, 1856 and Neritopsina Cox \& Knight, 1960). In shell and gill structure they are similar to the Docoglossa, which represent the most primitive order of the subclass Archaeogastropoda (Haszprunar 1988, Ponder \& Lindberg 1997, Sasaki 1998). Regarding the mode of ontogeny of their early shell as demonstrated by Bandel (1982), the Archaeogastropoda represents a subclass of the living Gastropoda with its species provided only with the embryonic and without larval shell.

Based on cleavage patterns (Biggelaer \& Haszprunar 1996) and on computer-based cladograms, Ponder \& Lindberg (1997) arrived at similar conclusions to Bourne (1908) based on anatomical analysis and Bandel (1982) based on the pattern of formation of the early ontogenetic shell. These data indicate that the Neritimorpha is an independent group within the Gastropoda and should not be seen in close relation with the Archaeogastropoda, as had been suggested by Thiele (1929-1931) and repeated ever since in most studies on the subject, and also confirmed by molecular data (Kano et al. 2002).
Superorder Cycloneritimorpha Bandel \& Frýda, 1999

Remarks. - Neritimorpha can be divided into the Paleozoic Cyrtoneritimopha with openly coiled protoconch and the Cycloneritimopha with tightly coiled protoconch.

\section{Order Neritoina Rafinesque, 1815}

Remarks. - Here can be included the aquatic Neritimorpha with the cycloneritimorph protoconch morphology. Anatomically Neritimorpha, the Neritoina is distinguished from other Gastropoda, as had been recognized by Bourne (1908) and Fretter \& Graham (1962). They observed that living species have one left kidney, a single left feather-like ctenidium (except in lung-bearing terrestrial species), a heart with one or two auricles, internal fertilization, paired retractor muscles, and a rhipidoglossate radula. The ctenidium has filaments on both sides which are attached only at its base, similar to the gill of Acmaea. It is thus considered to represent the most primitive type found among modern gastropods (Haszprunar 1988). The nerves connecting the ctenidia with each other and also the ctenidia themselves are different from those found in other gastropod groups and are therefore considered to have evolved independently from them (Thiele 1929-1931). Internal fertilization and the production of egg capsules have evolved also while in most Archaeogastropoda external fertilization is practiced. Bourne (1908) suggested that the Neritimorpha has come from primitive gastropod stock which is supported by paleontological evidence according to which pre-midDevonian Neritimorpha and their stem group representatives with uncoiled embryonic shell and openly coiled larval shell (Frýda \& Bandel 1997, Bandel 1997) range back to the early Ordovician and thus have developed independently from the rest of the Gastropoda for about 500 million years.

Bouchet \& Rocroi (2005) provided a recent classification scheme of the "clade" Neritimorpha, which differs considerably from the one suggested here, especially regarding the taxa based on fossil species.

Superfamily Neritopsoidea Gray, 1847 (= Rafinesque, 1815)

Diagnosis. - Inner walls of shell not dissolved. Calcareous operculum not spirally arranged (Wenz 1938-1944).

Remarks. - Unlike the Neritoidea the shell inner walls are not dissolved. Within the Neritimopha species belonging to the Neritopsoidea Rafinesque, 1815 do not dissolve the inner walls of their shell (Cossmann 1925, Wenz 1938-1944). This superfamily is based on members of Neritopsidae and interpreted to consist of quite a few genera in the Late Paleozoic and the Early Mesozoic (Knight et al. 
1960). The genus Neritopsis Grateloup, 1832 is reported to have existed since Jurassic time (Bandel \& Kiel 2003). Cossmann (1925) suggested that it also had Triassic representatives. Since the beginning of the Tertiary only representatives of the genus Neritopsis have survived among the Neritopsoidea.

\section{Family Neritopsidae Gray, 1847}

Diagnosis. - Globular shell with low spire and large last whorl. Inner lip of aperture broad and smooth forming a callus ribbon that has on its inner side a central depression into which fits the angular inner projection of the operculum. On the outer side of the callus a groove often forms the continuation of the umbilicus. Inner walls of shell not dissolved; operculum without spiral growth increments. Protoconch consists of low and tightly coiled rounded whorls.

Remarks. - The family is based on the genus Neritopsis.

Subfamily Neritopsinae Gray, 1847

Diagnosis. - Whorls of shell are rounded. Smooth protoconch and angular operculum of trapezoidal shape with an almost smooth thickened rounded exterior and angular grooved attachment on its inner side.

Remarks. - The taxon is based on modern Neritopsis.

\section{Genus Neritopsis Grateloup, 1832}

Diagnosis. - Medium-sized shell with rounded whorls, a moderately protruding spire, and globose last whorl with evenly convex flanks. Sculpture consists of thick, granulated spiral cords that may be intersected by axial ribs and form a reticulate pattern. Protoconch consists of smooth whorls.
Teleoconch aperture round with a moderately thickened concave inner lip and median quadrangular depression into which fits the trapeziform, solid operculum that is mineralized with calcite and has a quadrangular projection at the side held next to the inner lip when the aperture is closed.

Remarks. - The type of the genus is Neritopsis moniliformis Grateloup, 1832 from the Miocene of the Aquitaine in France, which closely resembles the still living Neritopsis radula Linné, 1757 from the Indo-Pacific as illustrated by Wilson (1993).

The protoconch is rounded with smooth whorls which in the case of an individual of Neritopsis cf. radula from the Indo-Pacific Ocean of Mauritius consist of more than two whorls (Bandel \& Frýda 1999, pl. 1, figs 1, 2), as is also the case in Neritopsis aqabaensis described below from the Gulf of Aqaba. Neritopsis parisiensis Deshayes, 1864 from the Eocene of the Paris Basin has only a little more than one whorl (Bandel \& Frýda 1999, pl. 1, figs 3, 4), as is usual case in living Neritopsis radula from the Indo-Pacific (Kano \& Kase 2000, Kaim \& Sztajner 2005, fig. 4C). The protoconch of Neritopsis atlantica Sarasua, 1973 from the Caribbean Sea is not known.

The operculum of Neritopsis is of characteristic trapezoidal shape and has calcitic composition. Jagt \& Janssen (1988, pl. 2, figs 1-3) noted opercula of Neritopsis in the Paleocene of the Province Limburg in Belgium. The operculum of living Neritopsis has a convex outer surface and a concave inner side with an inner projection that is angular and fits into a groove present on the inner lip of the aperture (Zittel 1895, Scott \& Kenny 1998); even though it resembles in shape that of Cassianopsis n. gen., it differs in detail. The Triassic species of Cassianopsis n. gen. of the St Cassian Formation of Cortina d'Ampezzo (Zardini 1978, pl. 15, figs 11-15) have an operculum of similar shape to that of a not more closely specified Neritopsis from the Jurassic (Kaim \& Sztajner 2005, fig. 1). In the case of Neritopsis on the inner side the margin is smooth

Figure 1. A - juvenile shell of Neritopsis aqabaensis n. sp. representing the holotype with a rounded protoconch and slit-like umbilical groove in the teleoconch. The shell is $1 \mathrm{~mm}$ high (BSPG 2007 XVI 1). • B - a more apical view of Neritopsis aqabaensis $\mathrm{n}$. sp. as in Fig. 1A. • C - protoconch of Neritopsis aqabaensis n. sp. having the embryonic shell succeeded by the smooth whorl of the larval shell. $\bullet$ D - the aperture of Cassianopsis armata (Münster, 1841) has an angular depression on the inner side of its inner lip. The shell is $1.8 \mathrm{~mm}$ high (BSPG 2007 XVI 2). $\bullet$ E - apical view of Cassianopsis armata (Münster, 1841) with the rounded protoconch succeeded by an ornamented teleoconch with a pattern of axial and spiral ribs. The shell is $1.8 \mathrm{~mm}$ wide. $\bullet \mathrm{F}$ - the protoconch of Cassianopsis armata (Münster, 1841) has a fine sinuous axial ornament on its larval whorls and is about $0.5 \mathrm{~mm}$ wide. Detailed view of Fig. 1E. $\bullet \mathrm{G}$ - Cassianopsis armata (Münster, 1841) with the operculum preserved in the aperture with is outer part ornamented by concentric lines and its inner part smooth. The shell is about 5 mm wide (BSPG 2007 XVI 3). • H - the inner lip of Cassianopsis ornata (Münster, 1841) with its characteristic angular depression. The shell is $3.2 \mathrm{~mm}$ high (BSPG 2007 XVI 6). • I - the protoconch of Cassianopsis armata (Münster, 1841) has an ornament that reflects its lobed margin. The protoconch is about $0.5 \mathrm{~mm}$ wide. Detailed view of Fig. $1 \mathrm{~K}$. $\bullet \mathrm{J}-$ apical view of the shell of Cassianopsis armata (Münster, 1841) with the protoconch shown in Fig.1L. The shell is about 1 mm wide (BSPG 2007 XVI 4). - K - Cassianopsis armata (Münster, 1841) with an ornament of axial ribs that form spines at their intersection with the larger spiral ribs. The shell is about $2 \mathrm{~mm}$ wide (BSPG 2007 XVI 5). $\bullet \mathrm{L}$ - this protoconch of Cassianopsis armata (Münster, 1841) is about $0.5 \mathrm{~mm}$ wide with the marginal lobe of the larval shell reflected in the sinuous ornament. Detailed view of Fig. 1J. $\bullet \mathrm{M}-$ this shell with about three whorls of the teleoconch of Cassianopsis ornata (Münster, 1841) is about $11 \mathrm{~mm}$ wide with an ornament of axial and spiral ribs and a wide umbilical furrow (BSPG 2007 XVI 7). $\bullet$ N - the protoconch of Cassianopsis ornata (Münster, 1841) has more than three whorls and distinct sutures. $0.8 \mathrm{~mm}$ in width. 


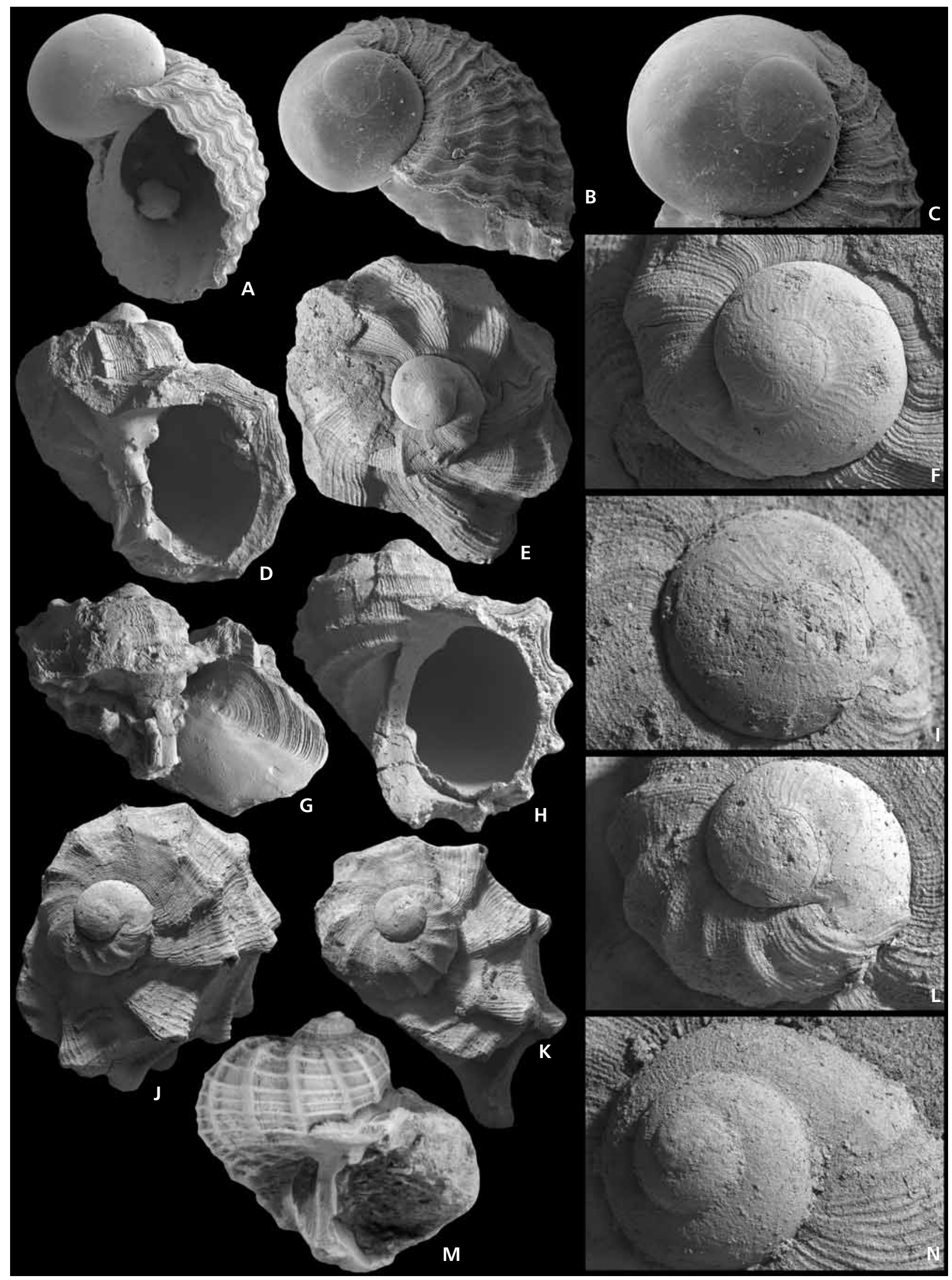


with an angular inner projection that is accompanied by two pits. A pattern of elongate grooves covers the inner extension. This resembles the operculum of Naticopsis from the Carboniferous and of Hologyra from the Triassic but the latter does not have the inner rectangular projection on the inner side as is found in Neritopsis and Cassianopsis (see below).

The shell structure of Neritopsis radula was analyzed with the scanning electronic microscope and x-ray diffraction, and accordingly the outer layer is calcitic. Its thickness differs in relation to the ornament. In ribs it is thicker than between ribs. The aragonitic layer added below the outer calcitic layer was deposited on the smooth and evenly rounded surface of the inner whorl. Deposition at the margin of the shell aperture during shell growth is by calcitic sheets on top of each other. These platy layers have the single calcitic biocrystallites growing in different directions but about parallel to shell surface. When fractured the calcitic layer appears to have an irregular structure since the direction of crystallites in these sheets differs from each other. Below the calcitic outer layer a fractured shell demonstrates crossed lamellar structure with the largest sheets arranged parallel to the margin of the outer lip in very regular orientation. Smaller sheet-like lamellae composing these and the third order needle-like lamellae are characteristic of shells of the Neritimorpha (Bandel 1990). The shell of Neritopsis is thus not composed of two wholly aragonitic layers as was suggested by Kaim \& Sztajner (2005) who relied on a report by Suzuki et al. (1991), but consists of a calcitic outer layer and aragonitic inner layer.

\section{Neritopsis aqabaensis n. sp.} Figure $1 \mathrm{~A}-\mathrm{C}$

Holotype. - The specimen illustrated here is deposited in the collection of the Bayrische Staatssammlung für Paläontologie und Geologie München, BSPG 2007 XVI 1.

Diagnosis. - Teleoconch shape as in Neritopsis radula. Protoconch consists of two rounded whorls. Embryonic whorls surrounded and largely covered by larval shell.

Derivation of the name and type locality. - This species was found in the fringing reef at Aqaba, in front of the Marine Science Station and it is named according to its type locality, the Gulf of Aqaba near Aqaba, Jordan. Individuals live within the fringing reef in crevices and cavities within shallow water of less than $3 \mathrm{~m}$ in depth. Here water in summer may be more then $30{ }^{\circ} \mathrm{C}$, in winter it sinks below $20^{\circ} \mathrm{C}$.

Description. - The protoconch is well rounded and smooth and measures about $0.4 \mathrm{~mm}$ in diameter. The embryonic whorl is egg-shaped with growth lines and the later larval shell consists of one smooth rounded whorl that overlaps strongly onto the embryonic whorl. The margin of the larval shell expands into a sinuous rim. Change to the ornamented teleoconch is abrupt. The fully-grown teleoconch is of medium size with upright spire and has a globose last whorl with evenly convex flanks. Sculpture consists of thick granulated spiral cords which are intersected by narrow axial ribs. At these intersections are formed rounded tubercles. The orbicular aperture has a moderately thickened concave inner lip that has a quadrangular depression in the middle into which the inner projection of the operculum is fitted. Next to the callus of the inner lip of the juvenile shell lies a narrow cleft-like umbilical furrow. The adult shell as well as the operculum are the same as is found in Neritopsis radula.

Differences. - The protoconch of Neritopsis aqabaensis $\mathrm{n}$. sp. has two whorls in contrast to the one present in the case of Neritopsis radula as shown by Kano \& Kase (2000) and Kaim \& Sztajner (2005). A similar protoconch as that in Neritopsis aqabaensis had been described by Bandel \& Frýda (1999, pl. 1, figs 1, 2). Neritopsis radula (Linné, 1758) as illustrated and described by Wilson (1993) from Australia is the characteristic Indo-West Pacific form and it has the same shape of teleoconch as does Neritopsis aqabaensis from the Red Sea. Adult shells found at Aqaba are rare and it was not possible to check if they belong to the new species or instead represent Neritopsis radula since their protoconch is not preserved, as is usually the case in larger shells. The embryonic shell of Neritopsis aqabaensis has growth lines, as is characteristic of those of the Neritidae as well as in contrast to those of most other Gastropoda that hatch as planktotrophic veligers from their egg mass (Bandel 1982).

Subfamily Cassianopsinae n. subfam.

Type genus. - Cassianopsis n. gen.

Diagnosis. - Shell whorls ornamented by axial and spiral ribs, with aperture rounded. A basal and an apical tooth are present on inner side of inner lip and between these a concave zone, into which the inner side of operculum may be fitted. Protoconch low, rounded and ornamented by low somewhat undulating axial ribs and spiral lines consisting of three whorls. Operculum trapezoidal, its outer surface with a smooth inner side and a concentric outer side. Two attachment scars present on its interior surface.

Composition. - The subfamily is based on Cassianopsis n. gen. and also includes Zardiniopsis n. gen., both from the Late Triassic St Cassian Formation. 
Differences. - The ornamented protoconch clearly distinguishes Cassianopsinae n. subfam. from the Neritopsinae, which has a smooth larval shell. The shape of the operculum connects it to the Neritopsinae, but also shows differences in detail. The teleoconch shape in the Cassianopsinae is more angular, has deeper sutures, and smaller shells than are present in the Neritopsinae. As in the case of Zardiniopsis n. gen. the protoconch in the subfamily consists of about three whorls.

Remarks. - In addition to Cassianopsis and Zardiniopsis from the St Cassian Formation, the genera Weitschatopsis Frýda, Blodgett \& Stanley, 2003 and Wallowiella Frýda, Blodgett \& Stanley, 2003 from the Late (Upper) Triassic Wallowa Terrane of Oregon, USA, can also be included in the Cassianopsinae. The ornament of the teleoconch is similar. The shell of Weitschatopsis is flat on the top, which differentiates it. The spire of Cassianopsis in contrast is pointed, and that of Zardiniopsis is high. The shell in the case of Wallowiella, described as Neritopsis (Wallowiella), is more rounded, resembling that of the more modern Neritopsis, but has a narrow and quite distinct umbilical furrow, as in Cassianopsis (Frýda et al. 2003, figs 1-13). The protoconch of Weitschatopsis and Wallowiella is not preserved, but the character of the inner lip is like that in Cassianopsis, which is evidence also for an operculum of the type as in the Neritopsidae.

\section{Genus Cassianopsis n. gen.}

Type species. - The genus is based on Naticella armata Münster, 1841, from the St Cassian Formation.

Diagnosis. - Shell with stair-like spire, about as wide as high consisting of rounded whorls with an ornament of axial and spiral ribs that form a coarse reticulate network. Axial ornament appears developmentally on the first part of the teleoconch, the spiral ornament a little later. Inner lip of teleoconch is almost straight forming a narrow callus band that on its inner side bears an apical and a basal tooth with a weak depression between. Next to the callus, a triangular groove separates the apertural margin from the ornamented whorls. A slit or narrow umbilicus present connected to the umbilical groove, which has increments of growth. Outer surface of operculum with smooth outer basal section and central nucleus with the outer half bearing concentric growth increments forming a semicircle. On the inner side are two muscle scars and a rounded smooth projection that fits into the inner side of the outer lip (Zardini 1978, pl. 15, figs 12, 13). Protoconch with three low rounded whorls which overlap and have a diameter of about 0.5 to $0.8 \mathrm{~mm}$. Aperture of larval shell with rounded lobe in outer lip. Ornament of larval whorls consists of collabral low rounded ribs.
Differences. - The protoconch of Cassianopsis consists of about three whorls and the larval shell has axial ornament, while the larval shell of Neritopsis is smooth. The species of Palaeonarica differ in regard to the shape of the inner lip of the aperture which is smooth on its inner surface. The teleoconch has a spiral ornament as in Palaeonarica. Weitschatopsis has a rectangular pattern of shell ornament as may be present in Cassianopsis, but in contrast the apical surface of the spire is concave (Frýda et al. 2003, figs 1-7, Nützel \& Erwin 2004, fig. 7A-G). The larval shell is unknown, as in Fossariopsis (with angular shoulder) and also in Weitschatopsis.

Name. - The species of this genus are characteristic for the St Cassian Formation and they have the characters of a $\mathrm{Ne}$ ritopsis and so the name for the new genus is of free combination of Cassian and Neritopsis.

Remarks. - Zittel (1895) recognized that the operculum of St Cassian species (Rhynchidia of Laube 1869) belong to Neritopsis-like gastropods. Koken (1889) found in the case of Cassianopsis armata (Münster, 1841) that the callus of the inner lip bears impressions of the inner projection of the operculum. He, therefore, concluded their resemblance and relationship with modern Neritopsis. The operculum of Cassianopsis was illustrated from the Triassic of the Hungarian Bakony by Kittl (1901, pl. 2, fig. 9) and here the features described below are well documented. The operculum of Cassianopsis resembles that of Neritopsis subvaricosa Brösamlen, 1909 from the Jurassic (Kaim \& Sztajner 2005, fig. 1A-C), but to a lesser degree that of modern Neritopsis, where the smooth part on the outside is much larger and the semicircular outer part has no concentric lines. Frýda et al. (2003) described from North America (State of Oregon) a new genus and species Bandelopsis orgegonensis which was considered to be close to Cassianopsis armata and even conspecific with Neritopsis decussata (Münster, 1841) from the St Cassian Formation. However, even though the shell shape and ornament are very similar, the shape of the inner lip of Bandelopsis oregonensis is simple and without callus, and, most important, without a central depression on its inner side. Therefore, it does not belong in the Neritopsidae. Zardini (1978, pl. 15, figs 12, 13) illustrated the muscle scars and a rounded smooth projection.

\section{Cassianopsis armata (Münster, 1841)} Figure 1D-G, I-L

Diagnosis. - Shell is as high as wide with three whorls on teleoconch. Intersection points of axial and spiral ribs on whorls of teleoconch bears spikes. Protoconch of three rounded whorls and $0.5 \mathrm{~mm}$ in size with ornament consisting of low collabral ribs on larval whorls. 
Description. - The shell is about as wide as high and has a relatively high spire. Ornament of the teleoconch consists of 6-10 strong axial ribs which represent former apertural thickenings and 6-9 spiral ribs which have a variable number of finer spiral lines between them. A shell with about 2.5 whorls of the teleoconch is about $6 \mathrm{~mm}$ high and wide. The ornament of the whorls varies from early to later whorls, with fine spiral ribs successively appearing between the larger spiral ribs. The overall ornament is reticulate with a network of squares with spiny corners developed where larger axial and spiral ribs cross. Sutures are deep and whorls clearly distinct from each other. The apical side of whorls is a little flattened and the periphery is occupied by a strong spiral rib. The aperture is semicircular. The narrow callus ribbon of the inner lip covers the umbilicus and is accompanied by a wide deep furrow next to it that begins in the umbilicus. The inner side of the inner lip has the characteristic rectangular median depression with teeth on both its sides. The outer lip is rounded and ends in a sharp edge. Shell width increases rapidly just behind the interior side of the apertural edge. An inner rim is thus produced on which the margin of the operculum had rested.

The protoconch has a rounded shape with the three whorls overlapping and the suture consisting of only a line that is not impressed. Ornament of the larval whorls consists of collabral low axial ribs which reflect a low lobe on the outer lip of the aperture. The size of the protoconch is less than $0.5 \mathrm{~mm}$. There is a noticeable and strong change in the ornament from the protoconch to the teleoconch as the collabral ribs in the latter are more lamellar and closer to each other without a lobe. In addition, the outer layer of the teleoconch has a calcitic construction and its surface appears rougher.

Differences. - Cassianopsis armata resembles Cassianopsis ornata and Cassianopsis decussata in the shape of the shell and the organization of the apertural margin. Also, their peotoconchs are similar to each other in shape, although it is larger in Cassianopsis ornata. Differences lie largely in the ornament of the teleoconch which is reticulate with axial ribs not much stronger than the spiral ribs in Cassianopsis armata, while they are stronger and more rounded in Cassianopsis ornata. In the case of Cassianopsis decussata, the spiral ribs are more irregular and have tubercles.

The whorls of Neritopsis are more rounded, sutures are less deep, and the fully-grown shell is larger. The operculum resembles that of Neritopsis, but differs in regards to the outer side. Here the part that fits with the outer lip of the aperture is occupied by a semicircle with well-developed growth lines and nucleus at its central base. Such a semicircle is not found in the operculum of Neritopsis, which has a narrow rim without growth lines. In addition, the inner side also differs with two rounded attachment scars present in Cassianopsis, whereas these are represented by narrow pits at the base of the angular depression in Neritopsis. Also, the inner projection of Cassianopsis is rounded and smooth, while it is angular and covered by longitudinal furrows in Neritopsis. The groove on the inner lip is deeper in Neritopsis than it is in Cassianopsis.

Remarks. - The original name Naticella armata was provided for this species by Münster (1841). Neritopsis waageni Laube, 1868 represents a variety of Cassianopsis armata, and is the same as Naticella cancellata Münster, 1841. Naticella plicata Giebel, 1852 is also the same species as was noted by Kittl (1892). In addition, Leonardi \& Fiscon (1959) noted several varieties of their Neritopsis armata. The different species and subspecies reflect the large variability in the ornament of individuals of Cassianopsis armata.

\section{Cassianopsis ornata (Münster, 1841)}

Figure $1 \mathrm{H}, \mathrm{M}, \mathrm{N}$

Diagnosis. - Round shell with three whorls in teleoconch. Dominant ornament of rounded strong axial ribs crossed by many smaller spiral ribs. Umbilicus closed or slit-like. First teleoconch whorl ornamented with fine lamellar axial ribs; stronger ribs appear later. Protoconch measures about $0.8 \mathrm{~mm}$ with more than three whorls with larval whorls ornamented with weak collabral ribs.

Description. - The shell shape closely resembles that of Cassianopsis armata, round with deep sutures and a low spire, which has a rapid increase in whorl diameter. However, unlike Cassianopsis armata, there are 7 to 11 varixlike axial ribs crossed by 18-20 spiral ribs of different size. The umbilicus is narrow, slit-like or closed. The aperture is circular and the outer lip is simple and thin at its margin, but thickened further inward, forming a rim on which the operculum rested. The inner lip forms a narrow callus ribbon with a central depression on its inner side accompanied by ridges on each end. A shell with more than three whorls on the teleoconch is almost fully-grown and about $9 \mathrm{~mm}$ high and $11 \mathrm{~mm}$ wide.

The protoconch consists of more than three whorls with larval whorls ornamented by low axial ribs. A large part of the embryonic shell is covered by the larval whorls which overlap onto it. Their ornament consists of about 30 collabral ribs on one whorl. Ribs follow the outline of the margin of the outer lip that has a rounded lobe. With the exception of the embryonic and first larval whorl a distinct suture is developed. Ornament of the first whorl of the teleoconch is quite similar to that in Cassianopsis armata, consisting of fine lamellar collabral straight ribs, which appear with the change from the aragonitic shell of the 
protoconch to the calcitic construction of the outer shell layer of the teleoconch.

Differences. - Cassianopsis armata has stronger axial ribs than Cassianopsis ornata, and spikes where the ribs cross each other. Cassianopsis decussata has a denser ornament of fine spiral lines, has tubercles, and reaches larger size when fully-grown. Zardiniopsis subornata has a relatively higher shell and a smaller protoconch with ornament also consisting of spiral ribs.

Remarks. - Kittl (1892, pl. 5, figs 10-12) and Zardini (1978, pl. 14, fig. 18) documented the species as Neritopsis ornata. Part of the individuals determined as Neritopsis armata and Neritopsis decussata by Zardini (1978, pl. 15, figs 4-6) are also close to Cassianopsis ornata.

\section{Cassianopsis decussata (Münster, 1841)} Figure 2E, G-J

Diagnosis. - Broadly globular shell with strong spiral ribs and fine spiral ribs crossed by axial ribs forming tubercles with each other. Ornament of larval whorls in rounded protoconch consists of short, narrow axial ribs well developed next to the suture.

Description. - The protoconch measures about $0.5 \mathrm{~mm}$ and has a rounded shape. The aperture of the larval shell is provided with a rounded low median lobe. The embryonic shell is succeeded by about two larval whorls, which are ornamented by fine collabral ribs.

The juvenile teleoconch has sinuous growth lines for a half whorl before the spiral ornament appears. The periphery is angular and here as well as on the sides and base spiral ribs are present with 12 to 13 tubercles found on them in each whorl. The aperture is somewhat oblique, of oval shape, and higher than wide. The callous inner lip has a concave columellar edge with a rounded tooth below and above. Its callus may cover the slit-like narrow umbilicus. A shell with $8 \mathrm{~mm}$ in height is about $7 \mathrm{~mm}$ wide and consists of three whorls of the teleoconch. The body whorl has about 15 axial ribs which form rounded tubercles where they are crossed by spiral ribs. These later are quite variable in size and thus different individuals appear to have a different ornament.

Differences. - Cassianopsis decussata differs from Cassianopsis ornata and Cassianopsis armata in having an ornament of finer and more numerous spiral lines. Its protoconch is similar to that of Cassianopsis armata in size and shape. Ornament of the larval whorls is finer and axial ribs are arranged more densely. The shell of Zardiniopsis subornata is higher and has a smaller protoconch with an ornament also composed of spiral ribs. The first whorl of the teleoconch has an ornament of only collabral lines, and axial ornament, which differs from the species of Cassianopsis with earlier origin of spiral ribs, appears later.

Remarks. - The species was originally called Naticella decussata by Münster (1841) but also Naticella nodulosa Münster, 1841 (Münster 1841, pl. 10, figs 20-22), and Naticella cincta Klipstein, 1843, while Laube (1869, pl. 17, fig. 31) called it Neritopsis decussata, as did Kittl (1892, pl. 5, figs 17-23). The latter author, however, also created Palaeonarica cancellata Kittl, 1892 that probably represents the same species. It was called Palaeonarica hologyriformis Blaschke, 1905 from the Seiser Alp (Blaschke 1905, pl. 19, fig. 20) repeated by Broili (1907, pl. 7, figs 40, 41). Zardini (1978, pl. 15, fig. 8) determined it as Neritopsis subornata; Zardini (1980, pl. 3, figs 11-13) as Palaeonarica pyrulaeformis cf. nodosa; and then as Paleonarica mortisanensis Zardini, 1985 (Zardini 1985, pl. 5, fig. 13). Transitions connect with Neritopsis rumerloensis that has been proposed by Leonardi \& Fiscon (1959) and may simply represent varieties.

\section{Genus Zardiniopsis n. gen.}

Type species. - The genus is based on Naticella subornata Münster, 1841 from the St Cassian Formation.

Diagnosis. - Slender and conical shell with smaller protoconch. Larval shell with ornament of sinuous axial ribs crossed by fine spiral ribs provided with a sinuous outer lip. Early teleoconch ornamented only by fine collabral ribs. Spiral ornament initiates at the end of first whorl and axial ornament even later. Flat ribbon of callus of inner lip has a rectangular indentation on its inner side and is accompanied by a long narrow columellar furrow. Shell consists of very fine calcitic outer layer and thick aragonitic inner layer composed of crossed lamellar structure.

Name. - This new genus, with apertural features resembling those of Neritopsis is named in honor of Rinaldo Zardini, who collected and described many of the St Cassian gastropods. Zardiniopsis n. gen. represents a free combination of both names with Zardini connected to the end of Neritopsis.

Differences. - The shells of Zardiniopsis n. gen. are higher than wide with a conical initial part of the teleoconch, differing from Cassianopsis n. gen. in which the shell is as wide as high and in which the first whorls of the teleoconch are low. Features of the aperture are like those of Cassianopsis n. gen. Ornament resembles that of Cassianopsis ornata, but ribs appear later. In addition, the smaller and 
more ornamented protoconch of Zardiniopsis n. gen. distinguishes it from other similar genera. Details of the operculum in Zardiniopsis n. gen. are still not known. Perhaps the operculum described by Zardini (1978, pl. 15, fig. 15a, b) belongs here, with its wide, evenly rounded outer side and an inner side with two deep lateral depressions next to the median lobe.

\section{Zardiniopsis subornata (Münster, 1841)} Figure 2A-D, F

Diagnosis. - Shell higher than wide with spiral ribs narrower than the rounded axial ribs. Globular protoconch measuring $0.35 \mathrm{~mm}$ is ornamented by collabral ribs that reflect the appearance of a sinus in the outer lip of the larval shell and by spiral ribs. Ornament of larval shell appears to be reticulated. Rounded conical early teleoconch with an ornament of fine, straight collabral lines. Spiral ornament beginning on second whorl of teleoconch; broad axial ribs appear later.

Description. - The shell is relatively high and of fusiform shape. The aperture is oval, higher than wide and the callus of the inner lip is a narrow ribbon with the deep slit-like umbilicus open or covered. The callus is widest in the apical region and of even width below. Here it is accompanied on its outer side by the umbilical furrow. This groove has a keel on its outer margin in which the axial ribs of the ornament on the whorls end. The ornament consists of rounded large varix-like axial ribs crossed by irregular and lower spiral ribs. While the spiral ribs initiate at the end of the first whorl of the teleoconch, the axial ribs appear on the third whorl. The shell is relatively high and of fusiform shape. A fully-grown shell consists of about 3 whorls in the teleoconch and is about $8-10 \mathrm{~mm}$ high and $5 \mathrm{~mm}$ wide. The umbilicus may be wide, but it may also be closed by the callus ribbon of the inner lip. The teeth on the inner side of the inner lip are small and distant from one another, one tooth is next to the apical end and the other tooth is next to the basal end of the inner lip. The angular groove between the teeth is shallow but distinctly developed.
The protoconch is evenly rounded globular and measures about $0.35 \mathrm{~mm}$ in diameter and consist of a little more than 2.5 whorls. Its ornament consists of many collabral rounded ribs which are crossed by fine spiral lines to form a reticulate pattern. A sinus is developed that is well recognized in the transition to the teleoconch. The outer lip of the fully-grown larval shell is upturned and has a thickened margin.

As noted above, it may be that the operculum illustrated by Zardini (1978, pl. 15, fig. 15; 1985, pl. 3, fig. 19) belongs to Zardiniopsis n. gen. In that case it resembles that of Cassianopsis n. gen., but is wider and has an ornamented inner side of its inner projection, and is also that of modern Neritopsis. Like the latter it has a trapezoidal shape with the inner side towards the inner lip with grooves, similar to that illustrated by Knight et al. (1960, fig. $182,9 \mathrm{~b})$, but with the sides and the outer margin less rounded.

Differences. - The shell is relatively higher than that of Cassianopsis n. gen., but resembles it in the style of the ornament that consists of fine lamellar growth lines on its base; these are part of the calcitic outer shell layer. The ornament of the protoconch and its smaller size distinguishes it from that in Cassianopsis n. gen. The reticulate pattern of the ribs on the larval shell distinguishes it from the sinuous ornament of that in Hologyra. There is no corner on the shoulder of the body whorl, as is the case in Fossariopsis, which also has a relatively high shell. Nützel \& Erwin (2004, fig. 7L-Q) suggested that Nuetzelopsis Frýda, Blodgett \& Stanley, 2003 from the Late Triassic from western USA might be related to Cassianopsis n. gen. and Nuetzelopsis tozeri may even represent the same genus as Cassianopsis subornata. This is clearly not so as their illustration documents, since the inner lip of their species is rounded and smooth. Where to put Nuetzelopsis in the taxonomic system is still quite unknown, and this genus may even belong to some other gastropod group, rather than the $\mathrm{Ne}$ ritimorpha. Neither shell structure nor protoconch morphology of Nuetzelopsis is known (Frýda et al. 2003, figs 25-38).

Figure 2. A - the inner lip of Zardiniopsis subornata (Münster, 1841) with an angular depression on its inner side. The shell is about 1.8 mm high (BSPG 2007 XVI 8). • B - this juvenile shell of Zardiniopsis subornata (Münster, 1841) with ornament and a callus plate is about 4 mm high (BSPG 2007 $\mathrm{XVI} 9$ ). $\bullet \mathrm{C}$ - the juvenile shell of Zardiniopsis subornata (Münster, 1841) with the beginnings of the spiral ornament. The shell is about $1 \mathrm{~mm}$ high including the rounded protoconch (BSPG 2007 XVI 10). • D - the protoconch of Zardiniopsis subornata (Münster, 1841) has an ornament of axial and spiral ribs and measures about $0.35 \mathrm{~mm}$ in diameter. $\bullet \mathrm{E}$ - protoconch of Cassianopsis decussata seen from above, same as in Fig. $2 \mathrm{H}$. $\bullet \mathrm{F}-$ larval shell and juvenile teleoconch of Zardiniopsis subornata (Münster, 1841) showing change in ornament at the lobed margin of the protoconch. The shell is about $1 \mathrm{~mm}$ high (BSPG 2007 XVI 11). $\bullet \mathrm{G}$ - this protoconch of Cassianopsis decussata (Münster, 1841) has collabral ornament and measures about $0.5 \mathrm{~mm}$. - $\mathrm{H}$ - protoconch of Cassianopsis decussata (Münster, 1841) seen from the side with its ornament restricted to the apical part of the larval shell. The protoconch is about $0.5 \mathrm{~mm}$ wide. $\bullet \mathrm{I}$ - a juvenile shell with protoconch of Cassianopsis decussata (Münster, 1841) with a diameter about $1.2 \mathrm{~mm}$ wide (BSPG 2007 12). $\bullet \mathrm{J}$ - protoconch of Cassianopsis decussata (Münster, 1841) measuring about $0.5 \mathrm{~mm}$ and as a fine ornament of short axial ribs on the apical side of larval whorls. Detailed view in Fig. 2I. $\bullet$ K - a juvenile shell of Fossariopsis rugosocarinata Laube, 1868 with the inner lip and in which its upper inner ridge can be seen (BSPG 2007 XVI 13). $\bullet$ - the same shell (Fossariopsis rugosocarinata Laube, 1868) seen from the back. The shell is $15 \mathrm{~mm}$ high. 


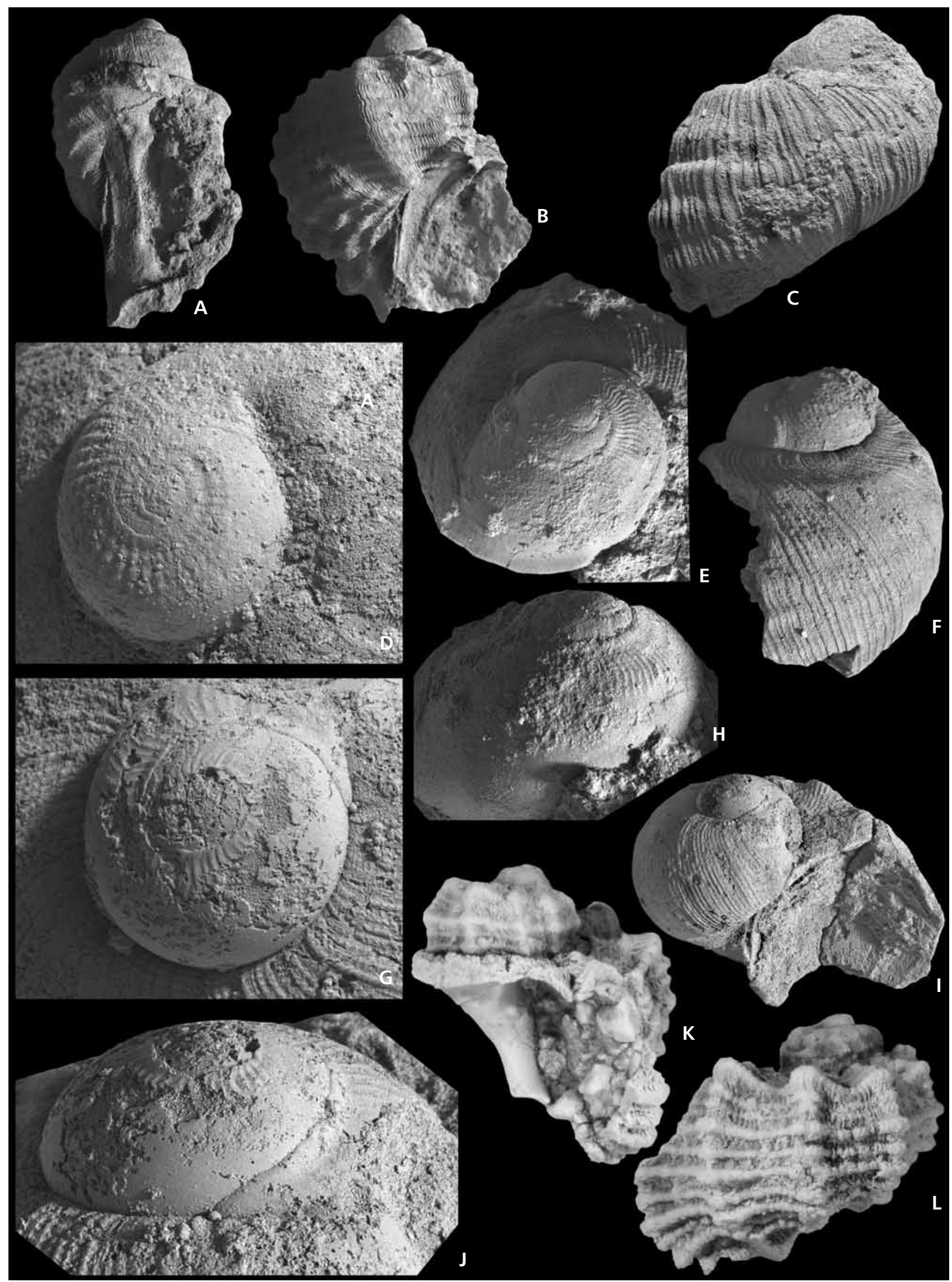


Remarks. - The species had originally been named Naticella subornata by Münster (1841) and was determined as Neritopsis subornata by Laube (1869). The species studied and illustrated by Kittl (1892, pl. 6, fig. 13) was based on specimens from NHMW, which agree with the individuals collected from Seelandalpe (Alpe di Specie) and studied here. The characteristic shell was documented by Zardini (1978, pl. 15, figs 7-10).

\section{Genus Fossariopsis Laube, 1869}

Type species. - The genus is based on Fossariopsis rugosocarinata (Klipstein, 1843) from the St Cassian Formation.

Diagnosis. - Shell angular with a flattened apical side on its whorls and rounded transition to the base. Ornament consists of axial rows of tubercles and narrow spiral ribs. Of the rows of tubercles, one situated at the upper corner may form short, hollow, gutter-like spines. Inner side of inner lip of aperture has two teeth and a median depression. Protoconch unknown. Inner whorls of shell are not dissolved.

Differences. - Fossariopsis differs from Zardiniopsis n. gen. by its larger size and a distinct apical corner on its whorls. Its shell is more elongate and has angular whorls in comparison to Cassianopsis n. gen. Palaeonarica differs by its ornament of dominating keels, a relatively wider shell and smooth inner side of the inner lip. Whorls expand more rapidly in Platychilina. Fossariopsis is distinguished from Delphinulopsis by having its whorls not detached from each other in the later part of the teleoconch and by not forming a depressed and extended callus of the inner lip. The latter two genera, in addition, also differ in having a smooth inner side of the inner lip.

Remarks. - Fossariopsis as described here is based on the individuals determined as Palaeonarica rugosocarinata by Zardini $(1978$, pl. 17, figs 11, 12), not on those of Zardini (1978, pl. 17, figs 13-15), which represent juvenile individuals of Palaeonarica concentrica. Laube (1869) recognized in Pleurotomaria binodosa Münster, 1841 two different species one of which he assigned to Fossariopsis and the other to Delphinulopsis. Kittl (1892, pl. 6, fig. 18) suggested that Fossariopsis rugosocarinata represents a Palaeonarica. The type of Fossariopsis rugoso-carinata was based on a poorly preserved specimen, and Zittel (1895) united both genera in the genus Delphinulopsis. Koken (1889), in contrast, suggested replacing Delphinulopsis with Fossariopsis, as was adopted by Wenz (1938-1944), who stated that Fossariopsis and Delphinulopsis are based on the same type species and therefore are synonyms. In fact Fossariopsis muensteri Laube, 1869 is the same species as Delphinulopsis binodosa (Münster, 1841). Yin \& Yochelson (1983) noted the stair-like shell shape of Fossariopsis and a rapid increase in shell diameter. They suggested that the ornament of two spiral keels, one at the apical edge and a weaker keel on the corner to the base could be regarded as characters with which to reevaluate the genera of Laube (1869). Even though their diagnostic character does not deviate from that of Wenz (1938-1944), it is based on a different type species. Yin \& Yochelson (1983) regarded Delphinulopsis binodosa, and Fossariopsis rugosocarinata as representing different genera and retained Fossariopsis as an independent genus with the type species Fossariopsis rugosocarinata.

\section{Fossariopsis rugosocarinata (Klipstein, 1843)} Figure 2K, L

Diagnosis. - Shell with an angular apical margin and a row of nodes or hollow spines. Ornament consists of numerous narrow spiral tubercle-bearing ribs where crossed by the wide and rounded axial ribs. Inner lip is accompanied by outer columellar furrow and two teeth and a median depression on its inner side.

Remarks. - The species has the characters of the genus.

Description. - A shell with four whorls of the teleoconch is about $16 \mathrm{~mm}$ high and $15 \mathrm{~mm}$ wide. It has a low spire and whorls are arranged in a stair-like manner increasing rapidly in diameter. The apical corner of whorls is enforced by axial ribs that carry tubercles where they cross the corner. These can also be developed as hollow spines (Zardini 1978 , pl. 17, figs 11, 12). A shell with 2.5 whorls of the teleoconch is about $8 \mathrm{~mm}$ high and wide. Its peripheral edge carries about 13 coarse tubercles or gutter-like spines. The edge to the base has weaker tubercles. On the rounded base three tubercle-bearing spiral ribs are present which have fine spiral lines between them. Growth lines are straight and may be strong and lamellar. The aperture is semicircular with a straight inner lip that forms a narrow continuous callus ribbon. The umbilical depression may be covered by the callus, or it leaves a narrow deep open slit. On the inner side of the inner lip two teeth indicate the area into which the projection of the operculum was fitted. An umbilical groove with growth increments ends in the base at the outer lip. The margin of the outer lip is acute. A little further into the shell interior the wall increases in thickness thus forming an internal rim which provided a good support on which the operculum rested. The protoconch is still unknown, as well as the operculum. Predictably, it would probably resemble that of Cassianopsis n. gen. in general shape and outline. The inner walls of the shell are not dissolved. 
Differences. - Fossariopsis rimbianchi (Zardini, 1985) and Fossariopsis sinense (Yin \& Yochelson, 1983) both have a fine pattern of spiral ornament on their surface, as can also be present in individuals of Fossariopsis rugosocarinata; all three species may represent the same or very similar species. Palaeonarica concentrica and Palaeonarica pyrulaeformis differ not only by having a lower shell shape, but also in having a smooth simple inner lip without central depression and inner teeth.

Subfamily Colubrellopsinae n. subfam.

Type genus. - The subfamily is based on the genus Colubrellopsis $\mathrm{n}$. gen. from St Cassian Formation.

Diagnosis. - Ornament on rounded whorls consists of coarse straight axial ribs with fine axial and spiral lines between them. Rounded whorls form a flat coil on the apex, while their diameter increases rapidly. Protoconch is rounded, about $0.5 \mathrm{~mm}$ in size consisting of up to 3 whorls with a basically smooth surface. Aperture of teleoconch with median shallow groove on inner side of inner lip. Next to the flat callus of the inner lip lies an umbilical furrow with a ridge on its outer margin in which the axial ornament of whorls ends.

Differences. - Colubrellopsinae differ from Cassianopsinae by the ornament of the teleoconch. The flattened apical region as found in Colubrellopsis n. gen. may also be noted in Weitschatopsis Frýda, Blodgett \& Stanley, 2003, but the reticulate ornament of axial and spiral ribs as well as less rapid increase in shell width distinguishes the latter genus from Colubrellopsis n. gen.

\section{Genus Colubrellopsis n. gen.}

Type species. - Naticella acuticostata Klipstein, 1843 from the St Cassian Formation, as newly defined below.

Diagnosis. - Apical shell portion appears flatly coiled, while basal shell indicates that whorl diameter increases rapidly. Protoconch consists of rounded whorls with only a weak axial ornament and well impressed sutures. Aperture of teleoconch high with a rounded outer lip and straight inner lip with Neritopsis-like depression and well-developed tubercle-like ends. Flattened callus ribbon ends abruptly at margin of umbilical groove, which has also a sharp corner to the ornamented side of the whorl. Ornament consists of strong, straight axial ribs with fine lines between and even finer spiral lines. Shell composed of thin but solid outer calcitic layer and thick aragonitic layer with bulk formed of crossed lamellar structure.
Name. - The ornament is like that Colubrella while the shell construction and features of the inner lip place the genus near Neritopsis. The name represents a free combination of Colubrella and Neritopsis.

Differences. - Colubrella Koken, 1897 has very similar ornament and a planispiral top to Colubrellopsis, but is also characterized by a planispiral base, which differs from that in the latter genus. The Paleozoic genera Spirina Kaiser, 1898 from the Middle Devonian and Natiria from the Carboniferous may have a similar ornament and shape of the shell, but attain a larger size in fully-grown specimens (Knight 1941, pls 84, 85). Natiria Koninck, 1881 from the Early Carboniferous has a quite similar ornament with larger axial ribs and fine axial line between them, but details regarding the protoconch or the character of the aperture of the teleoconch are not known from that genus.

\section{Colubrellopsis acuticostata (Klipstein, 1843)} Figure 3A-I, K, L

Diagnosis. - Inner lip of aperture bearing the characters of Neritopsis, with on its inner side a median depression and a rounded tooth on either side of that. Narrow callus plate accompanied by a narrow umbilical furrow along its lower part. Ornament of teleoconch consists of larger narrow axial ribs which have a rounded posterior side and a steep front. Between them are many very fine axial lines that are crossed by even finer spiral lines. In second whorl ornament may end and shell becomes smooth or wrinkled. Protoconch is about $0.5 \mathrm{~mm}$ wide consisting of a little more than 3 whorls which overlap each other but display a well recognized suture. Larval whorls are smooth with only few axial lines near the sutures. Final end of larval shell can have a rim or sometimes a fractured margin.

Description. - With three whorls the shell measures about $10 \mathrm{~mm}$ in height and width. The ornament consists of broad, slightly rounded and lamellar axial ribs with a fine pattern of axial and spiral lines in the interspaces. About 15 to 30 ribs are on each whorl, but this ornament may disappear with the second whorl of the teleoconch. The ribs originate in the umbilicus or at the margin of the basal groove in the continuation of the umbilicus. This furrow is ornamented by fine growth lines. Next to it lies the narrow callus plate of the inner lip, which rests on the umbilicus without closing it or covering it. The aperture is of characteristic shape with a straight inner lip and evenly rounded outer lip. On the inner side of the inner lip there are two teeth with a straight inner depression between them.

Differences. - Colubrellopsis acuticostata closely resembles Scalaneritina $\mathrm{n}$. gen. in shape and ornament but the 
axial ribs of its teleoconch ornament do not end in the middle and below the callus cover, but rather terminate on the margin of the umbilical groove. The inner side of the inner lip of Scalaneritina n. gen. is simple and smooth without the characters of Neritopsis as are present in Colubrellopsis acuticostata. The larval whorls of the protoconch of Cassianopsis n. gen. are ornamented and the apertural margin ends with a lobe while the protoconch of Colubrellopsis $\mathrm{n}$. gen. is smooth and has a straight margin in the larval shell.

Remarks. - This species of Colubrellopsis was called Naticella acutecostata by Kittl (1892, pl. 6, figs 22-24) as is documented by a specimen kept at NHMW. However, among the specimens that he described and illustrated not only this species is present, but also Scalaneritina münsteriana (Orbigny, 1849) with very similar ornament and shell shape, but with a different morphology of the inner lip and higher aperture. In the case of the individuals determined by Zardini (1978, pl. 20, figs 5, 6) as Naticella acutecostata, one (fig. 6) belongs to Colubrellopsis, whereas that in his fig. 5 is a Scalaneritina n. gen., since the ribs end at the callus and there is no umbilical furrow. Naticella acutecostata as determined by Zardini (1978) was described by Klipstein (1843) as Naticella acuticostata; Kittl (1892) changed the original spelling into acutecostata.

The genus Colubrella Koken, 1897 has as its diagnostic characters a shell that is planispiral with its whorls barely touching. Its ornament consists of axial ribs of which coarser ones have a number of finer ones intercalated. Colubrella nautiliformis (Broili, 1907) was characterized as having a low spire and a planar coiled shell in which the diameter of the whorl increased rapidly. A secondarily compressed shell called Colubrella (Keration) nautiliformis (Broili) was described by Zardini (1978, pl. 2, fig. 1) and may very well represent Colubrellopsis acuticostata. It was also found at Alpe di Specie (Seelandalpe) as were the individuals studied here. The specimen from the Seiser Alp upon which the species was based by Broili (1907, pl. 7, fig. 9) was obviously reconstructed, since he described it as only partly preserved, especially regarding its apical whorls. The original to Colubrella of Koken (1897) was also crushed. It may be that Colubrella is actually not a planispiral shell, but represents a crushed higher shell, and in that case it might prove to be Colubrellopsis.

Family Fedaiellidae n. fam.

Type genus. - Fedaiella Kittl, 1894.

Diagnosis. - Shell ornament composed only of growth lines and collabral folds. Whorls are rounded and sutures well expressed. The last whorl encompasses most of the earlier shell. Inner lip may extend over much of the umbilical area. Inner side of the inner lip with two folds or teeth in apical and basal positions accompanied by a straight and concave median zone, as in Cassianopsis n. gen. Operculum an ovoid shape with a concentric construction with its nucleus lying close to the middle; two rounded scars present on its inner side. Protoconch a rounded shape with distinct sutures and about 2.5 rounded whorls with little or no ornament on the larval shell. Outer lip has a sinuous or straight margin.

Remarks. - The family is based on the genus Fedaiella as it occurs in the St Cassian Formation near Cortina d'Ampezzo.

Differences. - Regarding shell shape, Fedaiella resembles Hologyra, the latter having a pillar in its umbilical furrow and no teeth and no groove on the inner side of the inner lip. The Fedaiellidae differs from the members of the Hologyrinae in the shape and ornament of the protoconch and of the operculum. The taxa have no sinuous ornament of their larval shell, and their operculum has no triangular base. The shell shape similar to that of Fedaiella is also found in Neritaria which has the inner whorls of its shell dissolved, which is not the case in Fedaiella. In contrast to the concentric outer surface ornament of the Fedaiellidae, the Neritariidae have an operculum as in the Neritidae with a semicircular shape and a nucleus near the side, and with spiral increments of growth.

Remarks. - The species included in the Fedaiellidae n. fam. were originally considered as members of the Naticidae

Figure 3. A - this protoconch of Colubrellopsis acuticostata (Klipstein, 1843) is almost smooth and $0.5 \mathrm{~mm}$ in width and ends with the axial ornament of the teleoconch. $\bullet$ B - Colubrellopsis acuticostata (Klipstein, 1843) showing the change of ornament in the late teleoconch and with a shell width of about $4 \mathrm{~mm}$ (BSPG $2007 \mathrm{XVI}$ 14). $\bullet \mathrm{C}$ - the inner lip of Colubrellopsis acuticostata (Klipstein, 1843) has a flat central groove. This shell is about $5 \mathrm{~mm}$ high. $\bullet \mathrm{D}$ - the protoconch of Colubrellopsis acuticostata (Klipstein, 1843) consist of more than three whorls and is about $0.5 \mathrm{~mm}$ wide. $\bullet \mathrm{E}-$ apical view of Colubrellopsis acuticostata (Klipstein, 1843). Same shell as in Fig. 2D. • F - the callus of the inner lip of Colubrellopsis acuticostata (Klipstein, 1843) with its median depression in the $5 \mathrm{~mm}$ high shell (BSPG 2007 XVI 15). $\bullet \mathrm{G}$ - shell of Colubrellopsis acuticostata (Klipstein, 1843) with the structure of the thin calcitic layer with the growth lines imprinted on the shell surface and crossed lamellar structure below. The shell is about $0.3 \mathrm{~mm}$ thick. $\bullet \mathrm{H}-$ shell of Colubrellopsis acuticostata (Klipstein, 1843) with umbilical groove and about $8 \mathrm{~mm}$ high (BSPG 2007 XVI 16). $・$ I - Colubrellopsis acuticostata (Klipstein, 1843) with a $10 \mathrm{~mm}$ high shell (BSPG 2007 XVI 17). $\bullet$ J convergent shell shape of Ladinaticella costata with a $10 \mathrm{~mm}$ high shell (BSPG 2007 XVI 72). K - Colubrellopsis acuticostata (Klipstein, 1843), same as in Fig. 3L from the back. $\bullet$ L - Colubrellopsis acuticostata (Klipstein, 1843) of Kittl type with a shell about $10 \mathrm{~mm}$ wide. 


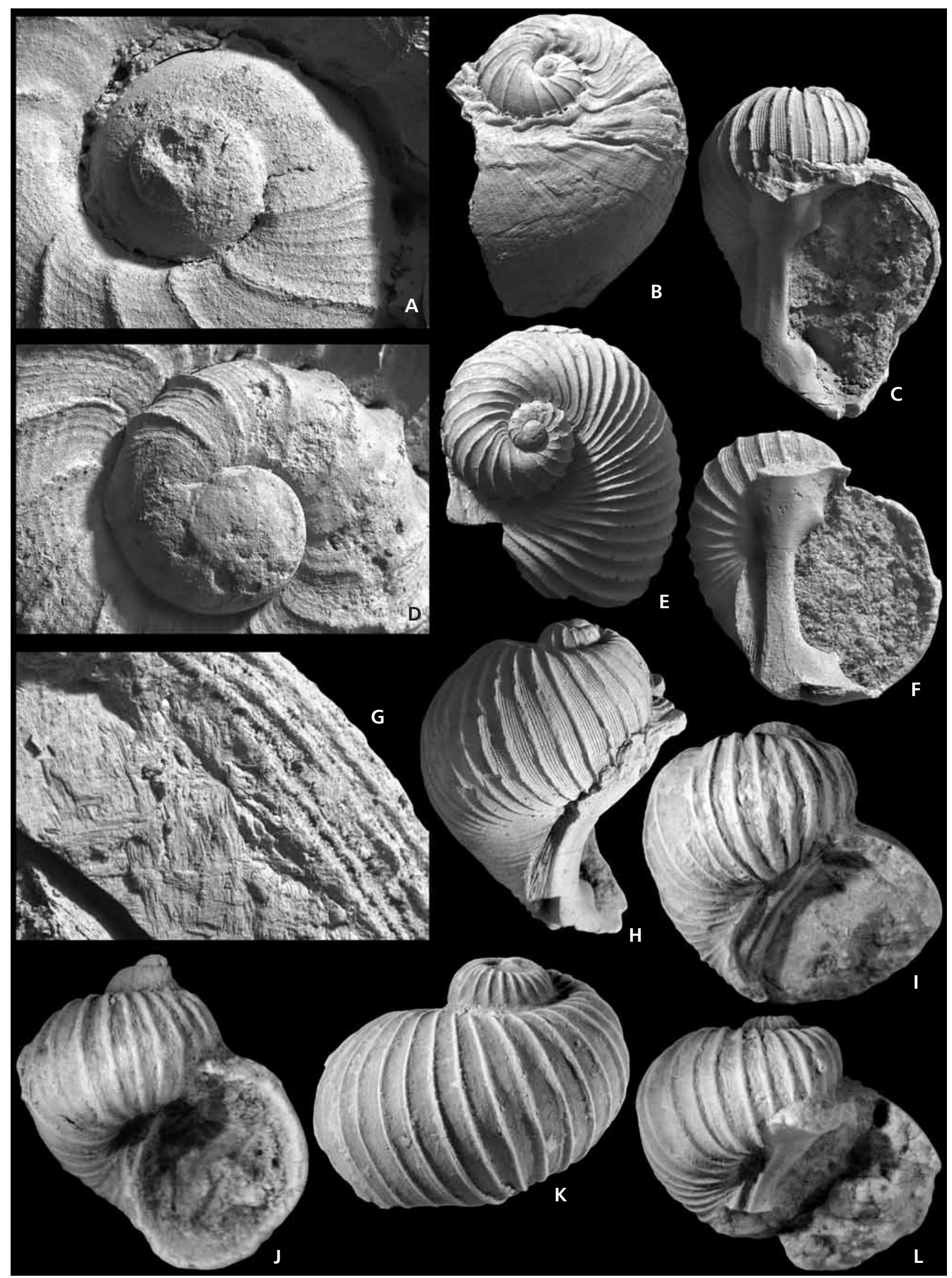


(Münster 1841, Laube 1869). Zittel (1895) recognized that some individuals that now belong in the new family had an operculum of the type found in Neritopsis and therefore he removed them from Natica and its relatives and placed them in Naticopsis. Kittl (1892) discussed the possibility that Naticopsis might represent a precursor to Natica, which can be rejected based on shell structure, operculum shape, and protoconch morphology. Shell composition and shape indicates a relationship with Cassianopsis n. gen. as well as with Colubrellopsis n. gen. The genus Dicosmos Canavari, 1890 had been based on quite undeterminable material, as was discussed by Böhm (1895), while the similar genus Fedaiella has as its type species Fedaiella cuccensis (Mojsisovics, 1873) which is synonymous with $\mathrm{Fe}$ daiella maculosa (Klipstein, 1843) and which earlier has been described as Natica neritacea by Münster (1841). The species Fedaiella neritacea (Münster, 1841) is documented in detail below.

\section{Genus Fedaiella Kittl, 1894}

Type species. - Natica neritacea Münster, 1841 from St Cassian Formation.

Diagnosis. - Genus with characters of the family Fedaiellidae. Smooth and rounded shell may grow to relatively large size. Aperture rounded with inner lip forming a callus ribbon accompanied by an umbilical furrow while the actual umbilicus is covered. Inner side of the inner lip with central depression. Concentric operculum well seen externally with two rounded muscle attachment pits near the inner margin of its inner side. The shell is composed of a thin calcitic outer layer and a thick aragonitic inner layer arranged in crossed lamellar structure.

Remarks. - Wenz (1938-1944, fig. 988) characterized the genus Dicosmos as having a globular shell with a smooth surface and a rounded apex and base. The genus had originally been based on the Ladinian age Dicosmos pulcher Canavari, 1890 from Italy and the holotype is represented by shell that cannot be further determined (Böhm 1895). The specimen may well be related or belong to Fedaiella, but could just as well represent Hologyra or even Neritaria. All these have a similar rounded shape with a smooth surface. Individuals having an operculum with concentric lines on the outer surface were placed in Naticopsis zitteli Kittl, 1892, which is synonymous with Fedaiella neritacea. Zardini (1978, pl. 22, figs 3-5) determined a form Dicosmos maculosa (Klipstein, 1843), which is synonymous with Naticopsis neritacea (Münster, 1841), according to the analysis of Kittl (1892). It has also been called Fedaiella maculosa (= cuccensis Mojsisovics, 1873) when the genus was first proposed by Kittl (1894) from the Marmolata Limestone. This Fedaiella neritacea (= maculosa = cuccensis) can be more clearly recognized and better defined with the material from the St Cassian Formation providing an improved understanding of the type species. Zardini (1978, pl. 21, figs 11a, b, 13a, b) illustrated the typical muscle attachments pits.

\section{Fedaiella neritacea (Münster, 1841)}

Figure 4A-F, M

Diagnosis. - Broadly globular shell with a low but pointed spire. Sutures impressed and ornament consisting of more or less distinct growth increments. Protoconch of rounded low outline with 2.7 apparently smooth whorls. Margin of larval shell has a rounded lobe on its outer lip. Teleoconch of up to five whorls reaching almost $40 \mathrm{~mm}$; aperture rounded with callus of the inner lip accompanied by an umbilical furrow. Inner side of the inner lip has ridges with an angular depression between. Operculum concave and of concentric composition with nucleus displaced a little from the center; two shallow grooves on the inner side.

Remarks. - Zardini (1978, pl. 21, figs 11a, b, 13a, b) illustrated the shallow grooves of the operculum.

Description. - The solid shell has a rounded shape, is usually a little broader than high, has a rapidly increasing

Figure 4. A - protoconch of Fedaiella neritacea (Münster, 1841) about $0.5 \mathrm{~mm}$ wide and showing the teleoconch with initial axial ribs. $\bullet$ B - shell of Fedaiella neritacea (Münster, 1841). Same shell as protoconch shown in Fig. 4A. The shell is about 2 mm in diameter (BSPG 2007 XVI 19). $\bullet$ - the inner lip of Fedaiella neritacea (Münster, 1841) has a central groove on its inner side. The shell is about $2 \mathrm{~mm}$ high. $\bullet \mathrm{D}-$ this operculum still in the aperture of Fedaiella neritacea (Münster, 1841) is of concentric construction. Detail of Fig. 4E, F. • E-side view of Fedaiella neritacea (Münster, 1841) as seen in Fig. 4D (BSPG 2007 XVI 20). • F - specimen of Fedaiella neritacea (Münster, 1841) with the operculum in place, as in Fig. 4D. The shell is about 8 mm in diameter. $\bullet \mathrm{G}$ - the aperture of Fedaiella elongata (Münster, 1841) has a concave inner lip and its callus is accompanied by the umbilical groove. The shell is about $2.5 \mathrm{~mm}$ high (BSPG $2007 \mathrm{XVI} 21$ ). $\bullet \mathrm{H}-$ Fedaiella elongata (Münster, 1841). Shell about 3 mm high (BSPG 2007 XVI 22). • I - this fractured shell of Fedaiella elongata (Münster, 1841) shows the very thin outer calcitic layer and a thick crossed lamellar layer below it. Shell thickness is about $0.1 \mathrm{~mm}$. $\bullet \mathrm{J}-$ Fedaiella elongata (Münster, 1841). Apical view of the shell in Fig. $4 \mathrm{H}$. Shell width about $2.5 \mathrm{~mm}$. $\bullet \mathrm{K}-$ the protoconch of Fedaiella elongata (Münster, 1841) is smooth with a sinuous margin of the larval shell that is about $0.5 \mathrm{~mm}$ wide. $\bullet \mathrm{L}-$ teleoconch has increments of growth in its early part in case of Fedaiella elongata (Münster, 1841). Same shell as shown in detail in Fig. 4K. Shell width about 1.5 mm (BSPG 2007 XVI 23). - M - the apex of Fedaiella neritacea (Münster, 1841) with the characteristic inner lip. The shell is about $11 \mathrm{~mm}$ high (BSPG $2007 \mathrm{XVI} 24$ ). 


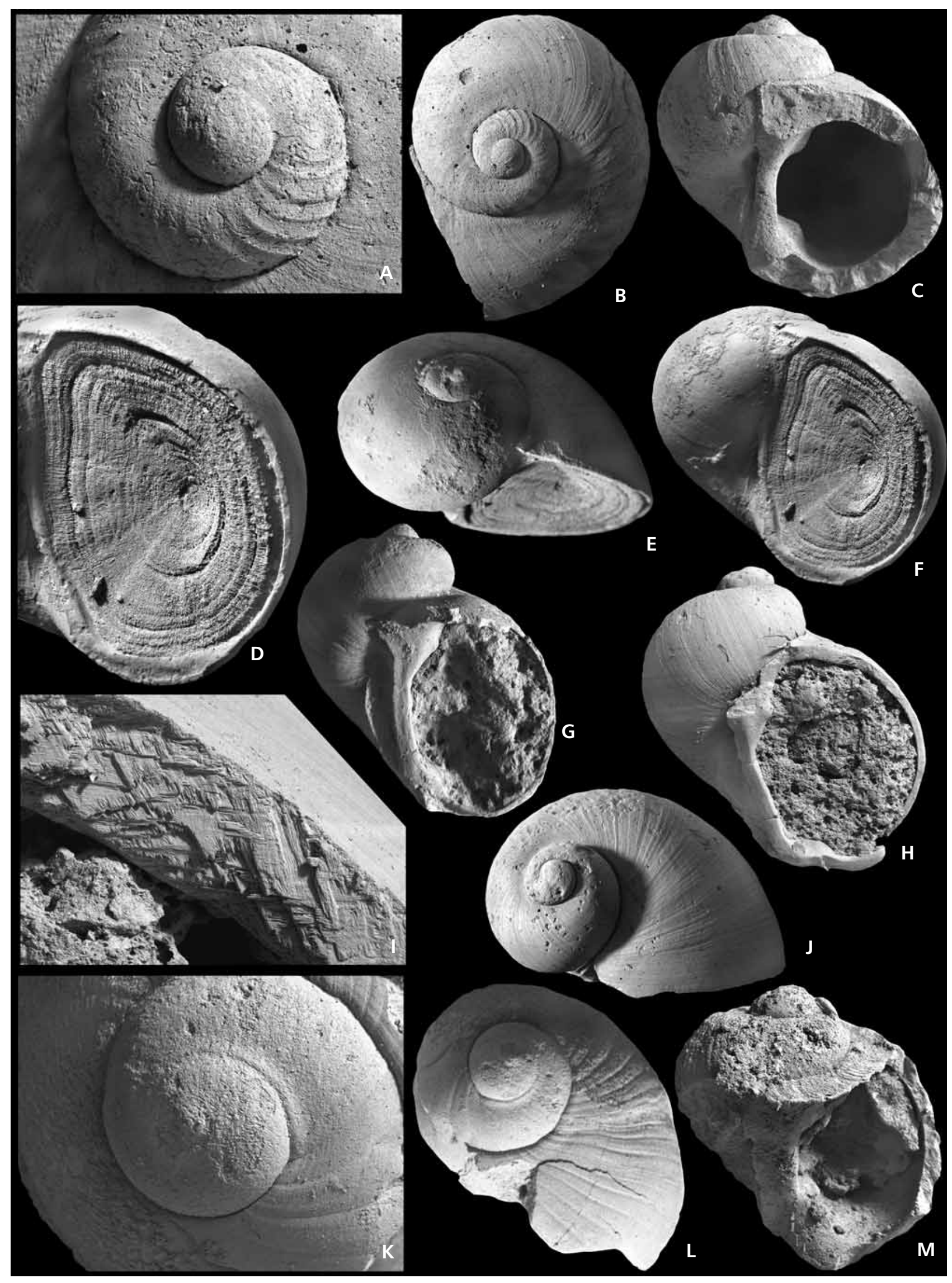


whorl diameter and a large body whorl. The protoconch measures a little less than $0.5 \mathrm{~mm}$. Its embryonic whorl is succeeded by about 1.5 larval whorls, which appear to be smooth. Apertural margin of the larval shell is sinuous with a rounded lobe in the middle of the outer lip. The initial part of the teleoconch attached to the protoconch may be ornamented by some rounded low axial ribs which then become discontinuous. The teleoconch consists of 4-5 rounded whorls with a thickened shell and separated by incised sutures, which are deeper in juvenile than in mature whorls. One shell with 1.25 whorls measures $3.3 \mathrm{~mm}$ in width and $2.9 \mathrm{~mm}$ in height, and a shell of $37 \mathrm{~mm}$ in width is $31 \mathrm{~mm}$ high (Zardini 1978, pl. 22, fig. 5). Color patterns are commonly preserved, mostly represented by elongate dark brown dots of variable size among individuals and also within different zones of growth in the same individual. The aperture is egg-shaped and oblique with straight inner and evenly rounded outer lips. The outer lip is thin at the margin and becomes thick further inward; a ledge is thus developed on the inner margin of the apertural lip. The inner lip forms a flat callus band that covers the umbilicus. Tubercles accompany the central depression of the inner side on either side. The inner walls of the shell are not dissolved. This is the case in juvenile shells, as well as in a fully-grown shell of more than $30 \mathrm{~mm}$ in diameter.

An operculum found in place closing the shell is slightly convex and of oval shape with its surface covered by concentric growth lines. Growth increments consist of calcitic needle-like crystallites arranged so that they point toward the outside of the operculum. The slightly eccentric nucleus lies closer to the outer lip than to the inner lip and two depressions diverge from it running to the corners of the operculum. The inner side of the operculum has a thickened margin and two low depressions, which are divided by a central swelling.

Differences. - The shell shape resembles that of Hologyra cassiana, which differs in the characteristic column-like ridge on the umbilical furrow, and the sinuous ornament of its larval shell. In addition, the operculum in Fedaiella neritacea has a triangular base.

Remarks. - Klipstein (1843) named Natica maculosa, which, according to Kittl (1892, pl. 6, figs 29-32, pl. 7, fig. 1), should be placed into the genus Naticopsis, and actually represents the same species as Natica neritacea Münster, 1841. A problem with this interpretation is the absence of the specimen on which Münster (1841, pl. 10, fig. 2) based his species, which apparently has been lost. Kittl (1892) used part of the type material of Natica maculosa to describe his Naticopsis neritacea and most later authors accepted that suggestion, as is also done here. Tichy (1980, pl. 3, fig. 3) in his description of color patterns used the figure of Klipstein (1843) and determined it as $D i$ cosmos maculosus (Klipstein, 1843), and next to it in Tichy (1980, pl. 3, fig. 2) named an individual Naticopsis (N.) neritacea (Münster, 1841) based on a figure from Kittl (1892, pl. 6, figs 29-32), apparently interpreting these two as different species. Broili (1907, pl. 8, figs 17-19) suggested that in the case of Naticopsis maculosa from St Cassian there might be a depression below the suture of the last whorl. However, such a depression may or may not appear in different individuals of the same species.

Blaschke (1905, pl. 20, fig. 1) recognized the form Fedaiella neritacea as Dicosmos (Fedaiella?) seisiensis (aff. Dicosmos declivis) n. f. from the Seiser Alp, considering it a local variety of Naticopsis maculosa. In the case of Dicosmos applanatus Kutassy, 1937, the author also used as a characteristic the flattening of the subsutural ribbon to differentiate it from Naticopsis maculosa. Actually this species is probably identical with Fedaiella neritacea. It was determined as Dicosmos maculosus by Leonardi \& Fiscon (1959, pl. 2, figs 24, 25, pl. 3, fig. 1) and Zardini (1978, pl. 20, figs 9, 10, pl. 22, fig. 5; 1985, pl. 7, figs 2, 3), but none of the illustrated individuals show the inner folds on the inner lip of the aperture. The operculum was documented as belonging to Neritopsis by Zardini (1978, pl. 21, fig. 13; 1985, pl. 4, fig. 9).

\section{Fedaiella elongata (Münster, 1841)}

Figure 4G-L

Diagnosis. - Shell higher than wide up to about $11 \mathrm{~mm}$ with a pointed spire. Whorls rounded. Inner side of the inner lip has a rectangular median depression. Oval aperture with a narrow apical portion; thick callus of the inner lip covers the umbilical region. Narrow callus band at the base and wide at the apical side of aperture. Rounded protoconch consists of about 2.5 whorls with the suture of the last whorl quite distinct; larval whorls have a straight outer lip at the aperture.

Remarks. - The characters of the inner lip and general shell features resemble those of Fedaiella neritacea.

Description. - The shell is short, Lymnaea-shaped with four whorls in the teleoconch. The ornament consists of simple collabral growth increments, some more strongly developed than others. The callus of the inner lip broadens towards its middle and forms a pad, accompanied by a groove basal to it. This depression has growth increments of the former margins, of which the outermost forms a sharp edge to the whorl. This edge is continuous into the evenly rounded outer lip of the semicircular aperture. On the inner side of the inner lip two folds are developed of which the apical fold is inclined and the basal fold is pointed. A shell 
with 2.7 whorls in the teleoconch is $3.5 \mathrm{~mm}$ wide and $4 \mathrm{~mm}$ high. It has an angular groove between the tubercles on the inner lip, which is well developed in juveniles but becomes shallow and indistinct in more mature shells with some 4 whorls in the teleoconch and typically $11 \mathrm{~mm}$ high by $10 \mathrm{~mm}$ wide. The outer calcitic layer of the shell is very thin and the shell surface is smooth.

The protoconch measuring about $0.5 \mathrm{~mm}$ in diameter has a globular embryonic whorl that is covered to a large extent by the first larval whorl. In the larval part of the protoconch whorls increase in width and the suture becomes more distinct. The margin of the larval shell is straight. The changeover to the teleoconch is indicated by coarser growth lines. The ornament is not well preserved but seems to consist of fine and low axial ribs.

Differences. - The two folds on the inner side of the inner lip of the aperture resemble those found in Fedaiella neritacea, but the high spire differentiates them from one another.

Remarks. - The species exhibits its lower inclined ridge on the inner side of the inner lip as illustrated by Zardini (1978, pl. 19, fig. 15), determined by him as Naticopsis cassiana. The description of the species presented by Kittl (1892, pl. 7, figs 3, 4) is not conclusive with the exception of his remarks about the callus of the inner lip with its thickened upper part and a depression below it, that is characteristic of the specimens studied here. The holotype of Naticopsis elongata var. chromatica Kittl, 1892 coincides its morphology with Fedaiella elongata. It has a similar size and shape, but belongs to a relatively worn specimen, so that the features of the callus of the inner lip are not well preserved. The specimen illustrated by Kittl (1892, pl. 7, figs 3, 4) and determined as Naticopsis subelongata Orbigny has indications of the folds or tubercles on the inner side of their inner lip, but the shells appear to be too short to fit with Fedaiella elongata. A better fitting shell shape and ornament is preserved in Naticopsis gaderana Kittl, 1892 as seen in the holotype in the collection at NHMW, which has an egg-shaped shell but does not expose the inner lip (Kittl 1892, pl. 7, figs 9, 10). Another individual determined as Naticopsis gaderana by Kittl (1892) has folds on its inner lip. It is quite possible that the species determined as Naticopsis limnaeiforme (Laube, 1869) is Fedaiella elongata as well (Kittl 1892, pl. 7, fig. 8). Neither the original description provided by Laube (1869, pl. 22, fig. 3), nor that of Kittl (1892, pl. 7, fig. 8) is conclusive.

Böhm (1895, figs 33, 34) described Fedaiella cuccensis (Mojsosovics, 1873) as well as Fedaiella bennecki Böhm, 1895 and clearly documented the two teeth on the inner side of the inner lip of their aperture connected to an angular depression as in Neritopsis.
Family Delphinulopsidae Blodgett, Frýda \& Stanley, 2001

Diagnosis. - Shell diameter increases rapidly and later whorls may discontinue the earlier tight coiling mode of the shell; whorls angular. Aperture increases in size until an almost limpet-like form is achieved with straight inner and a well-rounded outer lip. Inner side of the inner lip is smooth. Ornament consists of spiral keels or rows of tubercles or spines. Outer shell layer thin and calcitic and underlain by a thick aragonitic layer in crossed lamellar structure.

Remarks. - The family is based on Delphinulopsis Laube, 1868 and was created to find a place for some Triassic species with a goat-horn-like shell resembling that of Delphinulopsis binodosa from the St Cassian Formation. Blodgett et al. (2001) suggested that the taxon should also include species belonging to Paradelphinulopsis Blodgett, Frýda \& Stanley, 2001 from the Late Triassic of western North America.

Subfamily Delphinulopsinae Blodgett, Frýda \& Stanley, 2001

Diagnosis. - Inner lip expanded to form a concave callus; whorls have spiral ribs with tubercles or spines.

Remarks. - The subfamily has the character of the genus Delphinulopsis from the St Cassian Formation. Here the genus Delphinulopsis is characteristic and a new genus Schwardtopsis n. gen. (see below) is included because it closely resembles young stages of Delphinulopsis binodosus but with its shell attaining a larger size. All are from the St Cassian Formation.

\section{Genus Delphinulopsis Laube, 1868}

Type species. - The genus is based on Delphinulopsis binodosa (Münster, 1841) from the St Cassian Formation.

Diagnosis. - Shell shaped like the horn of a goat with whorls of the teleoconch detaching from each other, but remaining in a spiral coil. A concave callus plate of the inner lip increases in size as whorls become less tightly coiled. Ornament consists of four spiral rows of large tubercles of which the basal one is covered by the succeeding whorl.

Remarks. - The genus has been considered to be a synonym of Fossariopsis by Wenz (1938-1944, fig. 1006) (see there). Delphinulopsis has its early whorls similar to Schwardtopsis n. gen. but differs from the latter by its more openly coiled shell with a characteristic wide, flattened cal- 
lus on the inner lip. In his description of Delphinulopsis binodosa Kittl (1892, pl. 8, figs 36-43) included also specimens here referred to Schwardtopsis n. gen. with a much smaller callus on the inner lip.

\section{Delphinulopsis binodosa (Münster, 1841) Figure 5A-E}

Diagnosis. - The species has the characters of the genus. Angular shell with two tubercle-bearing keels with whorls detaching from each other in the mature shell. Callus plate of the inner lip wide and concave. Protoconch is globular.

Description. - The shell is up to $18 \mathrm{~mm}$ high and wide, has a flat concave inner lip (Laube 1869) and consists of a few whorls that detach. There are three whorls in the teleoconch. The coiling mode is quite variable since the late whorls detach somewhat from the earlier ones. The degree of detachment differs among individuals. The ornament consists of four spiral keels, with the uppermost keel near the suture, the next on the periphery, the third at the corner to the base and the fourth on the base. The successive whorls do not cover the upper three keels while the row of tubercles on the base becomes hidden. The main keels on the corners may form hollow spines in the third whorl of the teleoconch. While the first whorls form a high spire, the last whorl coils almost in a plane and increases greatly in width. A shell with 1.5 whorls of the teleoconch is a little more than $2 \mathrm{~mm}$ wide and high. The largest shell studied is about $18 \mathrm{~mm}$ wide and high with a corroded apex. The body whorl has the four keels separated from each other by flat to concave spaces and the keels carry spines. Coarse growth lines are commonly developed as wrinkled lamellae that are inclined backwards from the suture. The aperture is semicircular with a straight inner lip that extends into a very large plate-like callus with growth-line pattern. This plate is concave and curved in the same way as the openly coiled shell. The outer margin of the callus plate is accompanied by a groove that begins in the umbilical slit. The inner side of the inner lip is smooth and simple. Inner walls of the whorls are not dissolved.
Differences. - The shell of Delphinulopsis binodosa begins to detach its whorls from one other while those of Schwardtopsis münsteri remain in contact and, in addition, the latter never develops a wide callus plate.

Remarks. - The species was originally determined as Pleurotomaria binodosa Münster, 1841. It is quite variable in shape and changes its mode of shell coiling during ontogeny. Laube $(1869, \mathrm{pl} .33$, figs 1,5$)$ referred specimens to Delphinulopsis arietina and also Delphinulopsis binodosa. Kittl (1892, pl. 8, figs 36-43; 1894, pl. 2, fig. 2) described it as Delphinulopsis binodosa, as did Broili (1907, pl. 7, figs 32, 34). In contrast, Wenz (1938-1944, fig. 106) called it Fossariopsis binodosa, and that name was also applied to it by Leonardi \& Fiscon (1959). Zardini (1978, pl. 24, fig. 1) used Delphinulopsis and also recognized Delphinulopsis laubei but Kittl's taxon (1892, pl. 8, fig. 44) simply represents a juvenile shell of Delphinulopsis binodosa with only two peripheral keels developed. Zardini (1978, pl. 23, figs 8,10 ) also illustrated Delphinulopsis münsteri, here referred to Schwardtopsis. In this he followed Kittl (1892, pl. 8, figs 39-44), who also considered the two taxa as the same species illustrating Delphinulopsis binodosa in pl. 8, figs 3-44 and in pl. 8, fig. 37 a specimen here called Schwardtopsis münsteri. Yin \& Yochelson (1983, fig. 3H, $\mathrm{K}, \mathrm{R}$ ) determined a species from the Triassic of China as Delphinulopsis binodosa, describing the inner lip of Delphinulopsis as occupying half of the inner part of aperture, which does not distinguish it from Schwardtopsis.

\section{Genus Schwardtopsis n. gen.}

Type species. - The new genus is based on Fossariopsis münsteri (Klipstein, 1843) as described by Laube (1869) from the St Cassian Formation. A characteristic shell of Schwardtopsis münsteri is illustrated by Zardini (1978, pl. 23 , figs 8,10 ) and was determined by him as Delphinulopsis binodosus.

Diagnosis. - High conical shell with ornament consisting of two rows of tubercles; callus of the inner lip is narrow.

Figure 5. A - shell of Delphinulopsis binodosa (Münster, 1841) with its screw-like spire and large concave callus of the inner lip. The shell is about $15 \mathrm{~mm}$ high. $\bullet \mathrm{B}$ - the same shell as in Fig. 5A with ornament of gutter like spines (BSPG 2007 XVI 25). $\bullet$ C - juvenile shell of Delphinulopsis binodosa (Münster, 1841), which is about $3 \mathrm{~mm}$ high (BSPG 2007 XVI 26). $・$ D - shell of Delphinulopsis binodosa (Münster, 1841) with a semicircular aperture. Shell about $6 \mathrm{~mm}$ high. $\bullet \mathrm{E}$ - the same shell as in Fig. 5D seen from behind with open-coiling mode (BSPG 2007 XVI 27). $・$ F - Schwardtopsis münsteri (Klipstein, 1843) with a slender shell and normal coiling. The shell is almost 5 mm high (BSPG 2007 XVI 28). $\bullet$ G - the shell wall of Schwardtopsis münsteri (Klipstein, 1843) exhibits a thin calcitic outer layer (right side) and a thick inner crossed lamellar layer with a prismatic layer on the inside. The shell is $0.5 \mathrm{~mm}$ thick. $\bullet \mathrm{H}$ - this juvenile shell of Schwardtopsis münsteri (Klipstein, 1843) is about $2 \mathrm{~mm}$ wide. $\bullet \mathrm{I}-$ the narrow callus of the inner lip distinguishes Schwardtopsis münsteri (Klipstein, 1843). Shell is $1.8 \mathrm{~mm}$ high (BSPG 2007 XVI 29). • J - the shell of Platychilina pustulosa (Münster, 1841) is almost limpet-like (BSPG 2007 XVI 30). $\bullet \mathrm{K}$ - the same shell as in Fig. 5J in apical view. The shell is about $12 \mathrm{~mm}$ wide. $\bullet \mathrm{L}-$ the same shell as in Fig. 5J and $\mathrm{K}$ seen from the backside showing three rows of tubercles. $\bullet \mathrm{M}-$ more juvenile shell of Platychilina pustulosa (Münster, 1841). The shell is 9 mm wide (BSPG 2007 XVI 31). • N - the same shell as in Fig. 5M seen from behind. 


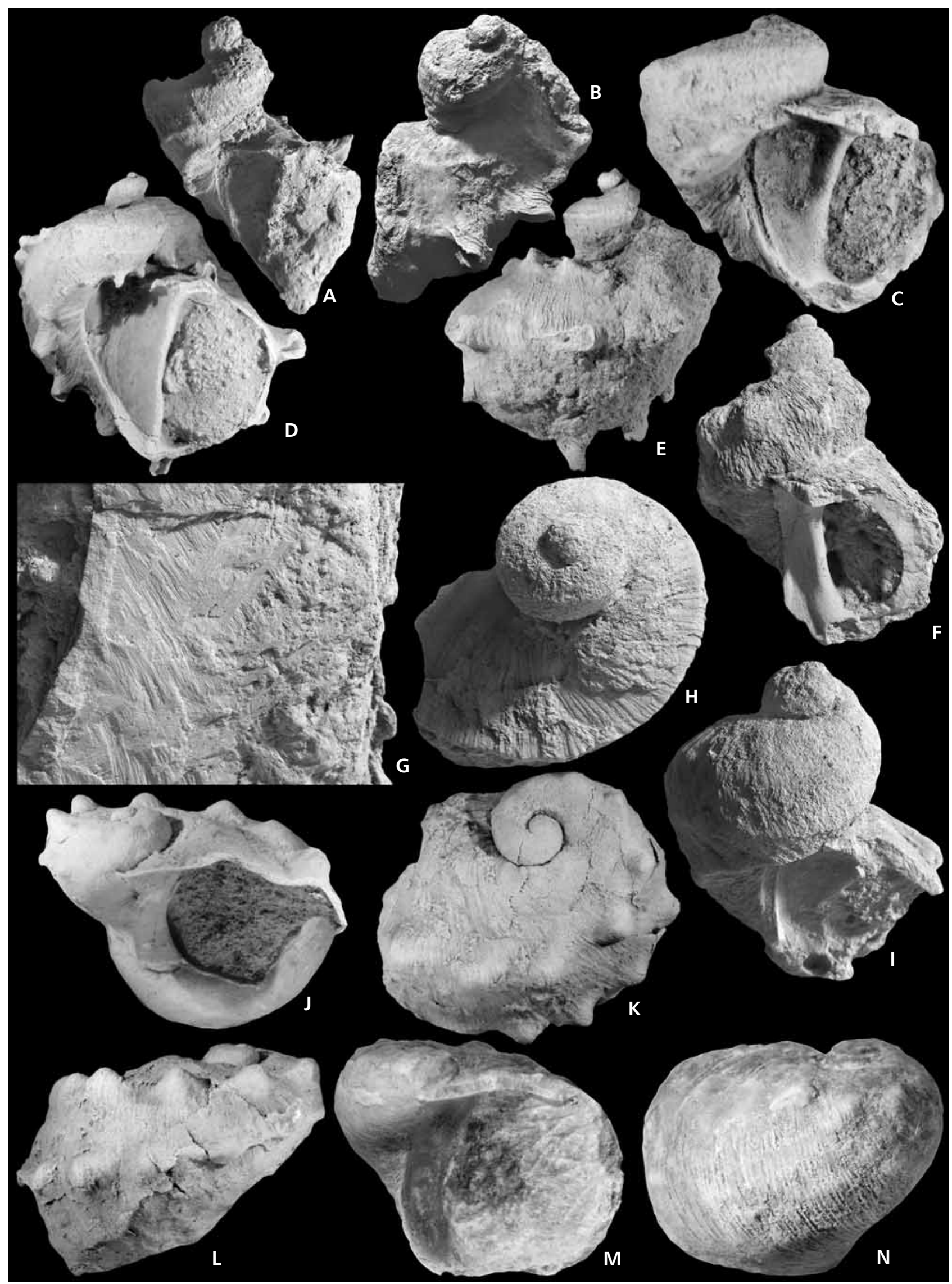


The body whorl may have a third spiral rib on the base. Shell composition is a thin outer calcitic layer and a thick inner crossed lamellar layer.

Differences. - Schwardtopsis münsteri differs from Delphinulopsis binodosus by its narrow inner lip callus and the high spire in which the whorls do not detach from each other during late stages of growth. The early juvenile shell of Delphinulopsis binodosa is very similar in its elongate coiled shape and the two spiral ribs of its ornament, but it develops a broad callus on the inner lip, develops two more spiral ribs later on, while in Schwardtopsis münsteri the inner lip is narrow from the beginning and remains that way throughout growth, and differs additionally in having the number of ribs increasing only to three.

Name. - The genus is named for Annette Schwardt. She began to assemble some of the data on the Neritimorpha of the St Cassian Formation and recognized that the genus called in her honor as distinct from Delphinulopsis.

\section{Schwardtopsis münsteri (Klipstein, 1843)}

Figure 5F-I

Diagnosis. - Shell higher than wide with more than three whorls up to $18 \mathrm{~mm}$ high. Whorls flattened on the sides and spiral ribs present on the corners to the shoulder and to the base and on the base. Aperture ovoid in outline with a simple thickened and grooved callus of the inner lip that covers the umbilicus. From the umbilicus a furrow accompanies the inner lip and its margin is formed by basal spiral rib.

Description. - The conical shell is higher than wide and has an ornament of two keels with tubercles, but it may also carry spines on the upper and lower corners of the whorls, which become hollow gutter-like in the last whorl. A row of tubercles or short spines on the base is covered by the succeeding whorls. The shell is thick and when obtaining 2.5 whorls the teleoconch measures about $4.5 \mathrm{~mm}$ wide by $6 \mathrm{~mm}$ high. The largest shell known is about $18 \mathrm{~mm}$ high and $15 \mathrm{~mm}$ wide with a final whorl with four rows of nodules of which those in the second row are actually hollow spines. The whorl in the peripheral keel has 9-10 spines. The sides are flattened and concave. A smaller basal spiral row surrounds the umbilical region, with the umbilicus closed by the callus of the inner lip. Growth lines are straight and inclined in a posterior direction. The outer thin calcitic layer has fine lamellar growth increments, which can be somewhat undulating. The bulk of the shell consists of aragonitic material with crossed lamellar structure. The aperture is relatively small and semicircular with a simple outer lip and an inner lip with a thickened margin and a smooth columellar edge. The inner walls of the shell are not dissolved.
Differences. - Schwardtopsis münsteri differs from Delphinulopsis binodosa in its narrower inner lip that forms no wide septum, and the pointed high shell shape. A shell from the collection at NHMW was documented and determined as Fossariopsis münsteri (Klipstein) by Laube (1869); despite being quite corroded, it displays the characters of the species and genus. In Platychilina pustulosa the shell is lower and whorls more rounded.

Remarks. - Schwardtopsis münsteri was documented by Zardini (1978, pl. 23, figs 8, 10) as Delphinulopsis binodosa. Yin \& Yochelson (1983, fig. 3D) probably also had a specimen of Schwardtopsis, but according to their description it is closer to Delphinulopsis.

Subfamily Platychilininae n. subfam.

Type genus. - The subfamily is based on Platychilina, and includes also Marmolatella. Both of these genera are recognized from the St Cassian Formation.

Diagnosis. - Shell diameter increases rapidly and ornament consists of fine collabral lamellae of the outer calcitic layer to which nodular spiral keels or spiral rows of nodes or hollow spines may be added. Shell walls are not dissolved in the interior of the protoconch or teleoconch. Protoconch resembles that of the Cassianopsinae and Colubrellopsinae in size and shape. Operculum unknown. Inner side of the inner lip is simple and straight without teeth or a groove.

Remarks. - The protoconch of the Platychilininae is rounded and consists of several whorls and has a size of $0.5 \mathrm{~mm}$, but its ornament is not well preserved. The shell of the teleoconch consists of an outer calcitic layer and an inner aragonitic layer with crossed lamellar structure as is found in most of the Neritimorpha of the St Cassian Formation. The shape of the inner lip, with a broad and simple callus band, places the subfamily near the Palaeonaricidae (see below), which has similar features. The shell shape may indicate that platychilininids are related to the Pseudorthonychiidae Bandel \& Frýda, 1999, which differs in having a very characteristic protoconch and a thick outer calcitic layer in the teleoconch.

\section{Genus Platychilina Koken, 1892}

Type species. - The genus was based on a species from the Raibler beds of the Schlern Plateau, determined as Platychilina wöhrmanni Koken, 1892 and documented by Wenz (1938-1944, fig. 1005). However, as suggested as a possibility by Koken (1892), Platychilina wöhrmanni is closely 
similar or maybe even be the same species as that described earlier as Capulus pustulosus Münster, 1841 from the $\mathrm{St}$ Cassian Formation, which is here suggested to represent the type for the genus.

Diagnosis. - Lowly coiled shell with the juvenile part being stair-like and having a tubercle-bearing corner. Subsequently, the shell becomes ear-like with more rounded whorls and ornament consisting of several rows of coarse pustules and ridges. Aperture has a simple inner lip with a flattened ribbon-like callus.

Remarks. - The shell of the holotype of the type species consists of about 3.5 whorls and measures about $20 \mathrm{~mm}$ in diameter (Koken 1892, pl. 11, figs 5-8). Its shell is a little more compact than a shell of about the same size from probably the same or a very closely related species that was documented by Zardini (1978, pl. 23, fig. 11a, b) and determined by him as Delphinulosis binodosus. Koken (1892) suggested that his species as well as Fossariopsis cainalloi (Stoppani, 1860) and Capulus pustulosus might represent one and the same species. The material studied here indicates that this assumption is correct and these species probably represent just varieties and growth stages of the same species.

\section{Platychilina pustulosa Münster, 1841}

\section{Figure 5J-N}

Diagnosis. - Juvenile whorls of the shell have a flattened apical side with an edge ornamented by coarse tubercles. Subsequently, the whorls are more rounded with a rapid increase in shell diameter. Ornament consists of two or three spiral rows of irregular tubercles. Aperture is rounded and wide with a straight inner lip that forms a flat narrow callus band.

Description. - A shell which is $10 \mathrm{~mm}$ wide by $8 \mathrm{~mm}$ high consists of three whorls in the teleoconch. A row of tubercles is present on the corner and another row located on the side of the first whorl; later even three rows of large rounded tubercles form the ornament. Growth increments are fine, a little irregular in their orientation, and reflect the added sheets of the outer calcitic layer of the shell. After the juvenile stage the shell becomes more openly coiled and whorls more rounded. One shell of $18 \mathrm{~mm}$ wide is $10 \mathrm{~mm}$ high, its aperture is large with a rounded outer lip and weakly concave inner lip that forms a flat callus ribbon. The juvenile shell has a somewhat square outline with an angular upper corner and an aperture which is large and rounded. This stage has been described as Dephinulopsis cainalloi by Kittl (1892). The fully-grown stage is illustrated by Zardini (1978, pl. 23, fig. 11) as Dephinulopsis binodosa. The inner lip is weakly concave and forms a broad ribbon of the callus from base to top. It covers the umbilicus which lies high up. The inner side of the inner lip is smooth. The protoconch is rounded, with overlapping whorls, and measures about $0.5 \mathrm{~mm}$ in width. The ornament consists of delicate axial ribs, which appear to be collabral but which are not well preserved.

Differences. - The holotype is close to the Cassian species described as Delphinulopsis binodosus by Zardini (1978, pl. 23, fig. 11a, b) which represents a large shell. It differs from Delphinulopsis in having a lower shell and relatively narrow callus plate and an ornament consisting of rounded tubercles. Marmolatella (Haliotimorpha) Blaschke, 1905 has only one row of hollow tubercles at its edge, while two or three are present in Platychilina pustulosa, and in addition has whorls which are more rounded. Kittl (1892) did not correctly describe Capulus pustulosus of Laube (1869), which is preserved in the NHMW collection. The apex is low, and the three whorls increase rapidly in size. As noted by Broili (1907), the juvenile shell of Platychilina pustulosa closely resembles Platychilina cainalloi.

Remarks. - A specimen of Delphinulopsis cf. cainalloi from Alpe di Specie, illustrated by Kittl (1892, pl. 9, fig. 1), was studied from the NHMW collections. It closely resembles Platychilina cainalloi described by Zardini (1978, pl. 23, fig. 7), with both specimens coming from the same locality. Kittl (1892, pl. 9, fig. 1) suggested that Platychilina cainalloi has a slightly higher spire than Pileopsis pustulosus Münster, 1841. The diameter of the whorls of the specimen which Kittl (1892) determined as Delphinulopsis pustulosus are almost circular, and its ornament consists of two spiral rows of large rounded nodules. The different shells belonging to the same species were considered to represent different species by Kittl (1892, pl. 5, figs 1, 2, pl. 9, fig. 2), a fact noted by Broili (1907). Platychilina wöhrmanni represents a synonym of Platychilina pustulosa (Broili, 1907). Böhm (1895) assumed that Platychilina wöhrmanni has the inner whorls of its shell dissolved, which is not the case. Leonardi \& Fiscon (1959) determined Platychilina pustulosa in the same way as is carried out here. Knight et al. (1960, fig. 1822a, b) illustrated the juvenile Platychilina as Seisia Kutassy, 1934 among the Neritopsinae, with the illustration and description very similar to Platychilina (Knight et al. 1960, fig. 183, 6a, b), but they placed the latter among the Neritinae.

\section{Genus Marmolatella Kittl, 1894}

Type species. - The genus is based on Ostrea stomatia Stoppani, 1858 from the Esino Limestone of the Italian Alps, and it has not been recorded from the St Cassian Formation (Kittl 1892). 
Diagnosis. - Shell ear-like in shape with a rounded to flattened apex and large body whorl. Shell surface is smooth aside from increments of growth. Aperture is oval to round with the callus of outer and inner lips connected and smooth.

Remarks. - Haliotimorpha Blaschke, 1905 was considered to represent a subgenus of Marmolatella by Broili (1907, pl. 9, fig. 16-18). Knight et al. (1960, figs 180A, 1a, b, 181, $9 \mathrm{a}, \mathrm{b})$ considered both to represent different genera of the subfamily Naticopsinae, family Neritopsidae, even though both are characterized by an ear-like shell that has its whorls coiled to the side. Their juvenile shell is almost flat with its apex low in the early whorls of the teleoconch, but later becoming limpet-shaped. In the case of Haliotimorpha the peripheral side develops a row of nodules or open spines. Wenz (1938-1944, fig. 985) figured the apertural structure; the inner lip of the aperture is formed by a straight and wide ribbon of callus. However, Haliotimorpha dieneri (Blaschke, 1905) from the Seiser Alp, which was clearly a large and limpet-like species when fully-grown, quite evidently was equivalent to Marmolatella (Marmolatella) Kittl, 1892 in its early ontogenetic shell. Neither growth stage has the characteristic depression on the inner lip as is at least partly characteristic to the family Neritopsidae in the definition that was presented by Knight et al. (1960) for that taxon. They regarded Marmolatella as a subgenus of Naticopsis. This decision that was accepted by Jeffery et al. (1994) who described two species known only by teleoconch shape from the Carboniferous of Arkansas as belonginng to Marmolatella. However, this is unlikely since Naticopsis has a type species that lived in the Early Carboniferous and thus it may not be very closely related to the Triassic species of Marmolatella that lived around 100 million years later.

\section{Marmolatella fenestrata (Laube, 1869) Figure 6A-F}

Diagnosis. - Horn-shaped shell with low spire. Ornament consists of lamellar collabral ribs and fine spiral lines. Pro- toconch rounded consisting of 2.5 whorls with a distinct suture and sinuous margin on the outer lip of the larval shell.

Remarks. - The species was originally described as Capulus fenestratus Laube, 1869 and later determined as Naticella anomala Kittl, 1892 from the St Cassian Formation (Kittl 1892, pl. 9, fig. 7).

Description. - The shell shape resembles that of the bivalve Gryphaea, with a low openly coiled whorl. One whorl of the teleoconch is about $11 \mathrm{~mm}$ wide and $7 \mathrm{~mm}$ high. Ornament consists of growth lamellae of the outer, calcitic layer of the shell, transected by very fine spiral lines producing a fenestrate pattern. The aperture has simple, semi-circular shape and is very wide. The inner lip is almost straight and extended to form a flattened simple shelf of the callus. It covers the umbilical region. The protoconch is tightly coiled, consists of nearly 2.5 whorls that form a helical spire. The suture of the larval whorls is distinct, but the ornament of the whorls is not preserved in detail. The margin of the outer lip of the aperture of the fully-grown larval shell appears to have a wide lobe and a marginal low saddle. Shell composition consists of a solid but thin outer calcitic layer into which the dense growth increments as well as the fine spiral lines are imprinted and a thick inner aragonitic layer composed of crossed lamellar structure with a smooth contact to the outer layer.

Remarks. - The shell is lowly coiled and has a depressed apical area, but is not sinistral as assumed by Kittl (1892) in the case of Capulus(?) fenestratus Laube, 1869 or Naticella(?) anomala Kittl, 1892 (Kittl 1892, pl. 9, figs 7, 8). The holotype of Naticella anomala Kittl, 1892 from NHMW belongs to this species. The same species has been illustrated by Zardini (1978, pl. 24, fig. 2a-c) and was determined by him as Delphinulopis pustulosa. A poorly preserved small individual of Marmolatella fenestrata was illustrated by Kittl (1892, pl. 9, fig. 8). He placed two quite

Figure 6. A - apical view of Marmolatella fenestrata (Laube, 1869). Shell $4.5 \mathrm{~mm}$ wide (BSPG 2007 XVI 32). • B - apical view of Marmolatella fenestrata (Laube, 1869). Shell about $2 \mathrm{~mm}$ wide. Fig. 6C is a detailed view (BSPG 2007 XVI 33). $\bullet$ C - the protoconch of Marmolatella fenestrata (Laube, 1869) with rounded whorls and a simple margin. Width of protoconch about $0.5 \mathrm{~mm} \cdot \bullet \mathrm{D}$ - apertural view of Marmolatella fenestrata (Laube, 1869). Shell about $6 \mathrm{~mm}$ high (BSPG 2007 XVI 34). $\bullet \mathrm{E}$ - somewhat recrystallized shell of Marmolatella fenestrata (Laube, 1869) broken to show the relatively thin outer calcitic layer (upper part) and thick crossed lamellar layer below. The shell is about $0.2 \mathrm{~mm}$ thick. • F - apertural view of Palaeonarica concentrica (Münster, 1841). Shell about $4 \mathrm{~mm}$ wide (BSPG 2007 XVI 35). $\bullet \mathrm{G}$ - apical view of Palaeonarica concentrica (Münster, 1841). Shell about $4 \mathrm{~mm}$ wide. $\bullet \mathrm{H}$ - juvenile shell of Palaeonarica pyrulaeformis (Klipstein, 1843) which is $4 \mathrm{~mm}$ in height (BSPG 2007 XVI 36). - I - the inner lip of the aperture of Palaeonarica pyrulaeformis (Klipstein, 1843) is simple and evenly smooth. The shell is about $10 \mathrm{~mm}$ high (BSPG 2007 XVI 37). • J - shell structure of Palaeonarica pyrulaeformis (Klipstein, 1843) with the calcitic layer continuous and thin (upper part) underlain by the thick crossed lamellar layer. The visible shell is about $0.1 \mathrm{~mm}$ thick. $\bullet \mathrm{K}$ - Palaeonarica pyrulaeformis (Klipstein, 1843) seen from the side. Shell about $5 \mathrm{~mm}$ wide. (BSPG 2007 XVI 38). $\bullet \mathrm{L}$ - apical view of Palaeonarica pyrulaeformis (Klipstein, 1843) showing the protoconch with rounded whorls. The shell is about $1.8 \mathrm{~mm}$ wide (BSPG 2007 XVI 39). $\bullet \mathrm{M}$ - specimen of Palaeonarica pyrulaeformis (Klipstein, 1843) showing smooth inner lip. Shell about $10 \mathrm{~mm}$ wide (BSPG 2007 XVI 40). 


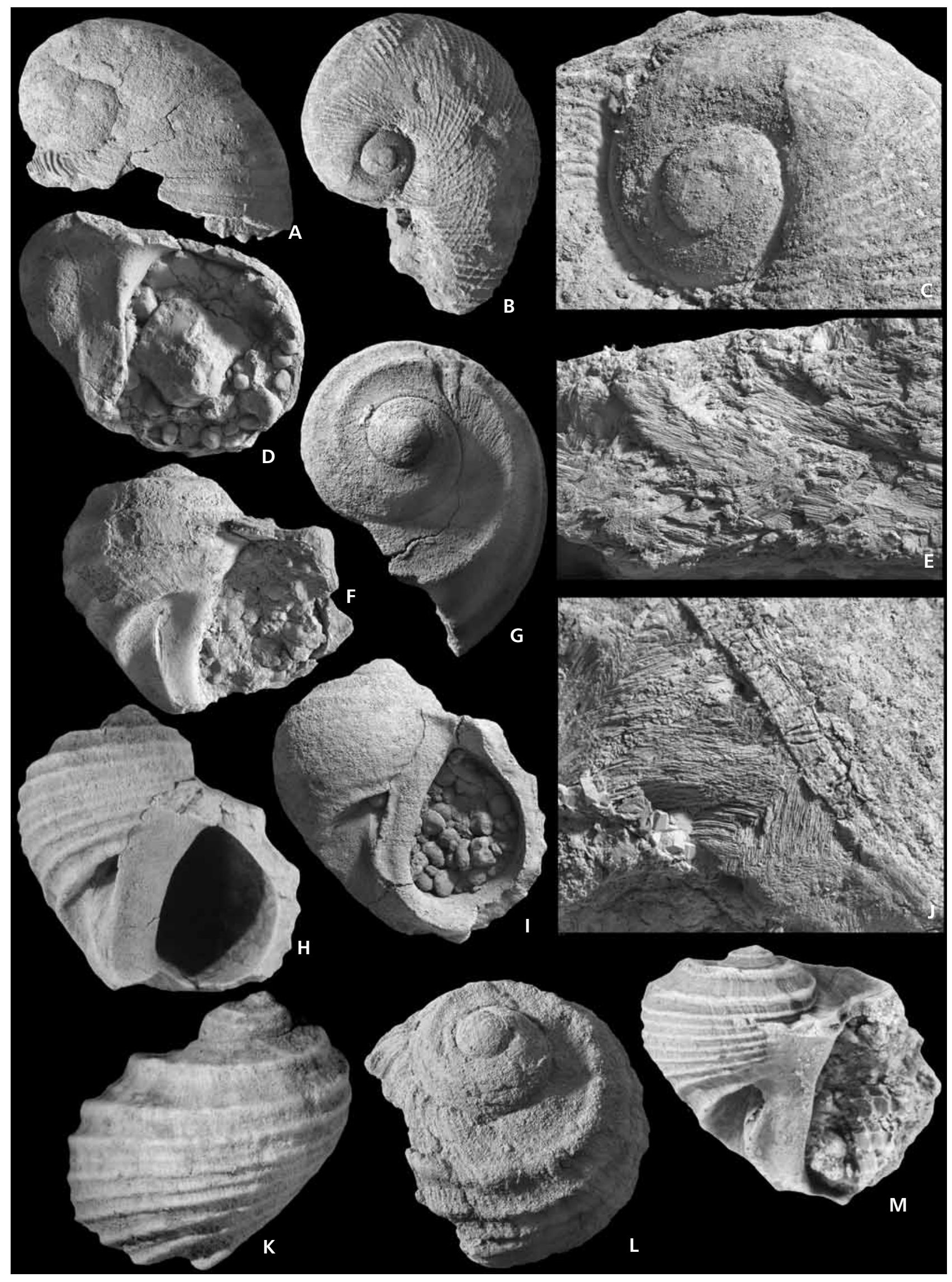


different species into his Naticella anomala, one that is clearly the same as that described by Laube (1869) and the other which may represent an individual of Cortinella Bandel, 1988 (Kittl (1892, pl. 7, fig. 28), with a small planispiral shell and strong axial ribs. It had been placed with Brochidium by Kittl (1892) and was later, when its shell became better known, interpreted as belonging to its own genus, Cortinella Bandel, 1988, and when its protoconch became known into an own family of the Neritimorpha (Bandel 2000), the Cortinellidae.

Not fully-grown shells of Marmolatella dieneri as described by Broili (1907, pl. 9, figs 16-18) would probably not differ from Marmolatella fenestrata, since the characteristic row of hollow spines preserved in the individuals from Seiser Alp occur only on shells which are larger than the largest Marmolatella fenestrata that is known from the St Cassian Formation.

Family Palaeonaricidae n. fam.

Type genus. - The family is based on the genus Palaeonarica Kittl, 1892 from the St Cassian Formation.

Diagnosis. -Shell shape is Nerita-like and consists of three whorls in the teleoconch. Ornament consists predominantly of spiral ribs. Aperture is semicircular with a straight inner lip connected to a smooth ribbon-like callus and a rounded outer lip. Protoconch is globular with convolute whorls and measures about $0.5 \mathrm{~mm}$ in diameter. The shell is thick walled with a thin outer calcitic layer and a thick inner aragonitic layer with crossed lamellar structure. The inner whorls of the shell are not dissolved.

Differences. - The Nerita-like shape distinguishes this new family from the Platychilinae which have similar features of their aperture. The straight and smooth inner lip of the aperture distinguishes it from the Neritopsidae which has a groove and tubercles. The ornament of the spiral ribs distinguishes it from the Scalaneritinidae in which the axial ribs are characteristic. They also have a convex inner lip of the aperture, in distinction to the straight inner lip of the Palaeonaricidae. The operculum is very solid and almost smooth with two scars on its inner side. It could be fitted into the aperture of Palaeonarica.

Remarks. - Yin \& Yochelson (1983) suggested that Fossariopsis differs from Palaeonarica in having only two keels, the upper of which forms the periphery and has a scale-like shape in its tubercles. The shell of Palaeonarica is lower and less stair-like, with a less prominent apical corner and more spiral ribs or keels, but also differs in the shape of the inner lip.

\section{Genus Palaeonarica Kittl, 1892}

Type species. - The genus is based on Palaeonarica pyrulaeformis, which has more spiral ribs than Palaeonarica concentrica. Both species of Palaeonarica are similar to each other in regard to size and shape.

Diagnosis. - Shell relatively large, as wide as high, of ovoid shape with a stair-like spire. Ornament consists of spiral ribs. Aperture oval, a little inclined and the inner lip has a narrow smooth callus and a simple, smooth and weakly concave inner edge.

Remarks. - Two species of Palaeonarica from the St Cassian Formation belong here. These species were originally described as Naticella pyrulaeformis Klipstein, 1843 and Naticella concentrica Münster, 1841 and clearly they are closely related to each other. Kittl (1892) discussed the relation of Palaeonarica to other gastropods and came to the conclusion that it more closely resembles Nerita and the Neritidae than Fossarus, as had been assumed by Laube (1869).

\section{Palaeonarica pyrulaeformis (Klipstein, 1843) Figure $6 \mathrm{H}-\mathrm{M}$}

Diagnosis. - The genus diagnosis also applies to the species. Whorls are ornamented by many spiral ribs. Umbilicus mostly open with a deep umbilical groove.

Remarks. - The species illustrated by Zardini (1978, pl. 18, figs 4,5 ) is quite characteristic with its spiral ornament and basal corner at the umbilical groove.

Description. - The teleoconch consists of about three whorls and is up to $23 \mathrm{~mm}$ in width and $20 \mathrm{~mm}$ high. It has a thick wall and a spherical to pear-shaped form with stair-like whorls which rapidly increase in diameter. The narrow flat of the concave apical flank ends in a keel, but it is only the next keel that forms the periphery. Between the first two keels there is a wide space, while several more keels follow in close distance to each other below on the sides. The last spiral rib is broader than the others and surrounds the umbilicus. Growth lines are strong and straight. The ornament is somewhat variable, but usually there are 10 to 14 spiral ribs. The aperture has an oblique semicircular shape with a rounded outer lip and an inner lip that extends in a smooth callus pad and has a weakly concave inner margin. It is wider in its upper part and is wall-like next to the umbilicus that usually remains open, but in some specimens is also completely covered. The shell has a solid thin outer calcitic layer that is underlain by a thick aragonitic layer with crossed lamellar structure. 
The protoconch is round and about $0.5 \mathrm{~mm}$ in diameter. It consists of an embryonic whorl and about 2 larval whorls with a smooth and straight aperture.

Differences. - Palaeonarica concentrica differs from $\mathrm{Pa}$ laeonarica pyrulaeformis in its often closed umbilicus, but more clearly by the fewer spiral ribs in its ornament. In the case where are 10 spiral keels, it is usually Palaeonarica pyrulaeformis. However, there appears to be an almost continuous overlap in shape and ornament of the two species.

Remarks. - The species was originally described as Naticella pyrulaeformis Klipstein, 1843, and subsequently transferred to the genus Fossarus by Laube (1869, pl. 30, fig. 4), which was not a good decision even though it was followed by Wenz (1938-1944); Wenz placed Palaeonarica in the Fossaridae, as had been proposed by Koken (1892). Kittl (1892, pl. 6, figs 15, 16) in contrast created the genus Palaeonarica, and interpreted the genus to be close to the Neritidae. This genus was used by Blaschke (1905, pl. 1, fig. 19) and Leonardi \& Fiscon (1959, pl. 4, figs 4, 5, 7). Zardini (1978, pl. 18, figs 1-5) illustrated both species well, but determined the Palaeonarica concentrica seen in pl. 17, figs 13-15 as Palaeonarica rugoso-carinata (Klipstein).

\section{Palaeonarica concentrica (Münster, 1841)}

Figure 6F, G

Diagnosis. - Shell ornamented with a few spiral ribs. Umbilicus often closed by the callus plate and umbilical furrow may be shallow; the latter two characters are variable among individuals.

Description. - The protoconch is about $0.5 \mathrm{~mm}$ wide and consists of several whorls, but its ornament is not preserved. The shell is thick-walled, globular and consists of 3 whorls which rapidly increase in diameter. The spire is low and stair-like with inclined apical flanks ending in the posterior-most spiral rib. The ornament consists of 6-8 strong spiral ribs crossed by more or less strong growth increments which may form low nodes with them producing the variety 'cancellata'. Spiral ribs cross the growth lines to form a pattern of rectangles. The second rib lies at the periphery and forms the greatest shell width and the rib next to the last surrounds the umbilicus. The last rib spirals into the umbilical depression and can fuse with the margin of the callus of the inner lip, forming the margin to the umbilical furrow. At 1.75 whorls of the teleoconch the shell is $2.9 \mathrm{~mm}$ high. Although the body whorls usually have 6 to 8 spiral ribs, there may be as many as ten. The specimen illustrated by Kittl (1892) from the NHMW collection is about $10 \mathrm{~mm}$ wide and $10 \mathrm{~mm}$ high and consist of about three whorls of the teleoconch. The oval and oblique aperture is higher than wide and a little inclined in relation to the coiling axis of the shell. The callus of the inner lip is smooth and extends over the umbilical region and is widest where it covers the actual umbilicus, while the groove towards the base of the shell is open and deep. The callus is somewhat variable in width and may be planar or grooved. In addition, the umbilicus may be open and the umbilical groove deep. Growth increments are more or less clearly visible within the groove. The species was illustrated by Zardini (1978, pl. 17, figs 13-15, pl. 18, figs 1-3).

Differences. - Palaeonarica pyrulaeformis has a wider apical shell and the uppermost spiral rib is closer to the suture than is the case in Palaeonarica concentrica. The inner lip of Palaeonarica concentrica may have its callus extended into the umbilical depression, while in the case of Palaeonarica pyrulaeformis the callus more often lies parallel to the umbilical furrow and does not cover it. Fossariopsis rugosocarinata differs from Palaeonarica in having a tubercle-bearing upper keel and hollow spines, but the most obvious difference lies in the teeth on the inner side of the inner lip.

Remarks. - The species was originally named Naticella concentrica Münster, 1841 (Münster 1841, pl. 10, fig. 23). It was placed in Fossarus by Laube (1869, pl. 30, fig. 3), and with Palaeonarica by Kittl (1892), who determined it a variety that he named Palaeonarica constricta (Kittl 1892, pl. 6, figs 13, 14). The holotype of Palaeonarica constricta Kittl, 1892 from the collection at NHMW is a well preserved specimen with the spirals in part tubercle bearing. The tubercles are the result of strong increments of growth crossing the spiral ribs. Broili (1907, pl. 7, fig. 42) described Palaeonarica concentrica, as did Leonardi \& Fiscon (1959, pl. 3, fig. 1), who also recognized the variety Palaeonarica concentrica var. constricta. Zardini (1978) illustrated it using the names Palaeonarica concentrica and Palaeonarica rugoso-carinata.

Both species of Palaeonarica commonly occur in the locality Costalaresc, and they are present in Alpe di Specie as well as in Misurina and have also been found in Rumerlo (see Zardini 1978 and Wendt 1982 for a map).

Family Naticopsidae Waagen, 1880

Type genus. - The family is based on Naticopsis as illustrated by Knight (1941, pl. 83, fig. 3a, b) from the Early Carboniferous of Ireland.

Diagnosis. - Rounded shell ornamented by subsutural collabral growth lines or smooth with a rounded outer lip; in- 
ner lip thickened. Whorls rounded and separated from each other by deep sutures. Shells may be relatively large. Protoconch consists of more than two whorls, is about or larger than $0.5 \mathrm{~mm}$. Where known, ornament consists of sinuous collabral ribs on its larval whorls which reflect the presence of a deep median sinus in the outer lip.

Remarks. - The thickening of the inner lip is typical of the genus that is central to the family (Knight 1941, pl. 83, fig. $3 a, b)$, as well as the ornament of the larval shell (Bandel 2002, figs 143-147).

\section{Genus Naticopsis M'Coy, 1844}

Type species. - The type of the genus is Naticopsis phillipsii M'Coy, 1844 from the Lower Carboniferous of Ireland (Knight 1941; Wenz 1938-1944, fig. 976).

Diagnosis. - Shell large (up to $60 \mathrm{~mm}$ high and wide), with more than three whorls bearing fine collabral ornament. Whorls smoothly rounded; adult shell consists primarily of the body whorl. Sutures deep. Base simple without umbilicus. Inner lip concave covering the former shell wall in a thick callus layer. Protoconch and shell structure of type species unknown.

Remarks. - In the case of Naticopsis ventrica (Norwood \& Pratten, 1855) from the Late Carboniferous of Texas the protoconch is known. According to Kues \& Batten (2001, figs 12,1-9), the shell of this species reaches a relatively large size (almost $30 \mathrm{~mm}$ ) but they did not study the protoconch. The early whorls of the teleoconch are ornamented by collabral small sharp ribs, which are not developed on later whorls. Its shape closely matches that of the genotype of Naticopsis. A protoconch that was considered to belong to that species (Bandel 2002, figs 143-147) was found to consist of a smooth embryonic whorl of $0.15 \mathrm{~mm}$ in diameter, succeeded by 1.5 whorls of the larval shell with an ornament of sinuous axial lines. The lines reflect the shape of the outer lip that has a deep median sinus and a narrow basal lobe. The teleoconch has straight growth lines. The larval shell measures about $0.6 \mathrm{~mm}$ in width and height. Similar protoconch ornament was found by Herholz (1992) among microgastropods from the Late Carboniferous of Germany.

Among the Neritimorpha of the St Cassian Formation, two new subfamilies, the Ampezzonaticopsinae and the Hologyrinae, are here included with the Naticopsidae.

Subfamily Ampezzonaticopsinae n. subfam.

Type genus. - The subfamily is based on Ampezzonaticopsis $\mathrm{n}$. gen.
Diagnosis. - Low conical small shell with pointed spire and evenly coiled whorls having deep sutures. Larval whorls of the protoconch conspicuously ornamented by sinuous collabral axial ribs which reflect a lobed outer lip. Aperture of the teleoconch rounded with a concave callus of the inner lip accompanied by an umbilical groove around the open umbilicus. Shell has a continuous calcitic outer layer and a thicker, internal aragonitic layer of crossed lamellar structure.

Genera included. - Ampezzonaticopsis n. gen. and Cortinaticopsis $\mathrm{n}$. gen.

Differences. - The larval shell of Hologyra has sinuous ribs on the upper and lower side of its whorls ending in a median ribbon, which is not present in Cortinaticopsis n. gen. However, in the case of Ampezzonaticopsis n. gen., the median zone has an ornament of rows of tubercles connected to some median spiral lines. The larval shell of Cortinaticopsis $\mathrm{n}$. gen. comes closest in shape and ornament to that of the Pennsylvanian Naticopsis, as illustrated by Bandel (2002). The teleoconch of the Ampezzonaticopsinae has a relatively thin shell compared with that of the Hologyrinae. In addition, another difference is the shape of the umbilical groove in the two species of the Ampezzonaticopsinae described here, which is not partly filled with a ridge as in the case of Hologyra.

\section{Genus Ampezzonaticopsis n. gen.}

Type species. - The genus is based on Natica sublineata Münster, 1841 from the St Cassian Formation.

Diagnosis. - Small shell consisting of rounded whorls set off from each other by deep sutures in the teleoconch that has more than three whorls. The last whorl makes up at least two thirds of spire height. Outer calcitic shell layer has a lamellar pattern and easily peels off exposing the smooth surface of the inner aragonitic crossed lamellar layer. Aperture rounded with the callus of the inner lip bearing a groove and an inner margin that is concave. Base of the shell opens to a narrow, rounded umbilicus. Ornament of the larval shell consists of sinuous and collabral rows of tubercles with a median whorl having spirals composed of fine tubercles.

Name. - The species that serves as the type to the new genus resembles the Paleozoic genus Naticopsis and comes from region of Ampezzo in the Italian Dolomites. Hence, the name Ampezzonaticopsis, which is a combination of both.

Remarks. - The type was determined as Naticella sublineata by Kittl (1892, pl. 7, figs 41, 42) and is well illustrated 
by Zardini (1978, pl. 20, figs 2-4). Here the characteristic rounded whorls, deep sutures, simple aperture and conical shape with characteristic dense lamellar pattern of growth increments are well documented.

The name Naticella used by Kittl (1892) is preoccupied (Naticella Grateloup, 1840 for a naticid). Naticella Perner, 1907, which had been changed into Naticellina Perner, 1911, is based on the genotype Naticella suavis Perner, 1907. It lived in the Silurian of Bohemia and has been illustrated by Knight (1941, pl. 83, fig. 6). It represents a Natica-like shell with smooth surface with the last whorl enclosing most of the other whorls. The protoconch is unknown and the inner lip has a straight inner edge. It is not useful to use genus name for Late Triassic species because of the long time span of more than 200 million years that elapsed since the Silurian, as well as the incomplete knowledge of Naticellina regarding protoconch ornament and shell composition.

\section{Ampezzonaticopsis sublineata (Münster, 1841) Figure 7B-G}

Diagnosis. - Low conical shell with a pointed spire and evenly coiled whorls having deep sutures. Shell consisting of an outer calcitic layer with straight lamellar growth increments and a thicker aragonitic inner layer in crossed lamellar structure. Protoconch with three rounded whorls has its larval shell ornamented by collabral axial ribs connected to a central zone with granular spirals. Ornament reflects the strongly lobed outer lip of the larval shell. Aperture of the teleoconch is rounded; its inner lip concave and has a callus with a depression that is accompanied on its outer side by an umbilical groove. Umbilicus of the teleoconch open.

Remarks. - The description of the genus applies to the species.

Description. - The shell has rounded whorls which increase slowly in diameter and have deep sutures. The protoconch is of globular shape and is more than $0.5 \mathrm{~mm}$ high and wide with three whorls. The larval shell is ornamented by crescentic collabral axial ribs and spiral ribs close to each other in the middle of the whorl. The axial as well as the spiral ribs may be continuous or composed of granules. A sinus is present on the apical part of the outer lip of the larval shell, reflected in the outline of the ribs. The spiral ribs in the middle of the larval whorls become covered by the first whorl of the teleoconch.

The teleoconch is as wide as high and consists of up to 4 whorls which are evenly rounded. Its umbilical area is narrow and open, and the aperture is simple and rounded. The composition of the shell is such that the thin outer calcitic layer easily peels off from the smooth aragonitic layer below it. Individuals in which that has occurred can appear to belong to a different species. This calcitic layer with solid and characteristic, poorly ordered structure has a characteristic ornament of simple collabral lamellae in dense arrangement, but is slightly variable, as can also be noted in the illustration of the species presented by Zardini (1978, pl. 20, figs 2-4). This distinction may have its origin in the differing degrees of corrosion of the outer calcitic layer of the shell.

Differences. - Shell size and number of whorls is less than in Cortinaticopsis n. gen. and growth increments appear more lamellar. In addition, the umbilicus remains open in Ampezzonaticopsis n. gen., while it is covered with the callus of the inner lip in Cortinaticopsis n. gen. In the case of Hologyra the last whorl covers most of the former whorls, the shell wall is thicker and the umbilical thickening as well as the solid callus of the inner lip differs, while the ornamental pattern of the larval shell is similar to that of Ampezzonaticopsis $\mathrm{n}$. gen. The protoconch has a pattern of sinuous lines partly composed of tubercles as ornament of the larval whorls as in Ampezzonaticopsis n. gen. and is more similar to Cortinaticopsis n. gen., which has more continuous sinuous lines than Hologyra with its two median lines with crescentic ribs in between.

Remarks. - The species was documented as Naticella sublineata by Kittl (1892, pl. 7, figs 41, 42), and by Zardini (1978, pl. 20, figs 2-4) with its narrow axial lamellae well displayed. Kittl (1892) suggested placing most of the species from the St Cassian Formation that had been placed into Naticella by Münster (1841) with Naticopsis, leaving four species in the original genus of which all represent rather unrelated species as is evident now when larval shells and the inner lip of the teleoconch are compared: Naticella striatocostata is a member of the Tricolnaticopsidae; Naticella anomala of Kittl's (1892) characterization represents two different species, one of which belongs to Marmolatella of the Pachychilininae; and also Naticella acutecostata, which probably actually represents two different species, one of which is placed here in the genus Ladinaticella n. gen., and the other in Colubrellopsis n. gen. Only Naticella sublineata of that group remains as a form related to Naticopsis.

\section{Genus Cortinaticopsis n. gen.}

Type species. - The genus is based on Natica impressa Münster, 1841 from the St Cassian Formation.

Diagnosis. - Large shell with thin shell wall and up to five whorls. Teleoconch large with umbilicus closed. Larval 
shell has an ornament of sinuous axial ribs with a characteristic strong median lobe and sinus. Continuous and thin outer calcitic layer and inner aragonitic layer with crossed lamellar structure.

Differences. - The teleoconch closely resembles that of Ampezzonaticopsis but attains larger size and has a closed umbilicus.

Name. - The genus name is a combination of Cortina (after the Cortina d'Ampezzo) and Naticopsis.

\section{Cortinaticopsis impressa (Münster, 1841)}

Figure 7A, H-L

Diagnosis. - Shell with regular narrow growth increments strongly imprinted in the outer calcitic layer and having an aperture with a rounded inner lip covered by a narrow callus ribbon with a groove in its middle. Callus covers the concave umbilical area. Protoconch consists of three whorls and teleoconch of up to five whorls and larval whorls ornamented by crescentic axial ribs with a narrow, strong median sinus.

Description. - The shell may be $8 \mathrm{~mm}$ wide and $7 \mathrm{~mm}$ high with about three whorls in the teleoconch, in the case of the specimen determined by Kittl (1892) and studied from the NHMW collection. The shells of large individuals have usually been crushed by compaction, and they may reach a size of up to $20 \mathrm{~mm}$ in size. Whorls are rounded and have collabral growth increments with a short distance from each other, sometimes somewhat irregular. The aperture is semicircular with a straight inner lip and rounded outer lip. Callus of the inner lip consists of a ribbon that in its apical portion is a little wider than it is further towards the base and bears a shallow rounded groove in its middle. Next to the callus lies a wide umbilical furrow that starts in the narrow umbilicus, which is covered by the apical portion of the callus. The thin callus of the inner lip covers the concave umbilical area and fully-grown shells consist of up to 5 whorls in the teleoconch.

The ornament of the protoconch is characterized by collabral ribs on the larval shell that reflect the shape of the lobe and sinus on the outer lip. The protoconch consists of about three rounded whorls and is about $0.6 \mathrm{~mm}$ high and wide. The succeeding teleoconch has straight increments of growth. The species occurs commonly at locality Campo, where the shells are often more or less deformed.

Remarks. - The shell illustrated by Kittl (1892, pl. 7, figs 16,17$)$ resembles that illustrated by Zardini (1978, pl. 19, fig. 21). Natica berwerthi Kittl, 1892 is also described as thin and with a closed umbilicus. The large shell of a species determined as Solarioconulus nudus (Münster, 1841) and illustrated by Zardini (1978, pl. 11, fig. 11) has rounded whorls bearing the original color pattern of zigzag lines, deep sutures, a wide base and an umbilicus closed by the callus of the inner lip. Specimens from Misurina and Alpe di Specie also probably also belong to this species having relatively large and thin-walled shells that are usually deformed and crushed.

Subfamily Hologyrinae n. subfam.

Type genus. - The subfamily is based on the genus Hologyra Koken, 1892 as redefined from the St Cassian Formation.

Diagnosis. - Shell has rounded whorls with a low spire and large final whorl. Inner walls preserved and outer walls are thick. Protoconch has a larval shell with an ornament of collabral ribs on the lower and upper side, interrupted in the middle of the whorl by two distinct spiral lines, which have curving ribs between them forming a chevron. Callus of the inner lip of the teleoconch lies next to a column-like ridge composed of growth increments; this articulated ridge extends from the umbilical furrow to the base, ending before reaching the margin of the outer lip. Operculum calcareous and with angular inner side bearing two rounded attachment scars and a rounded outer side; the latter has an inner triangular portion with straight increments of growth and a semicircular outer part with rounded concentric growth lines, the nucleus lying in the point of the triangular part.

Figure 7. A - slightly deformed specimen of Cortinaticopsis impressa (Münster, 1841). Shell about 11 mm wide (BSPG 2007 XVI 44). - B - protoconch of Ampezzonaticopsis sublineata (Münster, 1841) with shell shown about 0.7 mm high. • C - larval shell of Ampezzonaticopsis sublineata (Münster, 1841) with ornament and about $0.5 \mathrm{~mm}$ high (BSPG 2007 XVI 41). • D - protoconch of Ampezzonaticopsis sublineata (Münster, 1841 ) in early teleoconch, about $0.8 \mathrm{~mm}$ high (BSPG 2007 XVI 42). E - apical view of the protoconch of Ampezzonaticopsis sublineata (Münster, 1841) of the same specimen as in Fig. 7D. • F - apical view of juvenile shell of Ampezzonaticopsis sublineata (Münster, 1841). Shell about 0.7 mm wide (BSPG 2007 XVI 43). • G - Ampezzonaticopsis sublineata (Münster, 1841). The same shell (about $0.7 \mathrm{~mm}$ high) as in Fig. 7F, but in apical view. • H - juvenile shell of Cortinaticopsis impressa (Münster, 1841). Shell almost $3 \mathrm{~mm}$ high (BSPG 2007 XVI 45). • I - the same shell of Cortinaticopsis impressa (Münster, 1841) as in Fig. 7H seen from above. Shell is $2.8 \mathrm{~mm}$ wide. $\bullet \mathrm{J}$ - Cortinaticopsis impressa (Münster, 1841). Shell about $1.5 \mathrm{~mm}$ wide (BSPG 2007 XVI 46). $• \mathrm{~K}$ - protoconch of Cortinaticopsis impressa (Münster, 1841) with the initial portion of the teleoconch about $1.2 \mathrm{~mm}$ high (BSPG 2007 XVI 47). $\bullet \mathrm{L}$ - larval shell of Cortinaticopsis impressa (Münster, 1841) in a juvenile specimen. Shell about 0.8 mm high (BSPG 2007 XVI 48 ). 


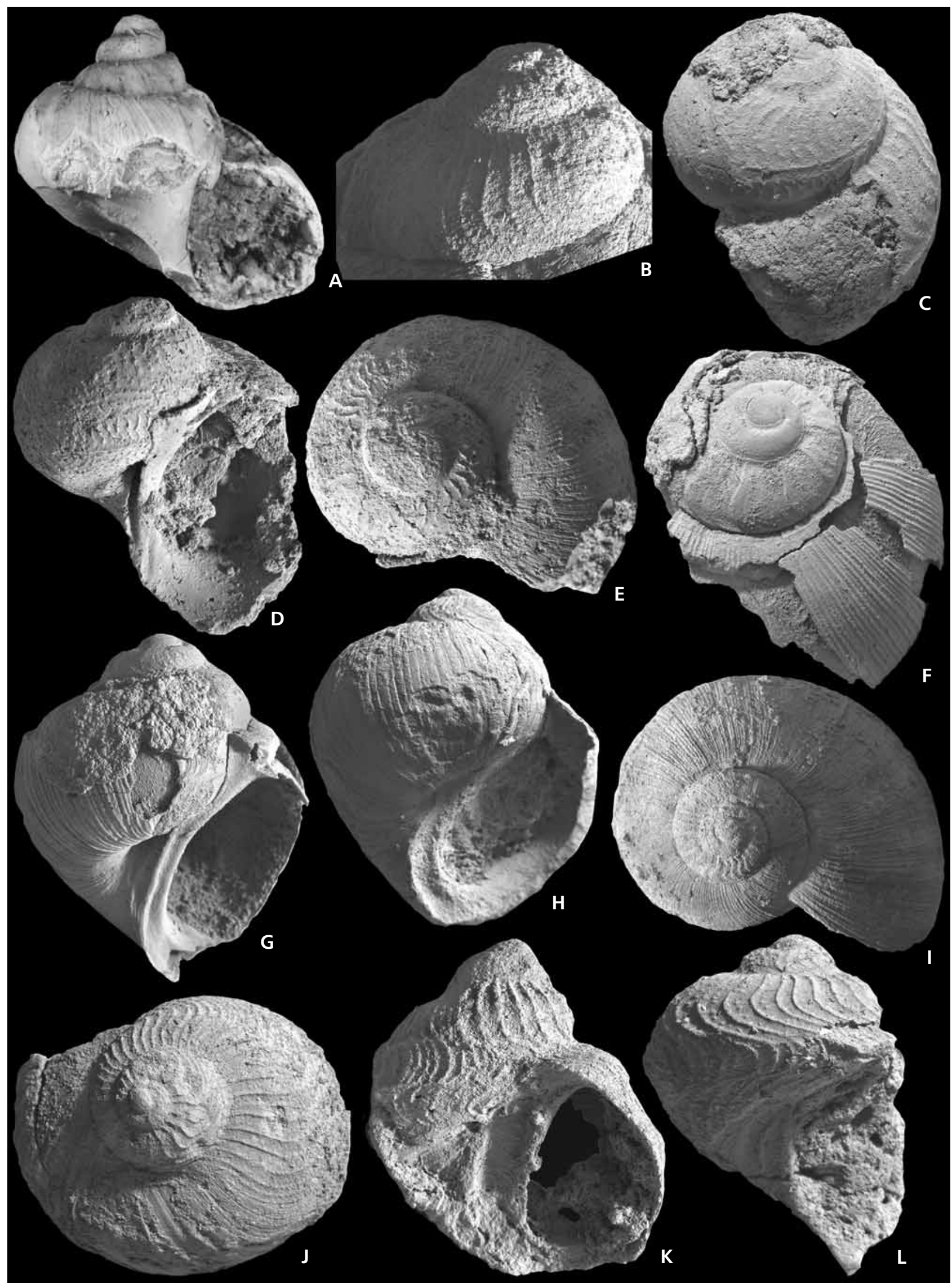


Differences. - The protoconch has a characteristic ornament on the larval shell and a ridge in the umbilical groove of the teleoconch, which distinguishes the Hologyrinae from all other Neritimorpha of the St Cassian Formation with globular shells. The larval shell of the Ampezzonaticopsinae also has sinuous axial ribs, but the shape of the teleoconch differs in its relatively higher spire, a less thick shell wall, concave umbilical furrow, and deeper sutures. The chevron in the middle of the larval whorls is found only in Hologyra. The Fedaiellidae with similar, solid rounded shells have a lowly rounded protoconch that resembles that of the Cassianopsinae, in addition to the angular groove on their inner lip of the teleoconch. The Neritariidae with Neritaria mandelslohi also has individuals with a relatively large rounded shell, but the lowly rounded protoconch also has low axial ribs. The shell has its inner whorls dissolved.

Remarks. - Zardini (1978, pl. 21, figs 5-7) illustrated the two characteristic muscle attachment scars. The operculum preserved in Hologyra cassiana has the same general features as that known as Hypodema Koninck, 1853, which is connected to a Naticopsis from the Carboniferous (Gordon \& Yochelson 1982). It consists of a shield-shaped triangle at the base and on top of it a rounded part with concentric growth lines with their center present in the point of the triangle (Knight 1941, pl. 83, fig. 5); Knight suggested that the operculum belongs to Naticopsis, which occurs in the same Lower Carboniferous beds at Visé in Belgium. In addition, Kittl (1892) compared the operculum of the Carboniferous Naticopsis that was described by Koninck (1853) from Lower Carboniferous deposits with that of Hologyra cassiana from the St Cassian Formation.

\section{Genus Hologyra Koken, 1892}

Type species. - The genus is based on Natica cassiana Wissmann, 1841 from the St Cassian Formation. The choice of a different type as originally suggested by Koken (1892) is discussed below.
Diagnosis. - Globular shell with a short spire and straight increments of growth. Umbilical furrow in juvenile shells is bordered by an inner lip with a sharp outer keel and in it a ridge composed of growth increments; ridge in mature shells can be covered by the thick callus of the inner lip. During shell growth teleoconch morphology changes from highly rounded juvenile shell to broadly rounded adult shell. Protoconch characteristized by two median spiral lines and axial ribs between forming a ribbon of crescentic lines with the same spacing as is found in the sinuous axial ribs on whorls above and below. Vertical aperture of the teleoconch can be sealed with a calcareous operculum that has a triangular base next to the inner lip and an outer side bearing concentric growth lines.

Differences. - Kittl (1892) characterized this genus and noted that the pillar in the umbilical furrow may be more or less callus covered. Thus, Naticopsis cassiana merges with Naticopsis expansa Laube, 1869, which represent different growth stages of Hologyra and also reflect different degrees of corrosion of the shell. The pillar in the umbilical furrow distinguishes it from Fedaiella, and the latter genus in addition has a groove bordered by teeth on the inside of its inner lip. Among the Neritimorpha from the St Cassian Formation, only Hologyra has an umbilical ridge with growth increments.

\section{Hologyra cassiana (Wissmann, 1841) Figure 8A-M}

Diagnosis. - Rounded shell quite large with inner whorls not dissolved (checked by cutting shells). Solid callus plate of the inner lip connects to or may cover the rounded plug-like ridge that fills the inner side of the umbilical furrow; the column is small in juvenile shells, well developed with growth increments in larger shells and may be covered by the callus plate in fully-grown shells of older individuals. Operculum has a triangular basal part and outer portion with rounded growth lines.

Figure 8. All figures (A-M) illustrate Hologyra cassiana (Wissmann, 1841). A - operculum is present with its nucleus in the outer half. The shell is about $2 \mathrm{~mm}$ wide (BSPG 2007 XVI 49). B - operculum of an older individual with a shell about $5 \mathrm{~mm}$ wide (BSPG 2007 XVI 50 ). $\bullet$ C - the large triangular basal part of the operculum is almost smooth, while the outer part is rounded and concentric (BSPG 2007 XVI 51). • D - the callus of the inner lip is accompanied by a ridge in the umbilical groove next to it. Shell about $6 \mathrm{~mm}$ wide (BSPG 2007 XVI 52). $\bullet$ E - juvenile shell with the first whorl of the teleoconch still with indistinct umbilical ridge and the visible larval ornament. Shell $1.8 \mathrm{~mm}$ high (BSPG 2007 XVI 53). • F - older shell with callus of the inner lip thickened and covering most of the umbilical groove and its ridge. Shell about 9 mm in diameter (BSPG 2007 XVI 54). • G - the umbilical ridge (funiculus) and the groove next to it with strong growth increments. Shell about $5 \mathrm{~mm}$ high (BSPG 2007 XVI 55). $\bullet \mathrm{H}-$ the larval shell with its characteristic ornament of collabral ribs and two median lines with pattern of lunate ribs between them. The juvenile teleoconch is about $1.8 \mathrm{~mm}$ high (BSPG 2007 XVI 56). $\bullet$ I - detailed view of the larval ornament, as in Fig. 8H. $\bullet \mathbf{J}-$ protoconch connected to the teleoconch with the characteristic pattern of the genus. The shell is $1.8 \mathrm{~mm}$ wide. $\bullet \mathrm{K}$ - a shell with $3 \mathrm{~mm}$ in height and with the calcitic layer with lamellae and the bulk crossed lamellar in the thick wall (BSPG 2007 XVI 57). $\bullet$ L - juvenile shell as in Fig. 8K seen from the apex. $\bullet \mathrm{M}-$ the protoconch of about $0.5 \mathrm{~mm}$ in its teleoconch, detailed view of Fig. 8L. 


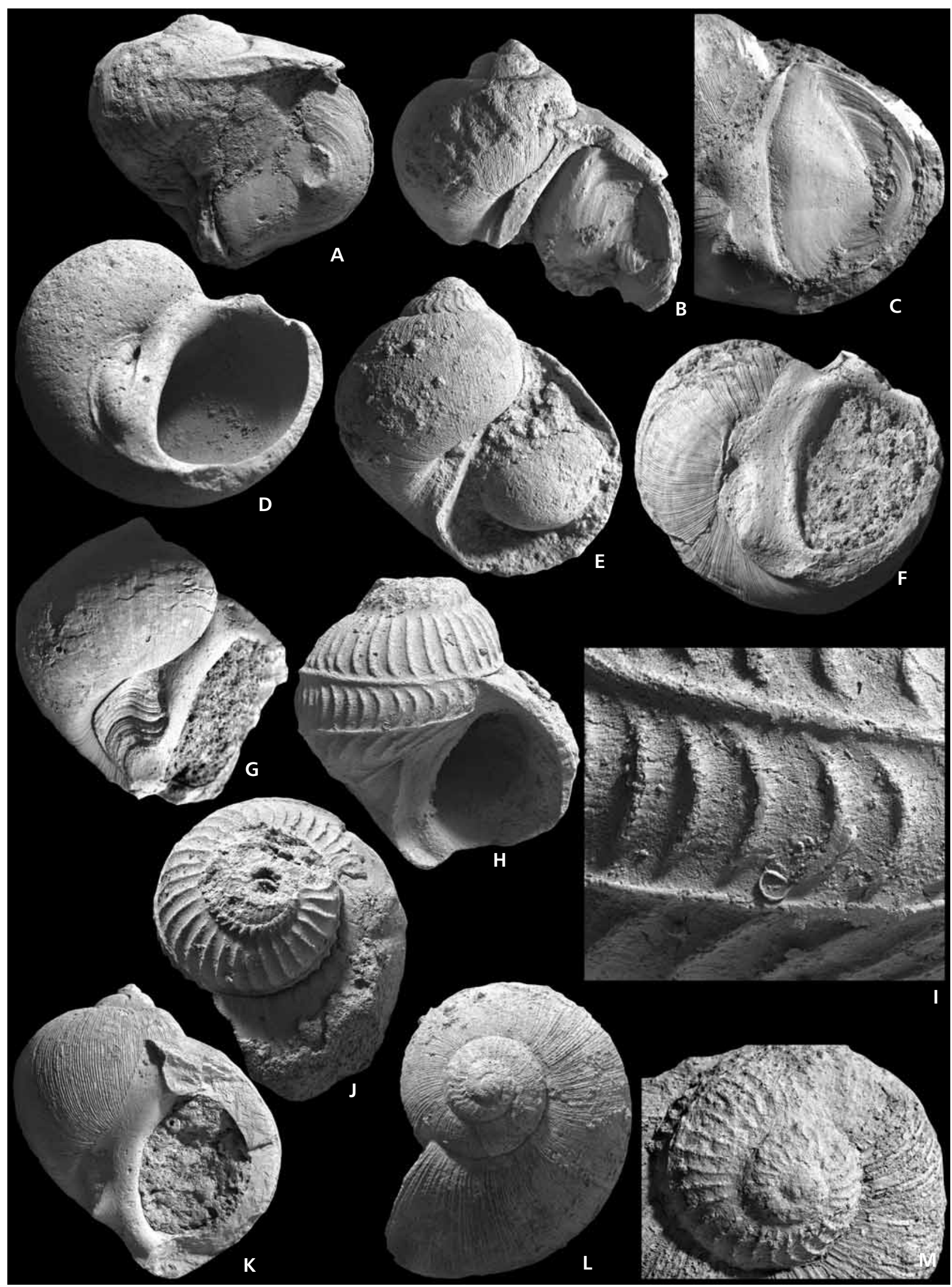


Description. - The solid teleoconch is of globular shape, about as wide as high and consists of about four whorls. It may be up to $25 \mathrm{~mm}$ in width and height. A shell with 2.75 whorls of the teleoconch is about $4 \mathrm{~mm}$ wide and less than $4 \mathrm{~mm}$ high, with a spire less than $0.5 \mathrm{~mm}$ high. The body whorl covers most of the former whorls. Ornament consists of thread-like growth increments which are straight in early whorls, and later develops a slight curvature. The evenly rounded outer lip ends with an anterior notch. It forms a groove between the outer lip and the anterior part of the inner lip. The aperture has a semicircular shape and oblique orientation to the axis of coiling of the shell. The inner lip forms a flat callus that ends next to the umbilical groove which has the ridge of the so-called "funiculus" (columellar ridge - see below) in it (Kittl, 1892). This ridge has a characteristic pattern of step-like increments of growth. Due to the change in callus dimension during growth of the shell this umbilical ridge may be more or less covered by it. This results in the description of a number of supposed species centered around this species which differ by callus shape and are just varieties. Ornamental patterns of dark spiral zigzag ribbons may be preserved on the shell (Kittl 1892, pl. 7, fig. 16; Tichy 1980, pl. 3, fig. 9).

The protoconch is about $0.5 \mathrm{~mm}$ wide and high and in part covered by the first whorl of the teleoconch, exposing the ornament of its larval shell only up to the apical spiral line in the middle of the whorl. The embryonic whorl is about $0.1 \mathrm{~mm}$ wide and is succeeded by about 1.75 larval whorls with an ornament of about 40 collabral ribs on one whorl. Axial ribs have a curving shape reflecting the aperture and on the last half whorl have a spiral rib just above the suture and a second spiral rib which is covered by the succeeding whorl. Short axial ribs form a chevron-like ribbon between the spiral ribs.

The operculum is constructed of calcitic material and has a darker color than the shell. Its semicircular shape matches that of the aperture. Its inner side reflects the concave curvature of the inner lip. With the exception of the granular, inner marginal rounded area, the outer side of the operculum has a fine pattern of growth increments. The nucleus lies eccentrically near the middle but towards the outer lip. From its growth increments can be followed the outline of the outer lip, but it ends in a triangular inner zone or continues here as weakly developed straight growth increments. The inner side of the operculum is well illustrated by Zardini (1978, pl. 21, figs 5-7). Here a median ridge is accompanied on both sides by grooves with a concentric pattern. Its outer margin is smooth and thickened.

Differences. - Hologyra cassiana is distinguished from the other species of the "Naticopsis" group by the presence of an articulated column in the umbilical groove. This character also distinguishes it from Neritaria mandelslohi, which also has a strong tooth on the inner side of the inner lip near the base of its aperture. Both species attain large size, but have very different shaped opercula. In addtion, Neritaria mandelslohi dissolves its inner shell walls. The operculum of Hologyra cassiana is distinguished from that of the other species by having a more marginal position of the nucleus and concentric furrows on its outer side.

Remarks. - Natica cassiana of Wissmann (1841 in Münster 1841, pl. 10, fig. 3) was also documented by Laube (1869) who, in addition, described probably the same species also as Natica expansa Laube, 1869 and Natica althusii Klipstein, 1843. Kittl (1892, pl. 7, figs 18-21, pl. 9, figs 9, 10) called it Naticopsis cassiana, but also determined a Naticopsis expansa. He suggested a relationship with Naticopsis impressa (Münster, 1841), and Naticopsis involuta Kittl, 1892, which have no pillar in the columellar furrow. He distinguished a whole group of species to comprise the Naticopsis cassiana- like species of the St Cassian fauna. Kittl (1892) recognized the relationship with Naticopsis due to an operculum that had been described by Koken (1889) from Naticopsis deshayesi Klipstein, 1843. This latter species also belongs here since it has the columellar ridge (funiculus). In Koken (1892) a similar shell was called Hologyra alpina Koken, 1892 and Hologyra carinata Koken, 1892. Böhm (1895) used Hologyra alpina, and created Hologyra kokeni Böhm, 1895. The species from Seiser Alp was determined as Neritaria cassiana by Blaschke (1905, pl. 20, fig. 11) and also by Broili (1907, pl. 9, figs 8, 12, 15). Leonardi \& Fiscon (1959, pl. 3, fig. 3) called it Hologyra expansa, as did Zardini (1978, pl. 19, figs 6, 10-12, 23, 24; 1985, pl. 8, fig. 3). Zardini (1978, pl. 21, figs 5, 6, 10) also described its operculum. Similar individuals from the Muschelkalk were called Hologyra noetlinigi Picard, 1903 and Hologyra beyerichi Picard, 1903 and of these Hologyra noetlingi was confirmed by Gründel (1980, pl. 1, figs 9, 10). Knight et al. (1960, fig. 181, 4a, b) suggested Hologyra to be a synonym of Dicosmos Canavari, 1890.

Family Tricolnaticopsidae n. fam.

Type genus. - Tricolnaticopsis $\mathrm{n}$. gen. The family is based on Tricolnaticopsis striatulus (Münster, 1841) from the St Cassian Formation.

Diagnosis. - Smooth shell is higher than wide. Callus of the inner lip extends into the umbilical area and is convex on its margin to the aperture; basal part of the callus accompanied by a narrow furrow with a sharp outer margin. Thin outer calcitic layer underlain by a thick uniform aragonitic layer in crossed lamellar structure. Aperture shaped to accommodate a bean-shaped operculum, calcitic with two muscle attachment scars on its inner side and no inner pro- 
jection, with a rounded thickened margin; nucleus lies at the inner basal margin and is visible on the outer side. Operculum grows by concentric increments of uneven thickness.

Remarks. - The type species Tricolnaticopsis striatulus (Münster, 1841) was documented as Natica pseudospirata by Zardini (1978) from the St Cassian Formation. Two species of Pachyomphalus are considered to belong here, due to the shape of their aperture into which a similar bean-shaped operculum can be fitted. Some species which resemble the modern vetigastropod Tricolia in having a smooth shell and preserved inner whorls are here included, such as the slender Natica pseudospirata with rounded whorls, here described as Tricolnaticopsis striatulus. $\mathrm{Pa}$ chyomphalus uhligi with less rounded whorls as described by Kittl (1892) and the shorter Pachyomphalus angustus as described by Laube (1869) are also similarly characterized. The apertural rim of Rinaldopsis ampezziensis resembles that in Pachyomphalus and may indicate a relationship to the Tricolnaticopsidae.

Differences. - The genus Vernelia Böhm, 1895 is based on Vernelia excelsa (Hauer) and has similar shell shape, but is of much larger size (Wenz 1938-1944, fig. 892). Rinaldopsis as illustrated in Zardini (1978, pl. 30, figs 13, 14, pl. 31, figs 3-5) has a tricoliform shell shape, but has an inner lip that forms a wide callus. It differs also by its more irregular growth, while the shape of the aperture shows similarities with that of the Tricolnaticopsidae.

\section{Genus Tricolnaticopsis n. gen.}

Type species. - The type is Tricolnaticopsis striatulus from the St Cassian Formation, locality Seelandalpe (Alpe di Specie), as illustrated by Zardini (1978, pl. 20, figs 17, 19, pl. 21, figs 2-4).

Diagnosis. - Shell higher than wide. Rounded whorls compose the shell with the final whorl higher than the spire. Protoconch consists of three rounded whorls with a straight margin in the larval shell. Shell composition with a thin calcitic outer layer and a thick inner aragonitic layer. Color pattern consisting of rounded dots arranged in rows or zigzag lines can be preserved. Inner lip of the oval aperture is convex and forms a callus pad that covers the umbilical area.

Genus name. - The name is derived from the Tricolia-like shape of this member of the Neritimorpha which shows characters of Naticopsis group as documented by Kittl (1892). As such, the name represents a combination of both taxonomic names.
Tricolnaticopsis striatulus (Münster, 1841)

Figures 9A, B, N, 10A

Diagnosis. - Smooth shell resembles that of a Tricolia and has a continuous thin calcitic surface that bears colored dots. Aperture is rounded and the last whorl is higher than the spire. Callus of the inner lip has a convex bulge into the space of the aperture and forms a callus pad that covers the umbilicus. Rounded whorls of the teleoconch with deep sutures. Protoconch conical and its whorls rounded.

Description. - The shell consists of 4 whorls in the teleoconch and is about 7 to $8 \mathrm{~mm}$ high and about $6 \mathrm{~mm}$ wide with an apical angle of about $50-60^{\circ}$. Whorls are rounded, smooth, and separated by deep sutures. The outermost layer of the shell is a very thin but continuous layer of calcite, which commonly preserves the original color pattern of dots that are commonly arranged in zigzag lines oriented axially. This pattern varies strongly among the few individuals that were studied. The inner aragonitic layer is thick and consists predominantly of crossed lamellar structure. The orientation of the main lamellae is parallel to the outer lip. The callus of the inner lip is simple and smooth. It covers the umbilicus and forms a rounded pad and expands to the inner margin of the aperture and forms a rounded lobe. The inner walls of the shell are not dissolved.

The protoconch consists of more than two rounded whorls and is about $0.5 \mathrm{~mm}$ wide and high. The ornament of its larval whorls is not preserved.

Differences. - This species was well illustrated and described by Zardini (1978, pl. 20, figs 17, 18, pl. 21, figs 2-4) and was determined by him as Natica pseudospirata. Some of the individuals described as Natica argus Kittl, 1892 by Kittl (1892, pl. 7, figs 44-46) might belong here. The shape and size of Tricolnaticopsis striatulus resembles that of Pachyomphalus uhligi, but differs in having a relatively higher spire, deeper sutures, a more regular callus of the inner lip, an ornament of dots and smoother and more evenly curved outer shell surface.

Remarks. - Natica argus Kittl, 1892 as illustrated by Kittl (1892, pl. 7, figs 44-46) appears to represent the species that was illustrated by Zardini (1978) and determined as Natica pseudospirata. Kittl (1892) described his Natica argus as connected to a protoconch with whorls very tight in their coiling mode. This is not so in Tricolnaticopsis striatulus, which has a protoconch of the ordinary globular and rounded shape as usual among the Neritimorpha of St Cassian. Natica pseudospirata Orbigny, 1849 was characterized by Kittl (1892, pl. 7, fig. 43) as having a wider shell and less imprinted sutures, as in his Natica argus, which has colored dots that are typical for Tricolnaticopsis striatulus as documented by Zardini (1978, pl. 21, fig. 2). 


\section{Genus Pachyomphalus Böhm, 1895}

Type species. - The genus is based on Pachyomphalus concinnus Böhm, 1895 from the Marmolata Limestone.

Diagnosis. - Conical egg-shaped shell with a pointed apex about $6 \mathrm{~mm}$ high and rounded whorls with impressed sutures. Growth lines straight and body whorl occupies about two-thirds shell height. Aperture egg-shaped forming an apical angle. Umbilical area covered by callus of the inner lip. Outer lip rounded and inner lip slightly convex and smooth.

Differences. - Vernelia Böhm, 1895 is based on Natica excelsa Hauer from the Esino Limestone and it has a pointed-egg-shaped shell similar to that of Pachyomphalus, but is much larger (Wenz 1938-1944, fig. 982). Its aperture is oval with a flat callus of the inner lip that is slightly concave and smooth on its inner side. Vernelia differs from both Pachyomphalus and Tricolnaticopsis n. gen. in its concave inner lip.

\section{Pachyomphalus angustus (Münster, 1841)} Figure 9G-I, M, O

Diagnosis. - Shell wall thick and a little higher than wide. Outer shell wall consists of a thin calcitic layer and an inner shell wall that is aragonitic with crossed lamellar structure. Margin of the aperture is thick with the inner lip accompanied by a marginal groove; inner lip forms a median lobe that covers the umbilicus and produces a convex shape on the inner side towards the aperture. Inner walls of the shell not dissolved. Protoconch rounded consisting of three whorls which overlap with their margins.

Description. - The protoconch is about $0.4 \mathrm{~mm}$ wide with embryonic whorl succeeded by about two larval whorls which overlap onto each other. Their ornament is not pre- served. The shell of the teleoconch is thick. Its shape is obliquely egg-like with rounded whorls and weak sutures, with the three whorls of the teleoconch being about $3 \mathrm{~mm}$ high. The body whorl covers most of the first teleoconch whorl and only the protoconch extends over it in an apical direction. Ornament consists of growth lines with a low lobe below the suture and later on with a straight outline. The collabral lines form a pattern of fine regular grooves separated from each other by slightly wider smooth zones. The aperture is slightly inclined in relation to the shell axis and a little higher than wide; it is relatively small due to the thick callus of the inner lip and the convexity present in the middle of the edge. The outer lip is rounded, thickened, and smooth. In basal position the callus of the inner lip is accompanied by an outer groove that has a marginal rim. In median position the callus covers the umbilicus and continues to the apical corner of the inner lip. The callus ends before it reaches the outer lip. With two whorls of the teleoconch the shell is about $2 \mathrm{~mm}$ wide and $2.5 \mathrm{~mm}$ high, and the fully-grown shell consists of more than three whorls of the teleoconch and is about $5 \mathrm{~mm}$ high and $4 \mathrm{~mm}$ wide.

The thin outer calcitic layer of the shell has a well developed "ice flower" pattern formed by thin crystallites of calcite spread out with general direction of their apices toward the aperture. Shell walls are composed predominantly of a thick aragonitic layer in crossed lamellar structure. In cases where the color pattern is preserved, it consists of small irregular dots of light color on a dark background.

No operculum has been found in situ, but an operculum that would fit into the aperture according to shape and size is thick, with an oval, bean-like shape and having a convex outer surface. The side that lies next to the inner lip forms a low sinus. The eccentric nucleus lies near the outer edge and is the center to which concentric lines with different thickness are added. The inner side of the operculum is occupied by two pits separated by a broad ridge between them which is developed on the inner side. The inner surface is thus divided into two unequal fields (Zardini 1978, pl. 21, fig. 12).

Figure 9. A - apical view of Tricolnaticopsis striatulus (Münster, 1841) with the same shell as seen in side view in Fig. 9B (BSPG 2007 XVI 58). - B - side view of Tricolnaticopsis striatulus (Münster, 1841). Same shell as that showing shell structure in Fig. 9N. The shell is about 8 mm high. - C - fully-grown Pachyomphalus uhligi (Kittl, 1892) is about 9 mm high (BSPG 2007 XVI 59). D - the same shell as in Fig. 9C, Pachyomphalus uhligi (Kittl, 1892). E - a more juvenile shell of Pachyomphalus uhligi (Kittl, 1892) with the callus less expanded than in C. The shell is about 8 mm high (BSPG 2007 XVI 60). • F - Pachyomphalus uhligi (Kittl, 1892) as in Fig. 9E with a shell about 6 mm high. View from behind. • G - the shell of Pachyomphalus angustus (Münster, 1841). Shell about $3 \mathrm{~mm}$ high, its apex is shown in Fig. 9I (BSPG 2007 XVI 61). • H - Pachyomphalus angustus (Münster, 1841) with bulging inner lip and shell as in Fig. 9O. The shell is about $2.5 \mathrm{~mm}$ high (BSPG 2007 XVI 62). • I - the apex of the shell of Pachyomphalus angustus (Münster, 1841) shown in Fig. 9G with a rounded protoconch and with about three whorls. $\bullet \mathrm{J}-$ Rinaldopsis ampezzana $\mathrm{n}$. sp. has strong and irregular increments of growth. The shell is a little inclined and was crushed, with diameter about 5 mm (BSPG 2007 XVI 63). $\bullet$ - slightly corroded Rinaldopsis ampezzana $\mathrm{n}$. sp. showing the wide callus of the inner lip. The shell is about $11 \mathrm{~mm}$ high (BSPG $2007 \mathrm{XVI} 64)$. $\bullet$ L - Rinaldopsis ampezzana n. sp. as in Fig. 9K seen from behind. $\bullet \mathrm{M}$ - apex of Pachyomphalus angustus as in Fig. 9I with the larval shell ending with a lobed outer lip and protoconch with three whorls about $0.4 \mathrm{~mm}$ wide. $\bullet \mathrm{N}$ - shell of Tricolnaticopsis striatulus (Münster, 1841) having a very thin calcitic outer layer with the increments of growth forming lamellae, and a thick inner crossed lamellar layer organized with the direction of its lamellae parallel to increments of growth on the margin of the outer lip. The shell is about $0.3 \mathrm{~mm}$ thick. $\bullet \mathrm{O}$ - this shell of Pachyomphalus angustus (Münster, 1841) has a thin continuous outer calcitic layer and the crossed lamellar layer below forming the bulk. The shell is about $0.3 \mathrm{~mm}$ thick. 


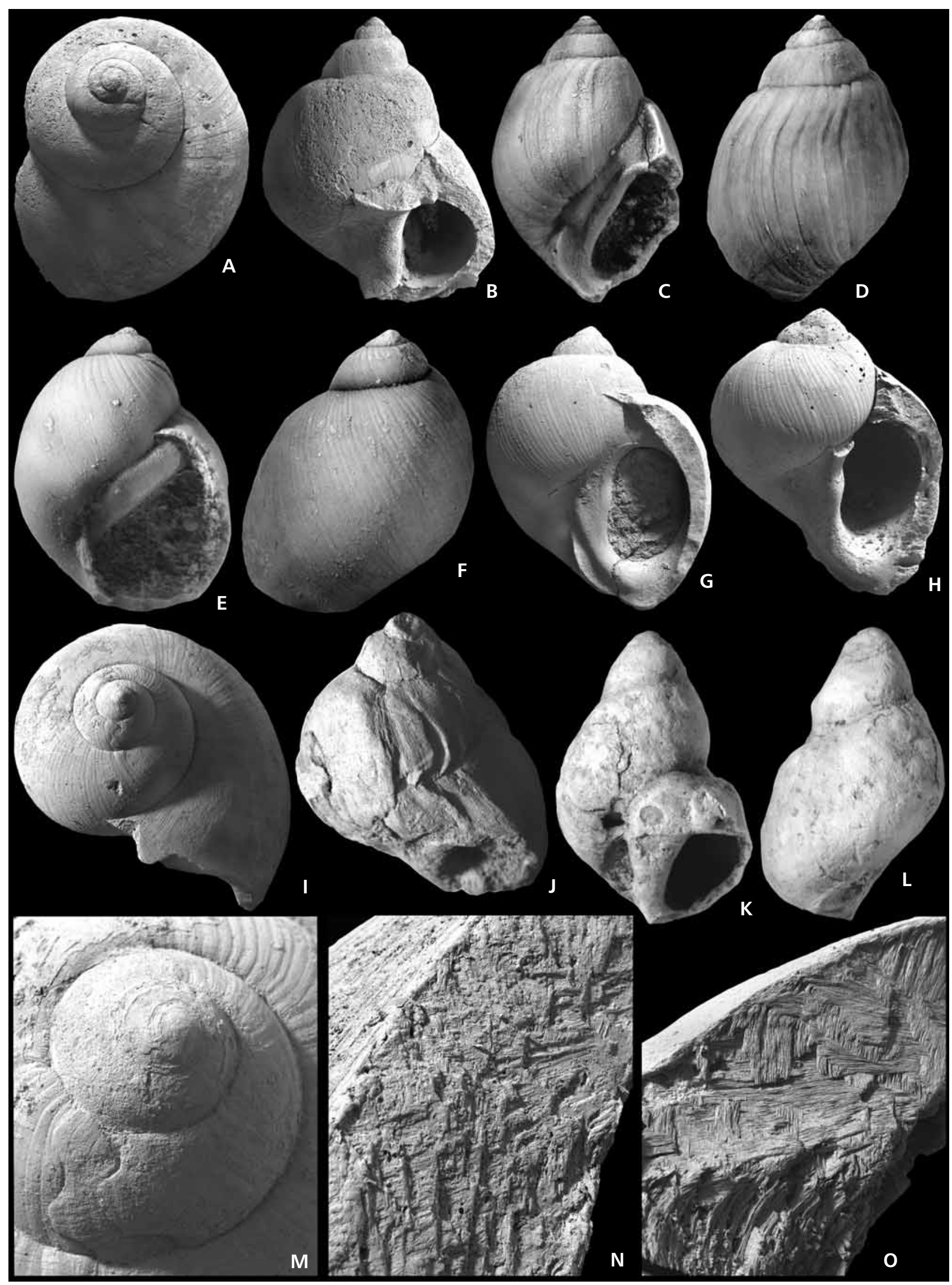


Differences. - The shell in Pachyomphalus uhligi and Tricolnaticopsis striatulus is higher and a little more elongate than that of Pachyomphalus angustus. Diener (1926) suggested that Pachyomphalus angustus, which he determined as Naticopsis kinkelini represents a member of Hologyra, but this is not confirmed. Pachyomphalus angustus differs from Hologyra cassiana by having a quite different shape of its callus and the umbilical groove and also by a higher and more pointed shell. The operculum that fits into the aperture of Pachyomphalus differs from that of other species from St Cassian by its elongate narrow bean-like shape.

Remarks. - This species was originally described as Natica angusta Münster, 1841, and illustrated again by Laube (1869) with the individual present in the collection at NHMW. It was later described as Naticopsis kinkelini Kittl, 1892 (Kittl 1892, pl. 7, fig. 25) and the same author also described and illustrated a Natica angusta based on a specimen that appears to represent juvenile shells of his Naticopsis kinkelini. A typical Pachyomphalus angustus was illustrated as Naticopsis kinkelini by Zardini (1978, pl. 20, fig. 1).

\section{Pachyomphalus uhligi (Kittl, 1892)}

Figure 9C-F

Diagnosis. - Egg-shaped shell has a smooth surface and well-expressed, but not deep sutures. Body whorl about four times higher than the spire. Callus of the inner lip forms a thickened elongate ribbon that covers the umbilical region and is accompanied on its basal portion by a narrow umbilical groove. Aperture oval with a convex inner lip.

Description. - The teleoconch consists of at least four whorls and the shell is about $10 \mathrm{~mm}$ high and $7 \mathrm{~mm}$ wide. It is covered by a thin but continuous outer calcitic layer and a thick inner aragonitic crossed lamellar layer. Here the largest lamellae are oriented parallel to the apertural margin. In case where preserved color patterns exist, they consist of fine brown zigzag lines in an axial orientation. The aperture is oval and relatively small. The inner lip is connected to the callus that covers the umbilical region. The callus is smooth and forms a ribbon that in old individuals has an elongate callus pad. The inner lip has a slightly convex shape. The outer lip is rounded with its margin at the base continuous with a shallow groove next to the base of the callus. The outer lip is narrower in fully-grown specimens than it is in juveniles.

Differences. - Tricolnaticopsis striatulus has deeper sutures, a relatively larger spire, a similar callus and outer shell layer, a different ornament of colored dots and a smoother outer surface. Pachyomphalus angustus (= kinkelini) is relatively shorter. A ribbon basal of the inner lip callus as in Pachyomphalus uhligi is not mentioned in the diagnosis of Vernelia (Wenz 1938-1944), and the shell of the latter is at least double the size of the former.

Remarks. - The specimen studied by Kittl (1892) was illustrated from the collection of NHMW. This shell is about $9 \mathrm{~mm}$ high and $6 \mathrm{~mm}$ wide with a Bithynia-like shape and the spire that is less than one fourth of the body whorl in height. Pachyomphalus uhligi had been suggested as Phasianella uhligi by Klipstein (in manuscript according to Kittl 1892) but was published as Naticopsis uhligi by Kittl (1892, pl. 7, fig. 26).

\section{Genus Rinaldopsis n. gen.}

Type species. - The genus is based on Rinaldopsis ampezziensis that is illustrated by Zardini (1978, pl. 31, fig. 3a, b) and determined as Oonia subtortilis from Alpe di Specie, St Cassian Formation.

Diagnosis. - Egg-like shaped shell with a pointed spire and body whorl about four times larger than earlier whorls. Aperture has a flat shelf-like structure on the inner lip encompassing about half of its size; shelf has a narrow and raised rim on the inner lip and extends into the narrow umbilicus.

Name. - The type to the genus was well documented by $\mathrm{Ri}$ naldo Zardini (1978) and is named in his honor.

Figure 10. A - juvenile shell of Tricolnaticopsis striatulus (Münster, 1841) with evenly rounded whorls and thick callus plate. Shell about 2 mm high (BSPG 2007 XVI 65). • B - juvenile shell of Rinaldopsis ampezziensis n. sp. with a $1.8 \mathrm{~mm}$ high shell and conical umbilicus (BSPG 2007 XVI 66). • C - juvenile shell of Laubopsis haudecarinata (Münster, 1841) with open umbilicus and about 1.5 mm in height (BSPG 2007 XVI 67). • D - Laubopsis haudecarinata (Münster, 1841) with rounded whorls and open umbilicus. Shell is 15 mm high (BSPG 2007 XVI 68). • E - Ladinaticella münsteriana (Orbigny, 1849) with a 5 mm high shell (BSPG 2007 XVI 69). • F - apical view of Ladinaticella münsteriana (Orbigny, 1849), same as in Fig. 10E. - $\mathrm{G}$ - protoconch of Ladinaticella münsteriana (Orbigny, 1849) with fine axial lines on the larval shell. Diameter about $0.5 \mathrm{~mm}$. $\bullet \mathrm{H}-$ juvenile shell of Ladinaticella costata (Münster, 1841). Shell about $1.4 \mathrm{~mm}$ high (BSPG 2007 XVI 70). • I - Ladinaticella costata (Münster, 1841). The same shell as in Fig. $10 \mathrm{H}$ in apical view with a rounded, smooth protoconch. $\bullet \mathrm{J}$ - Ladinaticella costata (Münster, 1841) with a $2.5 \mathrm{~mm}$ high shell (BSPG 2007 XVI 71 ). - K - Ladinaticella costata (Münster, 1841). The same shell as in Fig. 10J. • L - Ladinaticella striatocostata (Münster, 1841). Shell 10 mm high (BSPG 2007 XVI 73). $・$ M - Ladinaticella striatocostata (Münster, 1841). Shell $10 \mathrm{~mm}$ high. $\bullet \mathrm{N}$ - Ladinaticella striatocostata (Münster, 1841). Shell $10 \mathrm{~mm}$ high. 


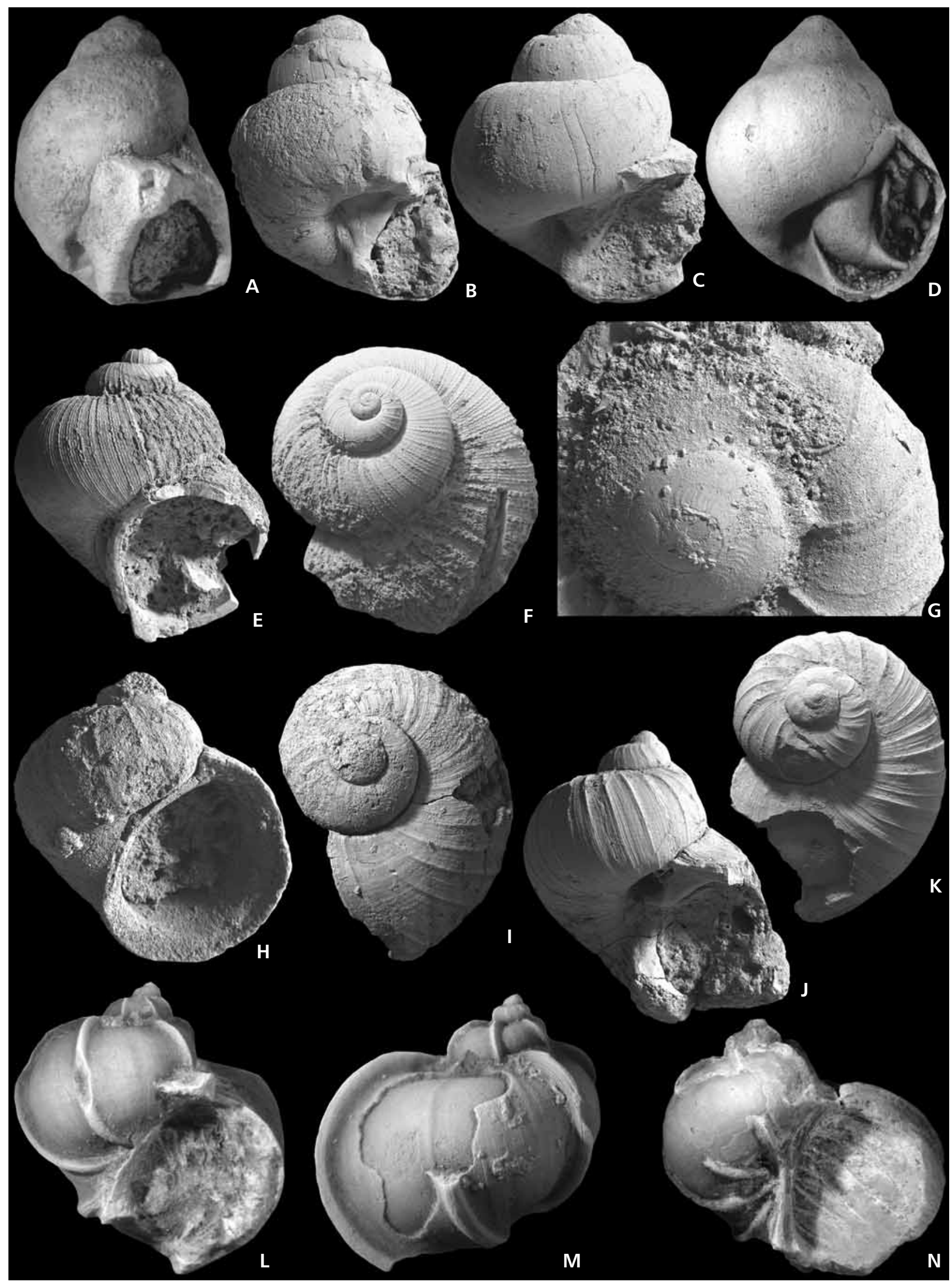


Comparison. - The aperture of Rinaldopsis resembles that of Pachyomphalus angustus that also has a rim at the edge of the callus to the inner margin of the inner lip. However, in regard to shell shape Rinaldopsis grows to a larger size.

\section{Rinaldopsis ampezziensis $\mathbf{n} . \mathbf{s p}$.}

Figures 9J-L, 10B

Holotype. - Specimen illustrated by Zardini (1978, pl. 31, fig. $4 \mathrm{a}, \mathrm{b}$ ) and deposited in the Ciasa de ra Regoles $\mathrm{Mu}-$ seum at Cortina d'Ampezzo.

Diagnosis. - Elongate oval shell has a flat and extremely broad callus of the inner lip. Shell consists of four whorls of the teleoconch evenly rounded in young individuals and more rugged with irregular growth lines in later age. Callus flat lying a little deeper than the margin to the oval aperture and extends into the umbilicus. A rounded ridge surrounds the umbilicus. No umbilical groove along the callus margin.

Description. - The shell has an oval shape with a pointed apex and is widest in the middle. Whorls increase rapidly in diameter. The aperture is rounded and on the inner lip is extended into a large flat callus plate. The ornament consists of strong often quite irregular growth increments (Zardini 1978, pl. 30, figs 13,14 , pl. 31, figs 3-5). The callus of the inner lip is quite characteristic. It consists of a flat plate that extends from the umbilical region to a margin formed by the edge of the inner lip. The size of the aperture is greatly decreased by this plate. The shell is relatively large, about $10 \mathrm{~mm}$ high, consisting of about four whorls of the teleoconch with a coarse growth line pattern. The whorls of the teleoconch are evenly rounded in young individuals (Zardini 1978, pl. 31, fig. 5), later acquiring a more rugged shape with irregular growth lines (Zardini 1978, pl. 30, fig. 13). The base is formed by a conical umbilicus that is open in juvenile shells with the callus entering it, becoming more or less hidden below the thick callus plate in more fully-grown shells.

Remarks. - The species determined by Kittl (1894) as Oonia subtortilis was based on Melania subtortilis Münster, 1841, but differs from individuals determined by Zardini (1978) as Oonia subtortilis by the callus of the inner lip. The general shape of the shell resembles that of Pachyomphalus uhligi, but Rinaldopsis ampezziensis differs by having a more flattened callus of the inner lip (Zardini 1978, pl. 30, figs 13, 14, pl. 31, figs 3-5).

The relationship of Rinaldopsis ampezziensis with other Neritimorpha from St Cassian Formation remains to be evaluated in detail, since neither the details of the protoconch nor the shape of the operculum are known. The operculum described under Pachyomphalus angustus would not fit well in the case of Rinaldopsis ampezziensis, since its inner lip is concave and not convex, which clashes with the bulging inner side of the operculum. The umbilicus is surrounded by a ridge and an umbilical groove is not present.

\section{Genus Laubopsis n. gen.}

Type species. - The genus is based on Natica haudcarinata Münster, 1841 from the St Cassian Formation.

Diagnosis. - Whorls of the shell evenly rounded and separated by deep sutures. Body whorl about three times larger than the height of the whorls forming the spire. Aperture has a simple and little thickened inner lip and a rounded outer lip. Umbilicus rounded and open. Shell consists of a thin calcitic outer layer and a thicker aragonitic inner layer in crossed lamellar structure.

Name. - This genus is called in honor of Gustav C. Laube who studied the gastropods of the St Cassian Formation.

\section{Laubopsis haudcarinata (Münster, 1841)}

Figure 10C, D

Diagnosis. - Shell with large rounded body whorls with a simple rounded aperture and open umbilicus. Protoconch consists of rounded whorls but detail unknown.

Description. - A $12 \mathrm{~mm}$ wide and $14 \mathrm{~mm}$ high shell has about 6 whorls of the teleoconch with a deep and relatively wide umbilicus. The outer shell layer is thin and of continuous calcitic construction. The inner shell layer is thick and consists of an aragonitic crossed lamellar structure in a uniform orientation with the lamellae parallel to the apertural margin. The shell surface is smooth with only fine growth lines. The aperture has an evenly rounded outer lip and a relatively narrow callus of the inner lip that ends at the margin and does not cover the umbilicus. The umbilicus continues in a groove to the base of the shell that is of conical shape and rounded. The protoconch consists of rounded whorls but is not well preserved.

Remarks. - A poorly preserved individual consisting of about 5 whorls of the teleoconch $(15 \mathrm{~mm}$ high and $12 \mathrm{~mm}$ wide) served for the description of Natica pseudospirata Laube, 1869 and was illustrated by Kittl (1892). However, the apertural area and umbilical region in this specimen are deformed, now representing a groove. A better preserved individual has been called Turbo orthostoma by Zardini (1978, pl. 11, fig. 3a, b).

The relation of Laubopsis haudcarinata with the other Neritimorpha of the St Cassian Formation remains undetermined since no characters except for the shape and construction of the teleoconch are know in any detail. 
Family Scalaneritinidae n. fam.

Type genus. - The family is based on Scalaneritina $\mathrm{n}$. gen. from the St Cassian Formation, and includes also the two species of Ladinaticella n. gen. and possibly also Lancedellopsis inaequiplicata.

Diagnosis. - Shell has an ornament of strong lamellar axial ribs and a simple straight or rounded aperture without grooves or teeth. Shell composition consists of a thin outer calcitic layer and a thick inner aragonitic layer with crossed lamellar structure. Inner whorls of the shell not dissolved. Protoconch consists of rounded whorls without ornament on its larval shell.

Remarks. - The species contained within the Scalaneritinidae have been previously placed within the Epitoniidae (Scalariidae, genus Scalaria), Naticidae (genus Naticella), genus Naticopsis and Trochidae (genus Eucycloscala); see Münster (1841), Laube (1869), Kittl (1892), Bandel (1993).

\section{Genus Scalaneritina n. gen.}

Type species. - The genus is based on the high-spired Scalaneritina triadica (Kittl, 1892; as Scalaria) from the St Cassian Formation, Alpe di Specie.

Diagnosis. - Conical shell has rounded whorls ornamented by few straight, lamellar axial ribs with a fine background of collabral lamellae between. Inner walls of the shell not dissolved and shell wall has an outer calcitic layer. Protoconch of conical shape and consists of few rounded whorls with impressed sutures.

Differences. - Scalaneritina is more conical and has a higher protoconch than is present in Ladinaticella.

Name. - The shell of Scalaneritina triadica resembles Epitonium Röding, 1789 (= Scalaria Lamarck), while protoconch, shell construction and the shape of the inner lip place the species here contained into the Neritimorpha. The shell structure and general shape resembles that of species found among modern Neritina. Scalaneritina is a free combination of generic names Scalaria and Neritina.

\section{Scalaneritina triadica (Kittl, 1892)}

Figure 11H-M

Diagnosis. - Elongate conical egg-shaped shell with widely spaced axial ribs and a simple aperture. Protoconch has a conical shape with rounded whorls. Thin calcareous operculum apparently of semicircular shape.
Description. - The holotype preserved in the NHMW collection retains the remnants of a thin calcareous operculum, but the latter is only preserved fragmentarily. The protoconch is succeeded by more than three whorls of the teleoconch. The shell is higher than wide, and turreted. The teleoconch has an ornament of lamellar axial ribs of which 5-7 are present on each whorl. They represent former stages of interrupted shell growth (varices). The outer lip is rounded and the inner lip almost straight. The callus of the inner lip narrows in the apical direction and widens to cover the umbilicus and continues as a flat ribbon to the base. In the umbilical region the ribs of the shell end without an umbilical groove being present. An operculum of calcareous, probably calcitic composition is preserved in one individual (NHMW) that appears to have some kind of projection on its apical side and a smooth surface on the larger basal side. The shell is about $6 \mathrm{~mm}$ high and slightly less in width.

Remarks. - The species is relatively common at the locality Alpe di Specie (Seelandalpe). The species was interpreted to represent Scalaria triadica by Kittl (1892, pl. 8, figs 34, 35), and also by Broili (1907, pl. 10, fig. 8) and to belong to the Scalariidae Lamarck, 1812 (= Epitoniidae Berry, 1910). It was later considered to represent a member of the Archaeogastropoda (Eucycloscala Cossmann, 1895). The species was documented by Zardini (1978, pl. 17, figs 8-10) as Eucycloscala triadica. Bandel (1993) recognized that it is not related to Eucycloscala, since neither the protoconch is similar nor is the shell structure nacreous, as is the case of true species of Eucycloscala. The holotype of Scalaria triadica from Alpe di Specie was studied from the collection at NHMW and clearly represents this species.

Kittl (1892) suggested a relationship with Naticella striatocostata. The species placed here in Ladinaticella costata differs from Scalaneritina triadica in having an open umbilicus, having fewer axial ribs and a lower, relatively broader shell.

\section{Genus Ladinaticella n. gen.}

Type species. - The genus is based on Ladinaticella münsteriana with a rounded shell in which the whorls have simple, straight, broad axial ribs with many fine ones in between. Also included are the species Ladinaticella striatocostata with a similar rounded shell, but an ornament of widely spaced axial ribs and a pointed apex, and Ladinaticella costata with a similar shape of the shell as in Ladinaticella striatocostata, but having an ornament more like that of Ladinaticella münsteriana.

Diagnosis. - Shell about as high as wide consisting of three rounded whorls of the teleoconch with a straight axial orna- 
ment. Protoconch rounded with whorls strongly overlapping each other. Aperture of the teleoconch rounded with a straight inner lip and callus formed by a narrow ribbon that covers the umbilicus; no umbilical groove.

Differences. - Ladinaticella has convergent shape with Scalaricopsis, which has an inner lip with a central angular depression and a furrow in continuation of the umbilicus on which the ribs of the teleoconch end. In contrast, in Ladinaticella the ribs end in the umbilicus and the lip is smooth.

Name. - These species had been placed in the genus Naticella by Kittl (1892) and others and they come from the Ladin, a region of northern Italy. The name of the genus Ladinaticella represents a free combination of both terms.

\section{Ladinaticella münsteriana (Orbigny, 1849) Figure 10E-G}

Diagnosis. - Rounded shell wider than high with ornament of many lamellar, axial ribs with a fine pattern of axial and spiral lines in their interspaces, and a simple round aperture. Umbilicus narrow and the ribs end in it. Lowly spire rounded at its top and holds the rounded protoconch consisting of about 2.5 whorls. Transition into the teleoconch indistinct, and teleoconch consists of three whorls.

Description. - The shell is broadly egg-shaped with a low rounded spire with a smooth protoconch in its center. Sutures are deep and whorls rounded. Inner walls of the shell are preserved. The shell is wider than high and when around $10 \mathrm{~mm}$ in width and $8 \mathrm{~mm}$ in height, it consists of about three whorls of the teleoconch. The ornament consists of lamellar ribs that are close to each other and have flattened interspaces further ornamented by a pattern of fine straight axial and spiral lines. The axial ribs are arranged more irregularly and develop into strong growth in- crements on the body whorl. The aperture is almost circular with the callus of the inner lip not wide but covering much of the umbilicus. The ribs of the ornament disappear below the umbilical callus cover. No groove is connected to the umbilicus. The inner lip is concave and smooth inside.

Differences. - Ladinaticella münsteriana resembles in shell shape Colubrellopsis acuticostata and have a very similar ornament. However, the latter species differs in having its characteristic inner lip of the aperture with a central depression and the umbilical furrow. Scalaneritina triadica has a much higher spire and coarser ribs, Ladinaticella costata has a more acute apex, but otherwise resembles $L a$ dinaticella münsteriana regarding the type of aperture and the ornament. Ladinaticella striatocostata also has a pointed spire and in addition has much wider spaces between its axial ribs.

Remarks. - Natica münsteriana of Laube (1869) represents one of the well-preserved specimens that had been determined as Naticella acutecostata by Kittl (1892). It is still found in the collection at NHMW. The species was originally described as Naticella acuticostata Klipstein, 1843 and was placed with Narica acuticostata or Narica münsteriana by Laube $(1869$, pl. 22, figs 8,10$)$. The other specimen illustrated by Kittl (1892, pl. 6, figs 22-24) represents Colubrellopsis acuticostata, since its inner lip has a Neritopsis-like character and the umbilicus marks the beginning of a narrow furrow that accompanies the inner lip to the base. Zardini (1978, pl. 20, fig. 5) illustrated as Naticella acutecostata a specimen of this species without umbilical furrow, and next to it (Zardini 1978, pl. 20, fig. 6a, b) Colubrellopsis acuticostata with an umbilical furrow and he determined both to represent the same species. They have very similar shell shape and ornament and can only be easily distinguished when the inner lip and the umbilical region are preserved. Natica (Narica) münsteriana Orbigny, 1849 in Laube (1869) appears to come closest to the species studied here.

Figure 11. A - Ladinaticella costata (Münster, 1841) with a $3 \mathrm{~mm}$ high shell (BSPG 2007 XVI 74). • B - the same shell as in Fig. 11A seen from the apex, with Fig. 11C showing details of the protoconch. $\bullet$ C - protoconch of Ladinaticella costata (Münster, 1841), about 0.6 mm wide, with an ornament of fine axial lines. $\bullet$ D - Lancedellopsis inaequiplicata (Klipstein, 1843) with the characteristic rounded tubercle in the aperture. Same as in Fig. 11E (BSPG 2007 XVI 75). • E - Lancedellopsis inaequiplicata (Klipstein, 1843) with relicts of a thin operculum in its aperture. Shell width about 2.5 mm. - F - the shell wall of Lancedellopsis inaequiplicata (Klipstein, 1843) has a relatively thick calcitic outer layer that is about 0.05 mm wide. - $\mathrm{G}$ - a protoconch of Lancedellopsis inaequiplicata (Klipstein, 1843) consisting of more than two smooth whorls and about 0.5 mm across. $\bullet \mathrm{H}-$ apertural view of Scalaneritina triadica (Kittl, 1892). Shell about $4 \mathrm{~mm}$ high (BSPG 2007 XVI 76). $\bullet$ I - Scalaneritina triadica (Kittl, 1892). Shell about 5 mm high (BSPG 2007 XVI 77). $\bullet \mathbf{J}$ - side view of Scalaneritina triadica (Kittl, 1892). Shell about 4 mm high. $\bullet \mathrm{K}-$ the smooth protoconch of Scalaneritina triadica (Kittl, 1892) is about $0.5 \mathrm{~mm}$ wide. $\bullet \mathrm{L}$ - the protoconch of Scalaneritina triadica (Kittl, 1892) is conical with rounded whorls and is about $0.4 \mathrm{~mm}$ high. $\bullet \mathrm{M}$ - the shell of Scalaneritina triadica (Kittl, 1892) has a very thin outer calcitic layer (inclined left side) and below it crossed lamellar structure. Shell less than $0.05 \mathrm{~mm}$ thick. $\bullet \mathrm{N}$ - protoconch of Neritaria mandelslohi (Klipstein, 1843) showing ornament and larval shell about $0.5 \mathrm{~mm}$ wide. Detailed view of Fig. 110 . $\bullet \mathrm{O}$ - juvenile shell of Neritaria mandelslohi (Klipstein, 1843) having a shell about $0.8 \mathrm{~mm}$ wide. Detailed view given in Figs 11P, 12C (BSPG 2007 XVI 78). P - Neritaria mandelslohi (Klipstein, 1843). The same shell shown in Fig. 11O, but seen from the side and showing the margin of the protoconch and the begin of the teleoconch from. The shell is $0.8 \mathrm{~mm}$ wide. 


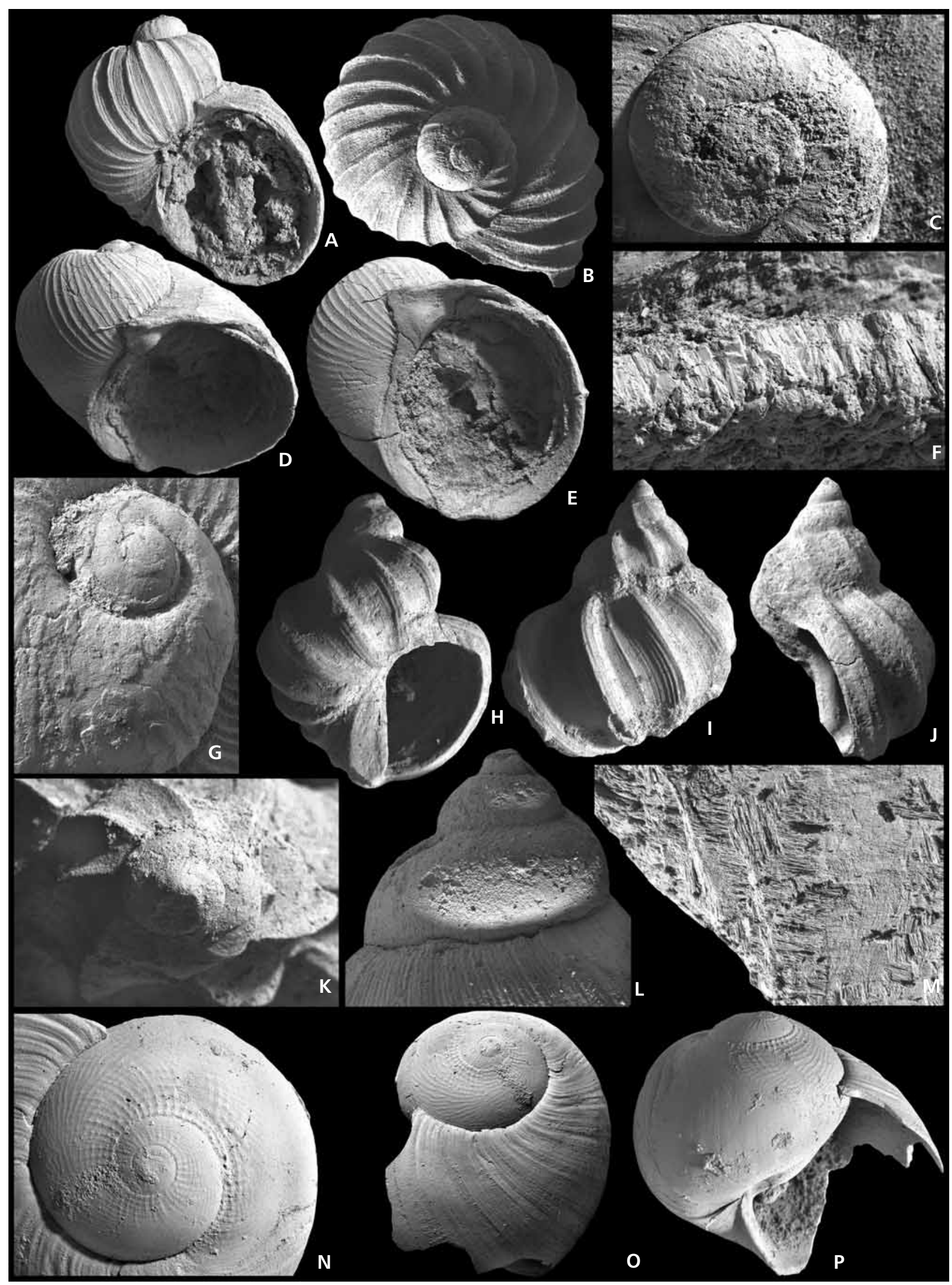


Ladinaticella costata (Münster, 1841) Figures 3J, 10H-K, 11A-C

Diagnosis. - Pointed egg-shaped shell as wide as high with an ornament of coarse axial ribs having many lamellar ribs in their interspaces, and a simple rounded aperture. Umbilicus narrow or closed, continuing in a very narrow but deep umbilical furrow that has collabral ribs ending at its sharp outer margin. Elevated conical spire containing a rounded protoconch of diameter about $0.6 \mathrm{~mm}$ wide consisting of 2.5 whorls. Larval shell ornamented with fine collabral ribs. Teleoconch consists of more than three whorls.

Description. - The shell is egg-shaped with a pointed spire and a size of $10 \mathrm{~mm}$ in width and height when consisting of more than three whorls of the teleoconch. Sutures are deep and whorls rounded. The inner walls of the shell are preserved. Ornament consists of lamellar ribs which are close to one another and have flattened interspaces with a pattern of fine straight axial lines. The aperture is round with a very narrow callus of the inner lip that still covers part of the umbilical slit, which continues in a narrow groove that ends on the base of the margin of the outer lip. The ribs of the ornament end in the umbilicus and the narrow groove beneath it. The inner lip is concave and smooth inside.

Differences. - Ladinaticella costata is shorter and has finer ornament than Scalaneritina triadica. In addition, the callus of the inner lip of the aperture is wider in the latter species. Ladinaticella münsteriana differs in having a shorter shell with a more rounded apex, and its ornament also has fine spiral elements besides the collabral elements.

Remarks. - The species comes closest to Naticella costata described by Zittel (1895, fig. 863). In the case of the description of similar shells by Kittl (1892), that of Naticella acutecostata includes individuals with a mostly low spire, but also such with an apex acute, and with a thin callus of the inner lip but also in other individuals, a wide one. It is thus quite possible that Kittl included within his description not only Ladinaticella münsteriana with almost flat apex, but also Ladinaticella costata with a pointed apex, as well as Colubrellopsis with a broad callus of the inner lip.

\section{Ladinaticella striatocostata (Münster, 1841) Figure 10L-N}

Diagnosis. - Relatively large rounded shell (15 mm high and wide) consisting of at least three whorls of the teleoconch. Ornament consists of strong, simple, widely spaced, lamellar axial ribs that continue up to the callus cover of the closed umbilicus. No umbilical groove. Aperture has its inner lip straight and narrow with a smooth inner side.
Description. - The shell is widely rounded with low spire and deep sutures. Ornament consists of 5 to 11 axial ribs on each whorl. The aperture is large and semicircular with the inner lip almost straight and formed by a narrow, but even callus ribbon. The callus is not accompanied by basal furrow and it covers the umbilical region.

Differences. - Ladinaticella striatocostata resembles Ladinaticella costata in shape and size, but has an ornament of fewer and much stronger axial ribs and no thin umbilical groove next to the inner lip. It has been illustrated by Zardini (1978, pl. 20, fig. 7) as Naticella striatocostata.

Remarks. - Ladinaticella striatocostata resembles Colubrellopsis acuticostata, which differs primarily in the characters of the inner lip. They were confused by Kittl (1892) who found that the type material of Naticella striatocostata of Münster (1841) consisted of shells with a closed umbilicus, while Laube (1869), in contrast to his illustration, described a wide-open umbilicus. Such an individual was also described by Kittl (1892, pl. 5, fig. 24, pl. 6, figs 25-27), but cannot be seen in his illustrations. Ladinaticella striatocostata has its inner lip bearing a narrow callus throughout, while that of Scalaricopsis acuticostata is accompanied by an umbilical groove next to the callus of the inner lip, the lip being wider, at its interior side also grooved and dented. Blaschke (1905, pl. 19, fig. 26) and Broili (1907, pl. 10, figs 9, 10) also described this species as Naticella striatocostata from the Seiser Alp.

\section{Genus Lancedellopsis n. gen.}

Type species. - The genus is based on Natica inaequiplicata Klipstein, 1843 as characterized by Kittl (1892) and newly studied from the St Cassian Formation.

Diagnosis. - Rounded shell with a short spire and very large body whorl. Aperture simple with a rounded outer lip and concave inner lip that has a rounded nodule on its inner upper side. Protoconch rounded and smooth. First whorl of the teleoconch has numerous collabral ribs and a deep suture. Next whorl having weaker collabral ornament. Callus ribbon of the inner lip covers the umbilicus with an umbilical groove at first narrow and later wide. Shell consists of a solid calcitic outer layer and an inner aragonitic layer of crossed lamellar structure.

Differences. - In ornament Lancedellopsis resembles Ladinaticella, but it differs from the latter genus by having more rapid increase in shell diameter, developing an umbilical groove, and having a rounded nodule in the upper part of the inside of its inner lip. The protoconch of Lancedellopsis resembles that of Ladinaticella in shape, but its orna- 
ment is not well enough preserved for good comparison. It may be that Lancedellopsis is not a member of the Scalaneritinidae, but represents another branch of the Cycloneritimorpha.

Name. - In honor of Rolando Lancedelli from Cortina d'Ampezzo who collected many of the gastropods that have been described by Rinaldo Zardini.

\section{Lancedellopsis inaequiplicata (Klipstein, 1843)} Figure 11D-G

Diagnosis. - Shell having a globular protoconch of $0.4 \mathrm{~mm}$ with about two whorls. Whorls of the teleoconch rapidly increase in width until the shell reaches $10 \mathrm{~mm}$ in height and width and consists of 2.5 whorls. Teleoconch ornament of collabral ribs, which within the second whorl may disappear. Aperture has the inner lip with a narrow callus ribbon that has a wider apical part with a rounded tubercle on its inner side. Umbilicus closed continuing in a groove. Operculum thin and of semicircular shape. Shell composed of a continuous and relatively thick calcitic outer layer with a layer of crossed lamellar structure beneath.

Description. - The shell is rounded and has a wide oblique aperture with a straight inner lip and an evenly rounded outer lip. The globular protoconch is not well preserved but appears to have been smooth. The first whorl of the teleoconch has an ornament of more than 40 simple collabral ribs that continue from the suture to the edge of the umbilical groove or the callus cover of the umbilicus in about the same composition. In the case of the original individual studied by Kittl (1892), present in the NHMW collection, the ornament on the second whorl of the teleoconch becomes weaker until only increments of growth remain. With 2.5 whorls of the teleoconch the shell is about $10 \mathrm{~mm}$ wide and high. The aperture has the inner lip expanded to form a callus ribbon that is narrow except in its apical part, where it covers the umbilical region. It is accompanied by an umbilical groove that increases in width with shell growth. In the fully-grown shell the groove shows growth increments, in a shell with only 1.2 whorls of the teleoconch it is very narrow. The aperture has a rounded thickening on the upper part of the inner lip. A partially crushed operculum is preserved, and is thin and similar to that of Ruganeritaria. However, in contrast to the latter genus its composition in regards to growth line patterns is not preserved.

Remarks. - Kittl (1892) compared Lancedellopsis inaequiplicata (as Naticopsis) with Colubrellopsis acuticostata (as Naticella acutecostata) and noted their resemblance. Kittl (1892) suggested that they could be best distinguished from each other by the ornament up to the body whorl. In
Colubrellopsis it is supposedly present and ornament is weaker on the body whorl in Lancedellopsis. This difference can no longer help, since such a change in ornament is also noted here in the case of Colubrellopsis acuticostata, where some individuals also have an almost smooth body whorl. The only solid difference between these species is in regard to the shape of the inner side of the inner lip, which was not noted by Kittl, and also not by Broili (1907). The inner lip has the character of Neritopsis in the case of Colubrellopsis, and is even and smooth in its lower portion and possesses a characteristic rounded nodule in its upper portion in the case of Lancedellopsis.

\section{Superfamily Neritoidea Rafinesque, 1815}

Diagnosis. - Inner walls of the whorls of the shell are dissolved during larval life and in most cases later. Protoconch whorls tightly coiled, convolute and composed of aragonite. Shell of the teleoconch has an outer calcitic layer and an inner layer composed of aragonitic crossed lamellar structure.

Remarks. - The central group of the Neritoidea is the Recent Neritidae still alive today. The most ancient known genera of the superfamily are represented by the Neritariidae from the St Cassian Formation.

Differences. - Among the living marine species with a shell, the only genus that does not belong into this superfamily and has the inner whorls preserved is Neritopsis of the Neritopsoidea.

Family Neritariidae Wenz, 1938

Diagnosis. - Globular shell composed of a very thin outer calcitic layer and a thick uniform inner aragonitic layer in crossed lamellar structure. Shell margin simple and sutures distinct. Aperture rounded with simple outer lip and inner lip with a bulging callus. Inner lip callus not continuous to the base, but ends in a depression with its outer margin a rib that connects to the base of the outer lip. Inner whorls of the shell dissolved. Protoconch globular with convolute whorls. Ornament of larval shell consists of rounded axial ribs and sometimes also fine spiral ribs.

Remarks. - The family is based on genus Neritaria Koken, 1892 from the St Cassian Formation. The family also includes Ruganeritaria and Dentineritaria forming the Neritariinae and Oncochilus and Cassianpisulina composing the Oncochilinae, and perhaps also Trachyneritaria of the Trachyneritariinae.

Description. - The larval shell of Neritariidae is of globular shape with distinct sutures, all whorls are visible and bear 
axial ornament. The aperture of the teleoconch has the inner lip with thickened callus that ends before reaching the base. From its basal end to the shell margin a ridge extends to the outer lip and delimits a narrow flat or slit-like area. The inner lip on its inner side carries one tooth (Neritariinae), or its margin projects into the aperture (Oncochilinae). Shell structure consists of a thin outer calcitic layer, with the bulk of the shell formed by aragonitic material in crossed lamellar structure arranged in lamellae that follow the outline of the outer lip.

Differences. - The shape of the shell of the Neritariidae from the St Cassian Formation resembles that of modern Neritina or Smaragdia but the shape of the callus of the inner lip of the teleoconch as well as the mode of coiling and ornament of the protoconch differ. Larval whorls overlap more strongly and are smooth except for very fine scratch-like axial lines in the Neritidae, Neritinidae and Phenacolepadidae. Neritariidae, in contrast, have all whorls clearly distinct and the larval whorls have an ornament of axial ribs. The callus of the inner lip of the teleoconch in Neritinidae forms a flat shelf, while it bulges into a median pad and ends before reaching the base in the Neritariidae.

Species of the Naticopsidae may have a similar shell shape, but do not dissolve their inner walls as is the case in the Neritoidea in general and also their family Neritariidae. The Cortinellidae are distinguished by their small shell coiled in one plane and ornamented by strong axial ribs (Bandel 2000, 2001). Among the Jurassic Neritoidea the species of Neridomus have the protoconch more globular than is the case in Neritaria and its relatives and it is more weakly ornamented (Bandel, personal data). Their teleoconch has a simple smooth inner side of their inner lip of the aperture. Neritidae often have a much thicker calcitic outer layer of their teleoconch, while it is very thin in the Neritariidae. The inner lip of the teleoconch in Neritidae and Neritinidae is often dented, but there are no teeth or ridges on the inner side of the inner lip. The Neritiliidae may also have a bulging callus of the inner lip (Pisulina) but their protoconch lies in an inclined position within the teleoconch, is ornamented by fine spiral lines or aligned grooves and composed of strongly overlapping larval whorls. These characters differ from those of the protoconch of the Neritariidae.

The operculum of Ruganeritaria resembles that of modern Nerita or Neritina, but it is hinged into the shell obviously aided by a tooth or ridge on the inner side of the inner lip. The operculum is also similar in shape to Neridomus from the Jurassic, but without connection to a tooth on the inner lip (Bandel, personal data).

The protoconch of Neritaria mandelslohi, Ruganeritaria subovata, Dentineritaria neritina, Oncochilus globulosus and Cassianpisulina bullata have a similar ornament of its larval shell consisting of low axial ribs, and a size that is around $0.5 \mathrm{~mm}$ and larger. Apertural features unite Neritaria mandelslohi and Runganeritaria subovata with a basal inner ridge, while Dentineritaria has a median inner tooth, Oncochilus Zittel, 1882 a two-lobed callus projection, and Cassianpisulina a median bulge; all four taxa show indistinct basal depression of the callus ribbon.

\section{Subfamily Neritariinae Wenz, 1938}

Diagnosis. - Shell rounded with smooth whorls and sometimes fold-like growth increments close to the suture. Inner whorls dissolved. Low, large, rounded protoconch has an ornament of low axial ribs on larval whorls. Outer layer of teleoconch very thin, calcitic, and with an acicular construction. Inner layer consists of an aragonitic crossed lamellar layer with the orientation of lamellae parallel to shell edge. Inner lip with a tooth on its inner side or a basal ridge.

Remarks. - The subfamily is based on the genus Neritaria Koken, 1892 with the type species Neritaria mandelslohi (Klipstein, 1843) from the St Cassian Formation.

Differences. - In this subfamily are included the genera $\mathrm{Ne}$ ritaria, Ruganeritaria and Dentineritaria, of which the first two have a protoconch of similar size of about $0.5 \mathrm{~mm}$, while that of the third is larger $(0.8 \mathrm{~mm})$ and has a shape consisting of more than 3 tightly coiled whorls, but with well-developed sutures. The genera differ from each other in regards to the ornament of their larval shell. In the case of Neritaria mandelslohi it consists of low collabral ribs crossed by spiral ribs that are best developed near the suture and the indistinct transition to the teleoconch. Ruganeritaria subovata has undulating axial ribs and a prominently rounded lobe on its outer lip. The larval shell of Dentineritaria neritina has straight axial ribs. Teleoconch differences also exist in the outer shell surface, being smooth in the case of Neritaria and Dentineritaria, while it consists of irregular wrinkles in Ruganeritaria. Apertural differences distinguish Dentineritaria with its tooth in a median position on the inner side of the inner lip, from the other two genera that have a tooth-like fold on the basal side of the inner lip.

\section{Genus Neritaria Koken, 1892}

Type species. - The genus is based on Natica mandelslohi Klipstein, 1843 from the St Cassian Formation.

Diagnosis. - First whorls of the teleoconch have an ornament of collabral wrinkles with fold-like growth increments that may occur close to the suture. Early teleoconch with globular shell; later growth stage Natica-like; finally 
ovoid in shape. Whorls smooth; body whorl abandoning regular coiling mode, twisting off and then having an inclined suture. Protoconch large and globular with larval whorls having a pattern of rounded axial ribs and spiral lines developed especially near the suture. Final part of larval shell also deviates from the coiling mode and has an inclined suture. Outer calcitic layer of teleoconch very thin. Inner lip forms a callus pad that covers the umbilical region; inner side with fold near the base that runs slightly inclined almost parallel to the inner lip.

Differences. - Only Ruganeritaria has a similar inner fold on its inner lip, but is quite distinct from Neritaria in having a folded shell surface, smaller size, and ornament on the larval shell.

Remarks. - According to Wenz (1938-1944, fig. 1002), the shell is Neritina-like. The genus is based on Natica plicatilis Klipstein, 1843 = Natica mandelslohi, which closely resembles Neritaria similis Koken, 1892 from the Upper Triassic Raibler Formation, Schlern-Plateau, Alps. Koken (1892) based his genus especially on Neritaria mandelslohi when he described Neritaria similis. Because of better preservation of specimens, Neritaria mandelslohi is here proposed to represent the type of the genus.

Kittl (1892) utilized Neritaria mandelslohi as the characteristic species to a group of St Cassian Natica. In the group he united species that have a callus pad of their inner lip which covers the umbilicus. The species of the group differ somewhat in the height of the spire, presence or absence of ornamental folds, as well as the width of the callus of the inner lip. Kittl (1892) also included into the group Natica angusta Münster, 1841, and Natica plicatilis Klipstein, 1843, which are not at all related to Neritaria, but represent relatives to Neritopsis, with the characteristic features of the inner lip of the aperture of that group (Fedaiella). Knight et al. (1960, fig. 183, 1) stated that Neritaria is a synonym to Protonerita Kittl, 1894 and characterized the shell as having a protuberance in the middle of its callus of the inner lip, but smooth inner side of the inner lip. The latter author suggested that the genus be based on Neritaria candida Kittl, 1894.

\section{Neritaria mandelslohi (Klipstein, 1843)}

Figures 11N-P, 12A-H

Diagnosis. - Juvenile shell globular, becoming helicoid and elongate ovoid shape when fully-grown. Spire short and pointed with axial folds. Callus of inner lip with a thickened median pad beneath which the columellar lip has a flat area with an outer ridge. Inner side with a fold near the base. Operculum generally Nerita-like. Protoconch measures about $0.5 \mathrm{~mm}$ and has an ornament of axial and spiral ribs.
Remarks. - Both the thickened median pad of the callus and beneath it the flat area with an outer ridge of the columellar lip are the same as in Ruganeritaria.

Description. - The shell has a rounded shape with a characteristic ornamental pattern of folds in axial orientation. The latter begin at the suture and decrease in strength or disappear further down on the whorls. With 1.7 whorls the teleoconch is globular in shape and measures $2.6 \mathrm{~mm}$ in height and $2.7 \mathrm{~mm}$ in width. Sutures are indistinct and the ornament consists of collabral elements that may be indistinct or quite distinct axial ribs. Shell shape is similar up to two whorls of the teleoconch, but in the third whorl the diameter increases more rapidly and the shape of the shell becomes more elliptical. The shell surface is smooth in the fourth (final) whorl of the teleoconch. Coiling mode deviates from the former whorls so that the suture is a little inclined. Maximum shell size is around $10 \mathrm{~mm}$ high and 8 to $9 \mathrm{~mm}$ wide. Shells of that size belong to fully-grown adult specimens as is indicated by the inclined suture and the callus pad of the inner lip, which is very strong and thick at that stage, more so than in earlier stages of growth. Color pattern of the shell is commonly preserved. It is quite variable with zigzag axial lines of dark and light color and spiral lines such as four narrow, brown ribbons. Some individuals have rows colored dots, others a uniform coloration of brown.

The aperture has a straight corner of the inner lip and an evenly rounded outer lip. Its orientation is oblique. The edge of the outer lip continues in a narrow rim into the umbilical area, and ends under the cover of the callus of the inner lip. The area between this rim and the basal part of the inner lip is flattened. The callus band expands above the umbilical region into a rounded pad. An internal fold lies next to the base on the inner side of the inner lip; the hinge of the operculum fitted in the groove between this tooth-like ridge and the inner lip but the ridge is not continuous into the shell interior. The operculum resembles that of Ruganeritaria in shape, and is thin with a smooth surface. Only fragmentary preservation was noted, though.

The protoconch is up to $0.6 \mathrm{~mm}$ wide and consists of more than three whorls. It is partly covered by the teleoconch. The embryonic whorl is connected to more than two larval whorls which expand rapidly and are coiled in convolute manner. They are ornamented by undulating low axial ribs and spiral ribs. Both form a reticulate pattern that is best developed next to the suture. The spiral ribs are at first weak, later on the final whorl spreading out in a fan-like fashion. Sutures are not impressed but still distinct. The margin of the larval shell is sinuous and not thickened. Its transition into the teleoconch is quite indistinct. It is connected with the change of sinuous growth lines to straight increments of growth. 
Differences. - Neritaria mandelslohi is larger than Ruganeritaria but closely resembles it regarding the aperture and operculum. The irregular folded surface of Ruganeritaria and its more rounded shape when fully-grown distinguishes the genus. The tooth on the inner lip of the aperture is stronger and in more basal position than that of Dentineritaria neritina. Neritaria mandelslohi has its protoconch with a fine reticulate ornament and a row of nodes near the suture. This distinguishes it from the axial ornament of Dentineritaria as well as the undulating pattern of Ruganeritaria but even more so from living Neritina and Nerita, which have their protoconch with a smooth surface and ornament consisting of only very fine scratch-like straight axial lines. In addition, the whorls of their larval shell more strong overlap each other and their sutures are indistinct (Bandel 2001).

Remarks. - Laube (1869) discussed Natica mandelslohi Klipstein, 1843, characterizing it by the axial folds of its ornament. Its size of about $9 \mathrm{~mm}$ in height and possession of about 4 whorls in the teleoconch fits with the observations on the species. However, Laube (1869) did not note the inner fold on the base of the inner lip, which is characteristic to the species. In addition, Natica cassiana of Laube (1869, pl. 21, fig. 10) may belong to that species, as well as Neritaria mandelslohi of Kittl (1894) from the Marmolata Limestone. All of these were not described in sufficient detail especially in regards to the internal basal fold that is actually characteristic to the species. This fold is also not seen in the specimens that were illustrated and described by Kittl (1892, pl. 7, figs 31, 33) as Natica mandelslohi from the St Cassian Formation. Zardini (1978, pl. 19, figs 1-5) determined it as Neritaria mandelslohi (Klipstein), but also as Naticopsis cassiana (Wissmann) (Zardini 1978, pl. 19, fig. 15), Naticopsis limneiformis (Laube) (Zardini 1978, pl. 19, fig. 16), and Neritaria plicatilis (Klipstein) (Zardini 1978, pl. 19, fig. 22), all without mentioning the basal fold in the shell. But this tooth is well seen in the illustration of Zardini (1978, pl. 19, figs 5, 15; 1985, pl. 9, fig. 3). Shell shape and ornament is obviously very similar to Neritaria (Neritaria) plicatilis Klipstein, as illustrated by Wenz (1938-1944, fig. 1002), but that species was also characterized without details concerning its aperture. In the case of the Peruvian representatives of the genus Neritaria described by Haas (1953) from the Pucará Group, the color pattern is preserved as well as the little knob on the inner side of the inner lip. This was confirmed by Bandel (1994, pl. 5, fig. 15) in the case of Neritaria distincta Haas, 1953.

\section{Genus Ruganeritaria n. gen.}

Type species. - The genus is based on Ruganeritaria subovata (Münster, 1841) from the St Cassian Formation, which is very common in the fauna from the locality Alpe di Specie.

Diagnosis. - Globular shell consists of 3 whorls of the teleoconch. Protoconch is of about $0.5 \mathrm{~mm}$ in size and has its larval shell ornamented by rounded and undulating axial ribs. Outer calcitic layer of teleoconch very thin. Below the outer layer shell material originally contained much organic material, deeper down more solidly mineralized. Inner shell walls dissolved. Operculum concentric with hinge fitted into a groove formed by a basal tooth and the inner lip. Outer surface of teleoconch can be wrinkled. Callus of inner lip characterized by a rounded pad in a median position above the umbilicus.

Name. - This Neritaria-like member of the Neritoidea has characteristic wrinkles, = rugae in Latin, and the name is a combination of both terms.

Differences. - Ruganeritaria resembles Neritaria in several ways, but is very distinct in its wrinkled shell, which probably formed during diagenesis. The outer shell layers, especially of the outermost aragonitic part, held much organic shell material. When it was destroyed or decomposed

Figure 12. A-juvenile shell of Neritaria mandelslohi (Klipstein, 1843) with callus pad and basal tooth on the inner side of the inner lip in the aperture. Shell 4 mm wide (BSPG 2007 XVI 79). • B - shell of Neritaria mandelslohi (Klipstein, 1843) with characteristic inner lip, and basal tooth-like ridge. $3 \mathrm{~mm}$ wide shell (BSPG 2007 XVI 80). $\bullet$ C - ornamented larval shell of Neritaria mandelslohi (Klipstein, 1843), detailed view of Fig. $11 \mathrm{O}$, P. • D - internal walls of Neritaria mandelslohi (Klipstein, 1843) are totally dissolved in the apical shell part, here fractured (BSPG 2007 XVI 81). E - the outer calcitic shell layer forms a continuous sheet, with the crossed lamellar layer below displaying the arrangement of the lamellae parallel to the aperture. - F - juvenile shell of Neritaria mandelslohi (Klipstein, 1843) with its callus very similar to Ruganeritaria, but differing having a smooth shell. Shell about 2 m high (BSPG 2007 XVI 82). $\bullet \mathrm{G}$ - fractured shell of Ruganeritaria subovata (Münster, 1841) showing dissolved inner whorls. Shell 4 mm wide (BSPG 2007 XVI 83). $\bullet \mathrm{H}$ - shell of Neritaria mandelslohi about $0.08 \mathrm{~mm}$ thick and having a very thin outer calcitic layer, (upper side) and well organized crossed lamellar layer below. $\bullet$ I - protoconch of Ruganeritaria subovata (Münster, 1841) about 0.5 mm wide, ornamented by collabral ribs and having its margin fractured before the teleoconch formed (BSPG 2007 XVI 84). • J - wrinkled shell of Ruganeritaria subovata (Münster, 1841) with operculum still in place. Shell $5 \mathrm{~mm}$ wide (BSPG 2007 XVI 85). $\bullet \mathrm{K}$ - shell of Ruganeritaria subovata with an extremely thin outer calcitic layer (upper part) and crossed lamellar structure below. The shell is about $0.04 \mathrm{~mm}$ thick. $\bullet \mathrm{L}$ - operculum in the aperture of Ruganeritaria subovata (Münster, 1841 ) with a nucleus in the lower left corner (BSPG 2007 XVI 86). $\bullet$ M - shell of Ruganeritaria subovata (Münster, 1841) with wrinkles and basal tooth in the aperture. Shell about 2 mm high (BSPG 2007 XVI 87). • N - characteristic wrinkled surface of Ruganeritaria subovata (Münster, 1841). Shell about 2.8 mm wide (BSPG 2007 XVI 88). 


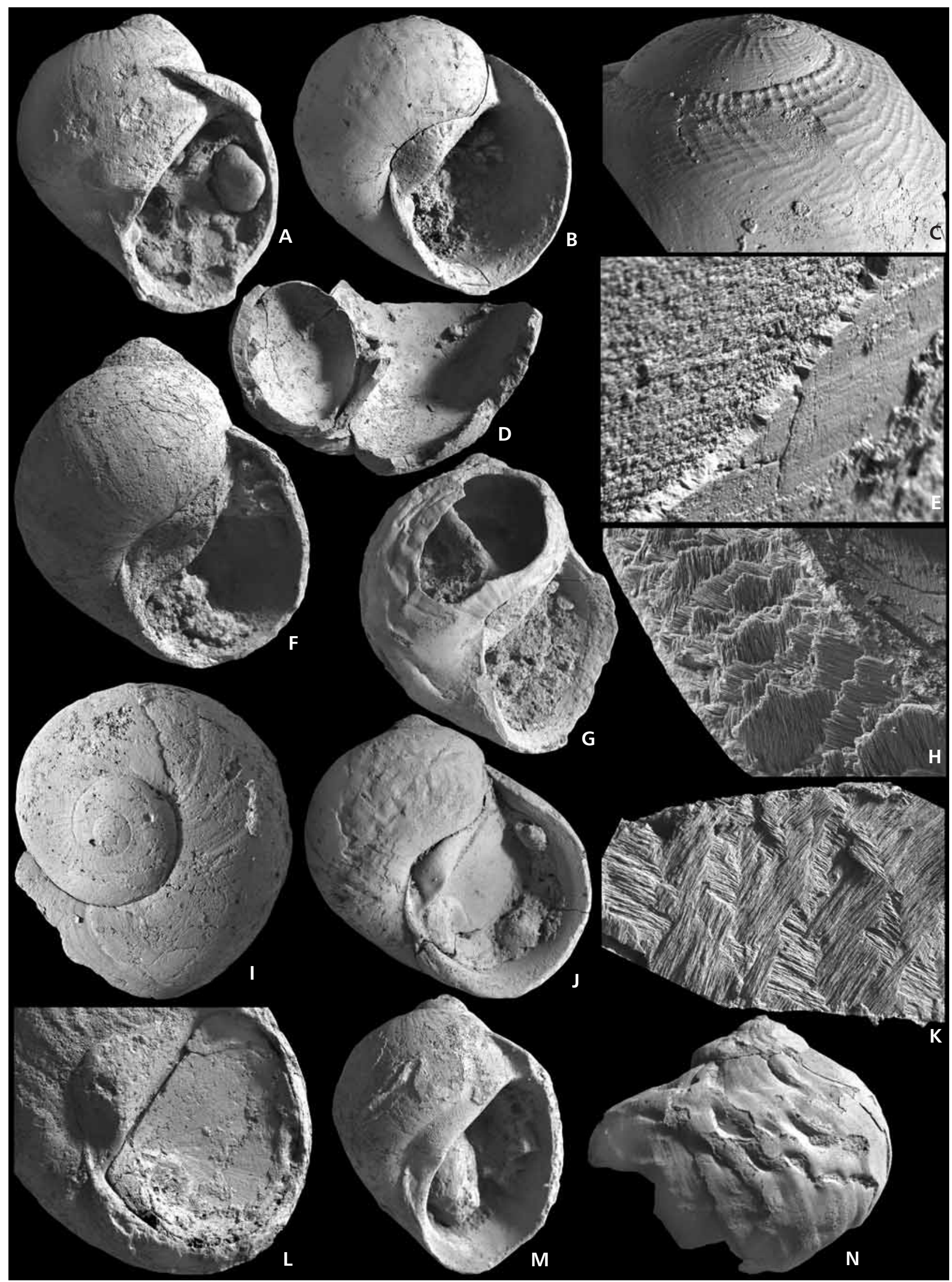


during earliest diagenesis, probably by microbial decay, the very thin calcitic layer on the shell surface collapsed locally during compaction of the sediment and formed wrinkles but these are not present in every individual shell. The construction of the operculum is like Recent Nerita or Neritina, but in contrast to these the hinge arrangement is different with a groove formed by a basal tooth and the inner lip.

\section{Ruganeritaria subovata (Münster, 1841)}

Figures 12G, I-N, 13K, L

Diagnosis. - Outer layer of shell transformed by folds of different orientation with layer below consisting of solid aragonitic crossed lamellar deposits. Rounded shell has a protoconch of 3 whorls with larval whorls having fine undulating axial ribs. Teleoconch consists of about 3 whorls either smooth or having collabral and irregular wrinkles. Inner lip granular with thick swelling in middle part that extends onto a thickened pad covering the umbilicus. Callus of fully-grown shells does not cover basal part of shell; here a ridge connects to outer lip. Inner walls of shell have been dissolved. Protoconch of more than three whorls with larval whorls ornamented by low undulating axial ribs and apertures with sinuous outline.

Description. - The oblique egg-shaped shell has thick walls with a very thin outer calcitic layer and massive aragonitic inner layer in crossed lamellar structure. A shell that is about $3.4 \mathrm{~mm}$ high and $3.3 \mathrm{~mm}$ wide has about 1.25 whorls of the teleoconch. With three whorls of the teleoconch the shell measures $6 \mathrm{~mm}$ in height and width and is fully-grown. The body whorls encompass almost the entire shell height and the sutures are indistinct. The final whorl has a more inclined suture. The pattern of growth lines may form shallow folds and an ornament of collabral folds or ribs. Folds of irregular orientation are usually also present. The aperture is large, oblique and semicircular in outline. Its outer lip is acute and thickened within. The inner lip forms a thick broad callus with a rounded pad near the umbilical region and a depression below it. The margin of the callus is formed by a thin keel that runs in a curve to the base. The callus surface is granular and its margin to the aperture is straight. A solid tooth lies near the base on the inner lip.

The protoconch is about $0.6 \mathrm{~mm}$ in diameter and partly covered by the first whorl of the teleoconch. The embryonic shell is succeeded by about two larval whorls. The final whorl declines a little. Ornament consists of low rounded axial ribs with an undulating somewhat granular pattern. There are about 30 axial ribs on a whorl with an inclined direction in collabral arrangement. The apertural margin has a wide lobe near the middle of the outer lip.
The operculum was preserved in place in several individuals, but usually crushed, since it is relatively thin. It fits with its straight inner margin to the straight edge of the inner lip. Its center of growth lies close to the basal inner lip. From the spiral nucleus growth lines go to the outer, rounded margin in a fan-like manner showing that growth was along the inner lip and faster towards the apex than towards the umbilicus. This growth is quite like that in the operculum of modern Neritina. The inner edge of the operculum is hinged into the groove formed by the tooth on the inner lip and the basal margin of that lip. A tooth on the inner side of the operculum cannot be made out but may be present.

Differences. - The whorls of Ruganeritaria subovata are more convolute and lower than Neritaria mandelslohi and Dentineritaria neritina. The inner lip callus of Ruganeritaria is wider than that of Dentineritaria neritina and Neritaria mandelslohi resembling in shape that of the latter species. The shell size of Ruganeritaria is smaller than that of Neritaria and larger than that of Dentineritaria.

The protoconch of Ruganeritaria in size and ornament resembles that of Neritaria mandelslohi and has similar axial but no spiral ornament, while the larval shell of Dentineritaria is larger and has straight axial ornament. The larval ornament of the protoconch of Cassianpisulina is quite similar to that of Ruganeritaria.

Remarks. - Laube (1869, pl. 21, fig. 8) noted a wrinkled surface in the species he had determined as Natica subovata Münster, 1841, a feature that is characteristic to many individuals of this species. However, his size data do not fit in all aspects; in 1869 Laube noted up to $9 \mathrm{~mm}$ in diameter, a size that would only fit with that of Neritaria mandelslohi. Zardini (1978, pl. 19, figs 8, 9) determined individuals of this species recognizable by their characteristic shell folds as Hologyra expansa, others as Naticopsis limneiformis Laube (Zardini, 1978, pl. 19, fig. 16), and others again as Naticopsis cassiana (Zardini 1978, pl. 19, fig. 19) and as Naticopsis impressa (Zardini 1978, pl. 19, fig. 20).

\section{Genus Dentineritaria n. gen.}

Type species. - Natica neritina Münster, 1841.

Diagnosis. - Small shell (about $6 \mathrm{~mm}$ wide and $5 \mathrm{~mm}$ high) with a characteristic tooth on inner side of inner lip in median position. Aperture large and whorls increase rapidly in width. Larval shell with ornament of axial ribs and consisting of three whorls reaching around $0.8 \mathrm{~mm}$.

Name. - This Neritaria-like member of the Neritoidea has a characteristic tooth, = dentis, "of a tooth" genitive in Latin, combined to give Dentineritaria. 
Remarks. - Shells shaped like Smaragdia which lives on sea-grass. Natica neritina Münster, 1841, according to Laube (1869) represents the smallest of the group of species from St Cassian. In the original description by Münster (1841) as well as the subsequent one by Laube (1869), this species could be fitted but Laube's illustration does not agree with it. Kittl (1892) determined it as Natica neritina, and the originals to his illustrations present in the NHMW collection in part have the characteristic median tooth on the inner side of their lip. This small central tooth was not described by Laube (1869) and is not found among the species described and illustrated by Zardini (1978). Since it occurs in the material that was in part collected and analyzed by Rinaldo Zardini it was most probably not recognized.

\section{Dentineritaria neritina (Münster, 1841) Figure 13A-H}

Diagnosis. - Ovoid shell with broad callus of inner lip with a groove on its basal end. Inner side of the inner lip carries a median tooth. Larval shell of large protoconch has an ornament of low rounded axial ribs. Teleoconch smooth.

Description. - Shell size is up to $6 \mathrm{~mm}$ high and $5 \mathrm{~mm}$ wide with only 2.5 whorls of the teleoconch. Whorls are smooth and increase rapidly in width. With one whorl of the teleoconch the shell is about $2.3 \mathrm{~mm}$ in width and $2.4 \mathrm{~mm}$ in height and has globular shape. The aperture is large, a little inclined, and almost semicircular in outline. The outer lip has an acute edge and is a little thickened on its inside. The callus of the inner lip forms a thickened ribbon that covers the umbilicus and connects with the outer lip on the apical side and ends before it reaches the basal side. Here a fine sharp keel connects with the edge of the outer lip at the base and differentiates a narrow flat area next to the basal outer lip. The surface of the callus is granular. In the middle of the inner lip and toward the interior of the aperture a small and distinct pointed tooth is developed. The inner walls of the shell have been dissolved.

The protoconch is $0.8 \mathrm{~mm}$ in diameter. Not all of it is visible in the apex when the first whorl of the teleoconch surrounds it. The embryonic shell is succeeded by 2.25 larval whorls that have an ornament of delicate axial ribs, which have a sinuous arrangement. 40 to 50 such ribs are present on the last whorl and the apertural margin is simple and straight.

Differences. - The small number of whorls of Dentineritaria neritina distinguishes it from Neritaria mandelslohi as well as from Ruganeritaria subovata both of which also have a tooth on their inner lip. However, their teeth are not in a median position as is the case in Dentineritaria neri- tina. The latter has a larger protoconch, a higher spire and a narrower inner lip than present in Ruganeritaria subovata and Neritaria mandelslohi. The teleoconch of Ruganeritaria commonly bears wrinkles, which are not found in Dentineritaria neritina.

Remarks. - The genus Cryptonerita Kittl, 1895 with a Natica-like shell having a smooth inner lip is based on Cryptonerita elliptica as illustrated by Wenz (1938-1944, fig. 1004). This is not the small Dentineritaria from the St Cassian Formation, but resembles Natica berwerthi Kittl, 1892, which is larger than Dentineritaria neritina. Kittl (1892) established Neritina imitans for a species from the St Cassian Formation, which has the shape of Dentineritaria, but differs in having the callus of its inner lip characterized as wide with a groove. No tooth on its inner side was noted. Study of the type of the species preserved in the collection at NHMW shows that it actually represents a member of the Oncochilinae with a projection of the margin of the inner lip into the aperture. Kittl (1892) discussed the possibility of Neritina imitans belonging to the modern $\mathrm{Ne}$ ritina, without coming to a final conclusion.

Subfamily Oncochilinae n. subfam.

Type genus. - The subfamily is based on the genus Oncochilus Zittel, 1882 from the Late Triassic.

Diagnosis. - Rounded shell with an ornament only of growth increments and a characteristic swelling on the inner lip, which in the case of Oncochilus consists of a double tooth, and in that of Cassianpisulina is a non-symmetric massive projection of callus of the inner lip, which ends before reaching the base. The groove formed below it has as an outer margin the continuation of the outer lip. Protoconch resembles that of the Neritariinae and has an axial ornament on its larval whorls.

Differences. - Here included are Oncochilus as well as Cassianpisulina from the St Cassian Formation. Oncochilus also has species in the Jurassic (Zittel 1873, 1895). The teleoconch of Cassianpisulina resembles modern Pisulina but differs from it in regard to the shape and ornament of the larval shell.

\section{Genus Oncochilus Zittel, 1882}

Diagnosis. - Rounded smooth shell with inner lip bearing two characteristic rounded tubercles in central part.

Type species. - According to Wenz (1938-1944, fig. 1010) the genus is based on Natica globulosa Klipstein, 1843, 
which is the same species as Natica subovata Münster, 1841 (Kittl, 1892) from the St Cassian Formation, Italian Alps.

\section{Oncochilus subovatus (Münster, 1841) Figure 14C, E-G}

Diagnosis. - Globular shell with four whorls in teleoconch and short spire. Two projections of callus plate of inner lip extend into apertural opening. Callus of inner lip forms a thickened pad over umbilical area; narrow umbilical furrow below which the outer margin fuses with edge of outer lip. Protoconch globular and about $0.5 \mathrm{~mm}$ in diameter.

Description. - The round shell with short spire and large body whorl has distinct sutures. In the last whorl of the fully-grown shell the suture is inclined. Growth lines have a curved outline. The outer calcitic layer may preserve a color pattern of zigzag lines and dots. A fully-grown shell with four whorls of the teleoconch may be up to $9 \mathrm{~mm}$ high and slightly less in width, but may also be about $8 \mathrm{~mm}$ high and $6 \mathrm{~mm}$ wide. Whorls are smooth. The semicircular aperture has a simple rounded outer lip, and a wide callus of the inner lip that expands into two strong folds on its inner edge. A thickened median pad with rounded outer margin forms a rounded bulging pad across the umbilical area. It does not expand to the apical and umbilical sides but covers only the middle of the shell on the inner lip and connects with the two projections into the median space of the aperture. On the basal side a ridge connects to the outer margin of the outer lip and an indistinct umbilical groove is developed here.

The protoconch is globular and consists of about 2.5 whorls of which only about $0.3 \mathrm{~mm}$ are visible at the top of the teleoconch, with much of it is covered. Larval shell ornament is not preserved but the size was at least $0.5 \mathrm{~mm}$ in width and height, as is seen in early juvenile shells.

Comparison. - A species of this genus from the Late Juras- sic described by Zittel (1895) as Oncochilus chromaticus has a less bulging callus pad (Zittel 1873), and a more indistinct umbilical groove, but otherwise is very similar to Oncochilus subovatus.

Remarks. - Natica globulosa was described as Deshayesia globulosa by Laube (1869, pl. 22, fig. 11) and placed with Oncochilus by Kittl (1892, pl. 6, figs 19-21) as in Zittel (1895, fig. 867, but here based on a Jurassic species). Kittl (1892) thought that the original of Natica subovata of Münster (1841) represents Oncochilus globulosus as described by Klipstein (1843). One of the original specimens of the illustration of Kittl (1892) is present in the NHMW collection and represents a fully-grown individual of this species, described by him as Oncochilus globulosus Laube. The two strong folds on its edge are documented in Laube's figure, which has also been reproduced by Koken (1897), Wenz (1938-1944, fig. 1010), and Knight et al. (1960). The species was called Neritodomus (Sphaerochilus) globulosus by Cossmann (1898). Zardini (1978, pl. 18, figs 9-13) illustrated individuals with one tooth on the edge of the inner lip as Oncochilus globulosus, but they actually represent Cassianpisulina. However, in his description of these specimens Zardini (1978) stated that there are two teeth projecting from the callus pad. In Zardini (1980, pl. 3, fig. 14) the two teeth on the inner lip are present and also the more rounded shell shape is evident, features characteristic of Oncochilus subovatus that also commonly has preserved color patterns. Knight et al. (1960, fig. 213, 5) illustrated an Oncochilus as it is in the species described here. They suggested placing it either with the Neritinae or with the Subilitacea.

\section{Genus Cassianpisulina n. gen.}

Type species. - The genus is based on Cassianpisulina bullata from the St Cassian Formation.

Diagnosis. - Rounded shell with thin outer calcitic layer

Figure 13. A - larval shell of Dentineritaria neritina (Münster, 1841) with ornament of straight regular axial ribs, detailed view to Fig. 13B. - B - protoconch of Dentineritaria neritina (Münster, 1841) with collabral ornament, detailed view given in Fig. 13A. The shell is about 1.2 mm wide (BSPG 2007 XVI 89). • C - juvenile shell of Dentineritaria neritina (Münster, 1841) with tooth on the inner lip, same shell as in Fig. 13A, B. • D - the callus of the inner lip of Dentineritaria neritina (Münster, 1841) has a granular surface in this detailed view to Fig. 13F. Picture about 0.7 mm high. $\bullet$ E - larval shell of Dentineritaria neritina (Münster, 1841) seen from the side with the transition into teleoconch. Shell width about 1.2 mm (BSPG 2007 XVI 90). $\bullet \mathrm{F}$ - shell of Dentineritaria neritina (Münster, 1841) is about $4 \mathrm{~mm}$ high. The tooth on the inner side of the aperture is seen in the middle of the inner lip (BSPG 2007 XVI 91). • G - structure of the shell of Dentineritaria neritina (Münster, 1841) with the calcitic layer (right side) underlain by crossed lamellar structure. Shell section about $0.05 \mathrm{~mm}$ wide. $\bullet \mathrm{H}$ - shell of Dentineritaria neritina (Münster, 1841) about $4 \mathrm{~mm}$ high and exposing the tooth on the inner lip (BSPG 2007 XVI 92). • I - shell of Cassianpisulina bullata (Koken, 1897) in apical view. Shell about 4 mm wide (detailed view given in Fig. 13J) (BSPG 2007 XVI 93). • J - protoconch of Cassianpisulina bullata (Koken, 1897) showing ornament of larval shell, detailed view to Fig. 13I. - K - protoconch of Ruganeritaria subovata (Münster, 1841) in juvenile shell about $0.6 \mathrm{~mm}$ in width. • L - protoconch of Ruganeritaria subovata (Münster, 1841) having a sinuous margin on its larval shell. Shell about 0.6 mm wide (BSPG 2007 XVI 94). • M - juvenile shell of Cassianpisulina bullata (Koken, 1897) with a shell about $1.5 \mathrm{~mm}$ high (BSPG 2007 XVI 95). $\bullet$ N - Cassianpisulina bullata (Koken, 1897) with an about 2 mm high shell (BSPG 2007 XVI 96). O - Cassianpisulina bullata (Koken, 1897) with a 2 mm wide shell and hollow interior (BSPG 2007 XVI 97). 


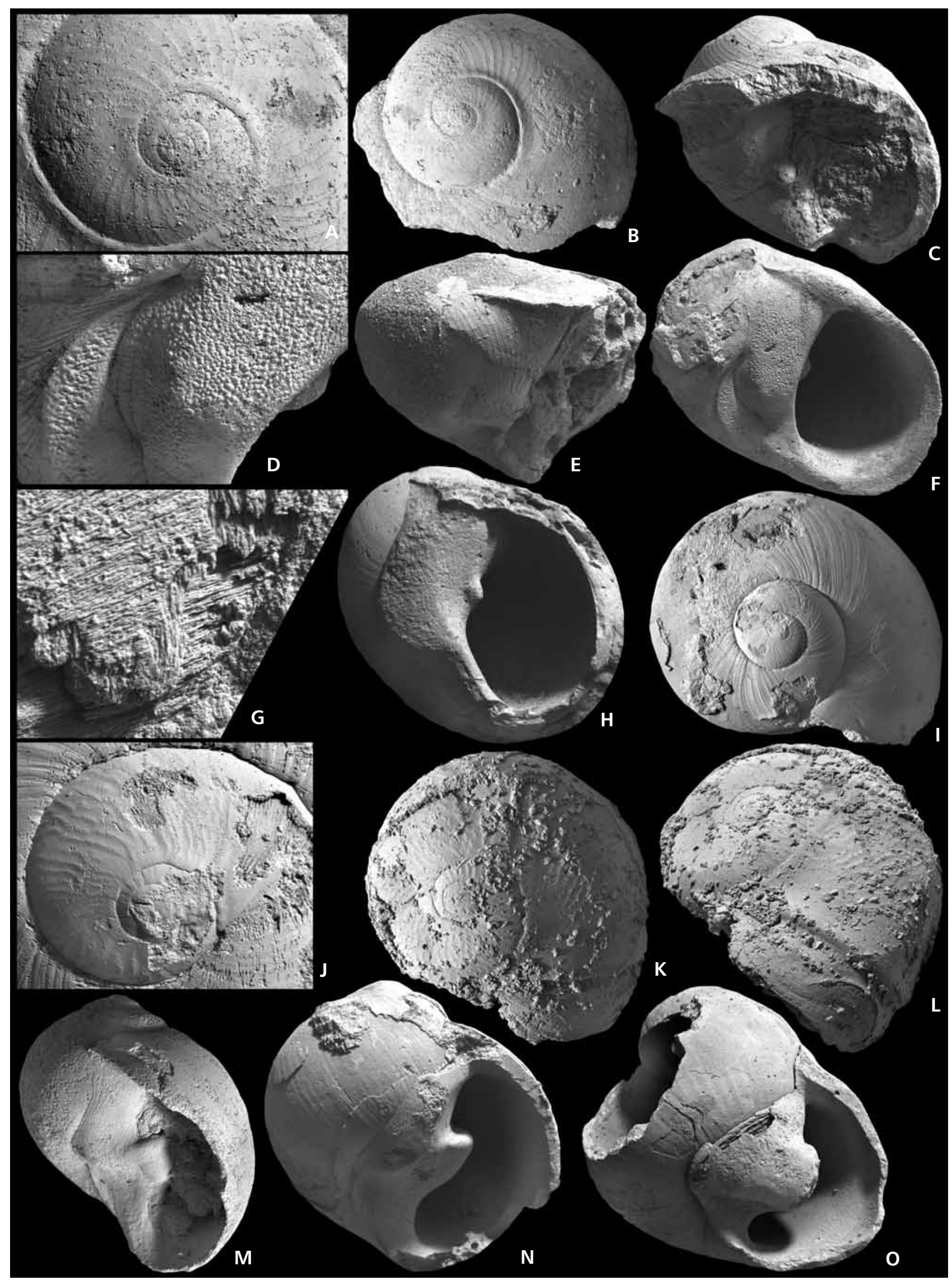


and thick uniform aragonitic inner layer composed of crossed lamellar structure. Callus of inner lip bearing a central projection as a continuation of the median pad with an angular shape on the apical side and a rounded form on its basal side. Protoconch globular, about $0.5 \mathrm{~mm}$ wide with low axial ribs on larval whorls.

Name. - The genus name is a combination of the place Cassian and a similar Recent genus, Pisulina.

Differences. - This round species from the St Cassian Formation has a similar shape to the living Pisulina, but differs in several details. The shell is of similar size to that of $\mathrm{On}$ cochilus, but is more ovoid and differs in the features of the inner lip. The type species is well documented by Zardini (1978, pl. 18, figs 9, 10) and determined as Oncochilus globulosus. Modern Pisulina has a similar teleoconch but a very different protoconch (Fig. 14H-J). It lies inclined in the teleoconch, has only a rudimentary ornament in the last part of its larval shell, and the larval whorls strongly overlap onto one another. In Cassianpisulina in contrast, the larval shell has an ornament of axial ribs, its whorls are tightly coiled but do not overlap as much and it is larger with clearly visible sutures.

Remarks. - Cassianpisulina bullata has been mistaken for Oncochilus globulosus by Zardini $(1978,1985)$ and Leonardi \& Fiscon (1959).

\section{Cassianpisulina bullata (Koken, 1897)}

Figures 13H, I, M-O, 14A, B, D

Diagnosis. - Globular shell having aperture with only one large rounded tooth in the middle of outer lip. Protoconch consists of 2.5 whorls with ornament on early larval shell of low axial ribs, and later larval shell smooth with a straight apertural margin.
Description. - The spire is low, whorls are strongly convolute, sutures little impressed. The inner lip has one thick median tooth. A fully-grown shell is about $9 \mathrm{~mm}$ high and $6 \mathrm{~mm}$ wide and has more than two whorls of the teleoconch. The callus of the inner lip extends from the apical margins of the outer lip across the region of the inner lip to the umbilical area. Here it is greatly thickened and extends in a bulging lobe with a steep apical side and rounded umbilical side projecting into the space of the aperture. On the basal side a ridge that is covered by the callus at the umbilicus is present and runs in a curve to the basal margin of the outer lip. This ridge separated an inner triangular sub-umbilical zone from the edge of the inner lip.

The protoconch is rounded and ends with the straight margin of its aperture. The 1.5 larval whorls have an ornament of low, sometimes branching axial ribs, which disappear near the aperture of the fully-grown protoconch that measures about $0.5 \mathrm{~mm}$ in diameter.

Color preservation occurs often as a dark brown background with spiral ribbons of lighter color, some with a zigzag pattern arising from the base.

Differences. - Cassianpisulina has a more bulging median thickening of its inner lip than is present in Pisulina. A basal ridge extending from the margin of the umbilical groove to the outer lip is not developed in the modern genus. The shell shape resembles that of Oncochilus globulosus but the aperture has only one large rounded tooth in the middle of the outer lip. In contrast to Oncochilus, the shell is more oval, the median callus more extended to the apical side and the projection into the aperture is not split into two teeth.

Remarks. - A specimen determined as Neritina imitans Kittl, 1892 from the NHMW collection that was used by Kittl (1892) for his illustration (not the type) actually represents a Cassianpisulina bullata with the projection of the

Figure 14. A - shell surface of Cassianpisulina bullata (Koken, 1897) with the calcitic layer at the right peeled off from the aragonitic layer with the lamellae of the crossed lamellar structure arranged almost parallel to the growth lines. Picture is about $0.25 \mathrm{~mm}$ wide at its base. $\bullet \mathrm{B}-$ the fractured shell of Cassianpisulina bullata (Koken, 1897) with the inner walls of the spire dissolved. The shell is 3 mm wide (BSPG 2007 XVI 98). • C - juvenile shell of Oncochilus subovatus (Münster, 1841) with a shell about $1.5 \mathrm{~mm}$ wide, reflecting the globular shape of the protoconch (BSPG 2007 XVI 99). - D - protoconch of Cassianpisulina bullata (Koken, 1897) less than $0.5 \mathrm{~mm}$ wide and having a smooth margin. At the beginning of the teleoconch the calcitic outer layer is developed, here corroded to demonstrate the elongate "frost pattern" crystallites. • E - Oncochilus subovatus (Münster, 1841) with a $3.5 \mathrm{~mm}$ wide shell and inner lip bearing two teeth (BSPG 2007 XVI 100). • F - Oncochilus subovatus (Münster, 1841) with a shell about 5 mm high (BSPG 2007 XVI 101). • G - partially covered protoconch of Oncochilus subovatus (Münster, 1841) about 0.3 mm across. $\bullet$ H - Recent Pisulina from the Gulf of Aqaba with a shell about $2 \mathrm{~mm}$ wide. $\bullet \mathrm{I}-$ the shell in Fig. 14I of Pisulina in apical view with the protoconch shown in Fig. 14J. $\bullet$ J - protoconch of Pisulina measururing about $0.2 \mathrm{~mm}$ across and lying inclined at the top of the teleoconch. It has an ornament of fine spiral lines and is largely covered by the teleoconch exposed. $\bullet \mathrm{K}$ - shell structure of Neridomus from the Jurassic of Madagascar with continuous thin outer calcitic layer and aragonitic crossed lamellar layer below. The illustrated layer is about $0.04 \mathrm{~mm}$ thick. $\bullet \mathrm{L}$ - apical view of Trachyneritaria nodifera (Kittl, 1895) with an angular periphery and a shell about measuring $1.5 \mathrm{~mm}$ in width (BSPG 2007 XVI 102). $\bullet \mathrm{M}$ - the fractured shell of Trachyneritaria nodifera (Kittl, 1895) shows that all inner whorls are dissolved. Shell about $1.5 \mathrm{~mm}$ wide (BSPG 2007 XVI 103). $\bullet \mathrm{N}$ - the protoconch of Trachyneritaria nodifera (Kittl, 1895) is rounded and low with several whorls and the teleoconch has indistinct spiral ornament and corners. The shell is 0.8 mm wide (BSPG 2007 XVI 104). 


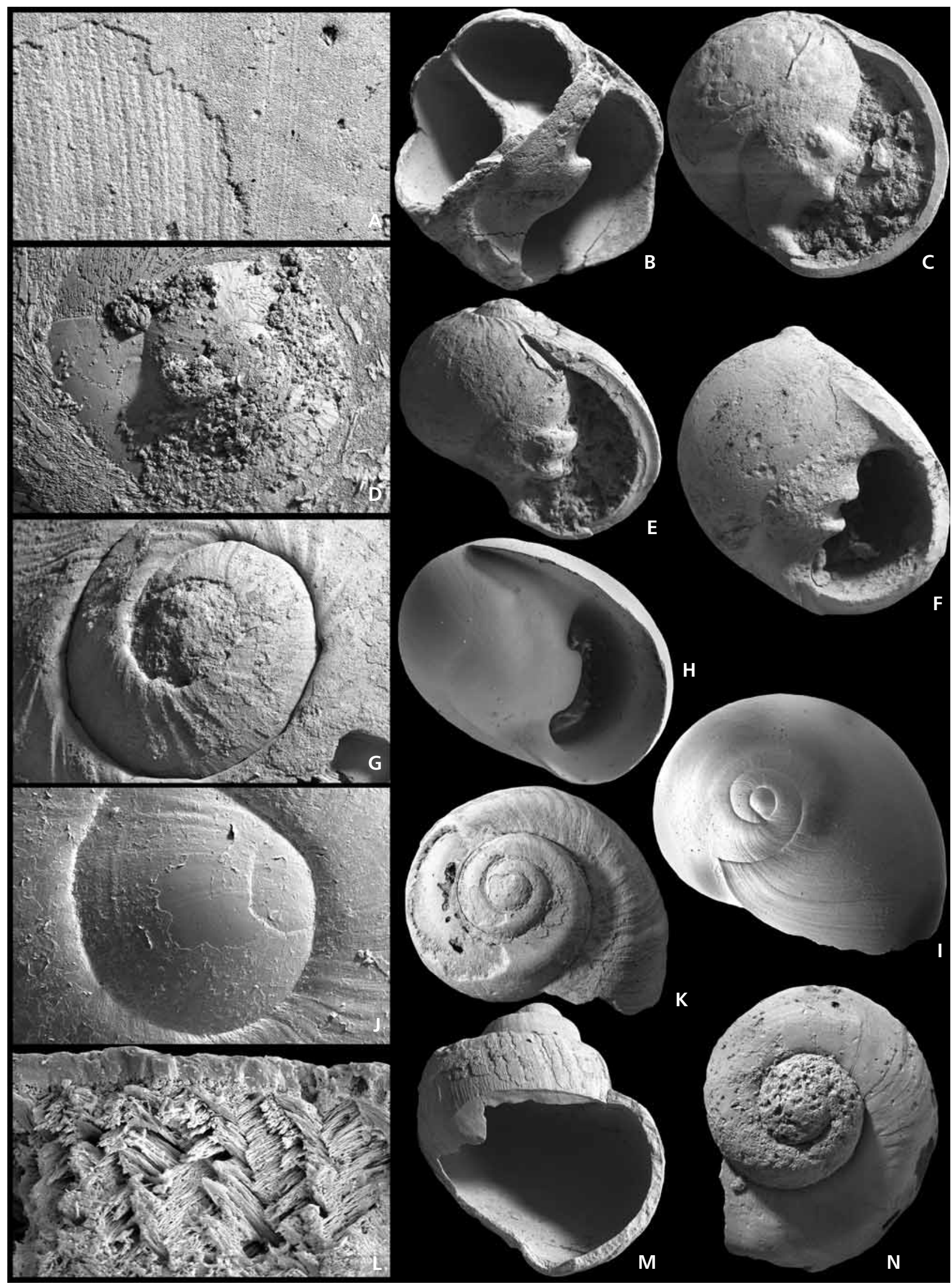


inner lip. However, in his description of the Neritina imitans Kittl (1892, pl. 8, figs 1,2) documents nothing of that median projection, so the species remains in doubt.

Subfamily Trachyneritariinae n. subfam.

Type genus. - The subfamily is based on Trachyneritaria $\mathrm{n}$. gen. from the St Cassian Formation, Alpe di Specie.

Diagnosis. - Teleoconch of angular shape with flattened apical ramp, rounded corner to the side and a few more or less distinct rounded spiral ribs. Inner whorls of the shell totally dissolved. Inner lip thickened and its inner edge convex. Callus forms a pad that ends near the base with an indistinct groove; its outer margin connected to the outer lip. Protoconch globular measuring about $0.3 \mathrm{~mm}$. Shell structure is crossed lamellar aragonitic with a very thin outer calcitic layer.

Differences. - Members of the Trachyneritariinae have the inner whorls of their shell totally dissolved, as is the case of the Neritariidae in general but they differ in the more angular shape of their teleoconch, the simple convex bulge of their inner lip, and the relatively small globular protoconch.

Remarks. - Existing information is limited for this group since protoconch ornament is unknown. The holotype to the genus Trachynerita Kittl, 1894 is a large shell of $30 \mathrm{~mm}$ in diameter, whereas the specimens studied here and referred to Trachyneritaria are small with a size range of 2 to $3 \mathrm{~mm}$ when fully-grown. Trachynerita as characterized by Knight et al. (1960, fig. 183, 16a, b) is a very different genus to the Trachyneritaria described below.

\section{Genus Trachyneritaria n. gen.}

Type species. - The genus is based on Trachynerita nodifera Kittl, 1894, originally from the Marmolata Limestone, Italian Dolomites, and as newly defined here is based on individuals from Alpe di Specie near Cortina d'Ampezzo (map in Zardini 1978, Wendt 1982, fig. 1).

Diagnosis. - Teleoconch with angular shoulder. Inner whorls of shell dissolved. Globular protoconch consisting of several (about three) rounded whorls.

Name. - The name of the genus represents a combination of the genus name Trachynerita (which has a similar shape but larger shell size) and Neritaria to which the described species is related. The small species is named with a combination of both: Trachyneritaria $\mathrm{n}$. gen.

\section{Trachyneritaria nodifera (Kittl, 1894)} Figure 14L-N

Diagnosis. - Small shell reaching $3 \mathrm{~mm}$ in size consisting of about four whorls in teleoconch. Inner whorls totally dissolved. Rounded protoconch consisting of a few (about three) convolute whorls and measuring about $0.3 \mathrm{~mm}$. Whorls of teleoconch with rounded corner on convex sides and rounded corner to the base. Additional spiral ornament may be present or absent. Aperture large with simple outer lip. Callus of inner lip forms rounded low pad that covers the umbilical area and ends before reaching the margins of the outer lip on apical and basal sides. Margin of outer lip continues onto the margin of a weak depression on the base ending in the median callus pad of the inner lip.

Description. - The shell with 2.5 whorls of the teleoconch is only a little more than $2 \mathrm{~mm}$ high and a little less wide with a blunt spire. A size of about $3 \mathrm{~mm}$ in width and height is attained in fully-grown shells containing four whorls of the teleoconch. The end of shell growth is indicated by the presence of dense growth increments in the final part of the body whorl. The protoconch of a little more than $0.3 \mathrm{~mm}$ in diameter has a simple apertural margin, and consists of several whorls with the ornament of the larval shell not preserved. First whorl of the teleoconch has a step-like shape. Whorl sides are weakly convex and end in a rounded corner on the convex base. A spiral rib may indicate the widest part of the whorl and where crossed by growth lines may have low tubercles. The sutures are deep. Collabral growth lines are present and may be strong. Additional spiral ribs may appear and disappear again in later whorls. The aperture is oval in shape and about twice as high as wide. The outer lip is simple with the apical corner expressed. The inner lip widens in the middle and covers the umbilical region with a callus. The inner side of the inner lip is weakly convex.

Differences. - Trachyneritaria nodifera may have nodular anterior and posterior edges and in general shape resembles Trachynerita. Its protoconch is smaller (about $0.3 \mathrm{~mm}$ in diameter) than that of the other Neritariidae of the fauna of the St Cassian Formation.

Remarks. - The genus Trachynerita Kittl, 1894 is based on Turbo quadrata Stoppani, 1858 = Trachynerita foronensis Kittl, 1894 from the Marmolata limestone, Italian Alps (Kittl 1894, pl. 3, figs 9-12; Böhm 1895, pl. 10, fig. 4). Turbo quadrata Stoppani, 1858 was originally described from Esino and Kittl (1899, pl. 2, figs 1,2) also recognized from that locality a Trachynerita fornonensis Kittl, 1895. Nützel \& Senowbari-Daryan (1999) described a species determined as Trachynerita quadrata from the Late Triassic of Iran that may even be up to $40 \mathrm{~mm}$ in size. This spe- 
cies placed in the Neritidae by the authors is not sufficiently well preserved to determine shell structure, protoconch shape or presence or absence of internal walls.

The type species of the genus Trachynerita has a much larger shell than the type to Trachyneritaria n. gen. as here described based on Trachyneritaria nodifera $(30 \mathrm{~mm}$ in contrast to $2-3 \mathrm{~mm}$ ). The latter has been introduced as Trachynerita nodifera Kittl, 1894 from the Marmolata limestone (Kittl 1894, pl. 3, figs 15, 16), and was described again by Böhm $(1895$, pl. 10, figs 1,2$)$ and mentioned by Cossmann (1925, pl. 9, fig. 44). It does not resemble Trachynerita as described by Knight et al. (1960, fig. 183, $16 \mathrm{a}, \mathrm{b})$, which has a strong spiral row of tubercles and is based on a different type species (Trachynerita depressa Hoernes, 1855). In the case of Trachynerita, color patterns of dark zigzag ribbons were noted by Kittl (1894). Zardini (1985, pl. 3, fig. 9a) illustrated Trachynerita quadrata and determined it as Naticopsis zitteli. Also Trachynerita tambosolensis Haas, 1953 from the Late Triassic of Peru (Haas 1953, pl. 11, figs 18, 19, 24) is similar. It has the rounded aperture with a simple inner lip that covers the umbilical region with a thick callus (Bandel 1994). From the St Cassian Formation, Trachynerita quadrata was determined by Leonardi \& Fiscon (1959, pl. 4, fig. 15), and also illustrated by Tichy (1980, pl. 4, fig. 18). Zardini (1978, pl. 10, fig. 16a-d) documented a shell resembling it in general shape as Turbo subcarinatus (Münster, 1841). It is up to $10 \mathrm{~mm}$ high and has color patterns preserved.

The shell of Trachynerita quadrata (Stoppani, 1858) has an apical angle and otherwise is of rounded outline (Wenz 1938-1944, fig. 1007). It resembles Trachynerita altoni (Kittl, 1892) that is present with its holotype in the NHMW collection and had originally been described as Naticopsis altoni by Kittl (1892, pl. 7, fig. 14). Its shell is of rounded outline with a short spire forming the shoulders and whorls and distinguished from each other by groove-like sutures. The body whorl is large and has a simple large aperture with a well-developed inner lip callus. Its shell is larger than that of Trachyneritaria nodifera and nothing is known about its internal composition.

\section{Acknowledgments}

Originally, Annette Schwardt (Hamburg) began this study supported by financial aid from a DFG project to revise the Neritimorpha from the Triassic St Cassian Formation in the vicinity of Cortina d'Ampezzo in the Italian Alps, but discontinued her work by end of 1994. She borrowed some originals from the Naturhistorisches Museum at Vienna (NHMW) from the studies of Laube (1869) and Kittl (1892) that have been included in this study. More recent material has been collected by the author (aided by his students) during several trips in the region of Cortina d'Ampezzo with localities pointed out by the late Rinaldo Zardini. Zardini and Rolando Lancedelli had collected in the area over many years and also provided some of the specimens that were studied here. Robert Welti and Ivonne Milker helped in documenting the material with the scanning electronic microscope. Photographs of specimens were made and plates assembled by Eva Vinx. Marlies Becker helped in handling the manuscript during its production. I also thank Robert B. Blodgett and Alexander Nützel for their thoughtful reviews of the manuscript and Susan Turner for revising the English.

\section{References}

BANDEL, K. 1982. Morphologie und Bildung der frühontogenetischen Gehäuse bei conchiferen Mollusken. Facies 7, 1-198.

BANDEL, K. 1988. Repräsentieren die Euomphaloidea eine natürliche Einheit der Gastropoden? Mitteilungen aus dem Geologisch-Paläontologischen Institut der Universität Hamburg 67, 1-33.

BANDEL, K. 1990. Shell structure of the Gastropoda excluding the Archaeogastropoda, 117-134. In CARTER, J.G. (ed.) Skeletal Biomineralization: Patterns Processes and Evolutionary Trends. Volume I. Van Nostrand Reinolds, New York.

BANDEL, K. 1993. Trochomorpha aus der triassischen St. Cassian Formation (Gastropoda, Dolomiten). Annales des Naturhistorischen Museums in Wien 95, 1-99.

BANDEL, K. 1994. Comparison of Upper Triassic and Lower Jurassic gastropods from the Peruvian Andes (Pucará Group) and the Alps (Cassian Formation). Palaeontographica 233A, 127-160.

BANDEL, K. 1997. Higher classification and pattern of evolution of the Gastropoda. A synthesis of biological and paleontological data. Courier Forschungsinstitut Senckenberg 201, 57-81.

BANDEL, K. 2000. The new family Cortinellidae (Gastropoda, Mollusca) connected to a review of the evolutionary history of the subclass Neritimorpha. Neues Jahrbuch für Geologie und Paläontologie, Abhandlungen 217(1), 111-129.

BANDEL, K. 2001. The history of Theodoxus and Neritina connected with description and systematic evaluation of related Neritimorpha (Gastropoda). Mitteilungen aus dem Geologisch-Paläontologischen Institut der Universität Hamburg 85, 65-164.

BANDEL, K. 2002. Reevaluation and classification of Carboniferous and Permian Gastropoda belonging to the Caenogastropoda and their relation. Mitteilungen aus dem GeologischPaläontologischen Institut der Universität Hamburg 86, 81-188.

BANDEL, K. \& FRÝDA, J. 1999. Notes on the evolution and higher classification of the subclass Neritimorpha (Gastropoda) with the description of some new taxa. Geologica et Palaeontologica 33, 219-235.

BANDEl, K. \& HeIdelberger, E. 2001. The new family Nerrhe- 
nidae (Neritimorpha, Gastropoda) from the Givetian of Germany. Neues Jahrbuch für Geologie und Paläontologie, Monatshefte 2001(12), 705-718.

BANDEL, K. \& KIEL, S. 2003. Relationships of Cretaceous Neritimorpha (Gastropoda, Mollusca), with the description of seven new species. Bulletin of the Czech Geological Survey 7, 53-65.

BiggelaAR, J.A.M. van DEN \& HASZPRUNAR, G. 1996. Cleavage patterns and mesentoblast formation in the Gastropoda: an evolutionary perspective. Evolution 50, 1520-1540.

BlaschKe, F. 1905. Die Gastropodenfauna der Pachycardientuffe der Seiseralpe in Südtirol nebst einem Nachtrag zur Gastropodenfauna der roten Raibler Schichten vom Schlernplateau. Beiträge zur Paläontologie und Geologie Österraich-Ungarns und des Orients 17, 161-222.

Blendinger, W. \& Blendinger, E. 1989. Windward-leeward effects on Triassic carbonate bank margins in the Dolomites, northern Italy. Sedimentary Geology 64, 143-166.

Blodgett, R.B., FrÝdA, J. \& Stanley, G.D. 2001. Dephinulopsidae, a new neritopsoidean family from the Upper Triassic (upper Carnian to lower Norian) of the Wallowa terrane, northeastern Oregon. Journal of Czech Geological Society 46, 307-318.

BöHM, J. 1895. Die Gastropoden des Marmolatakalkes. Palaeontographica 42, 211-308.

BoggiLD, O.B. 1930. The shell structure of the molluscs. Det Kongelige Danske Videnskabernes Selkabs Skrifter, Naturvidenskabelig og Mathematisk Afdeling 9, 231-326.

Bouchet, P. \& Rocroi, J.-P. 2005. Classification and nomenclator of gastropod families. Malacologia 47, 1-397.

Bourne, G.C. 1908. Contributions to the morphology of the group Neritacea of aspidobranch gastropods. Part I. The Neritidae. Proceedings of the Zoological Society of London 1908, 810-887.

Brösamlen, R. 1909. Beitrag zur Kenntnis der Gastropoden des schwäbischen Jura. Palaeontographica 56, 177-321.

BrolLI, F. 1907. Die Fauna der Pachycardientuffe der Seiser Alp. Scaphopoden und Gastropoden. Palaeontographica 54, 69-138.

Cossmann, M. 1898. Referat Koken: Die Gastropoden der Trias von Hallstadt. Revue critique de paléozoologie 2, 148-150.

Cossmann, M. 1925. Essais de Paléontologie Comparée. Treizième Livraison. 345 pp. Les Presses Universitaires de France, Paris.

Diener, C. 1926. Fossilium Catalogus I: Animalia, Pars 34 Glossophora triadica. 242 pp. W. Junk, Berlin.

FRETTER, V. \& GRAHAM, A. 1962. British prosobranch molluscs, their functional anatomy and ecology. 755 pp. Ray Society, London.

FRÝDA, J. 2000. Some Givetian (late Middle Devonian) gastropods from the Paffrath area (Bergisches Land, Germany). Memoirs of the Queensland Museum 45, 359-374.
FRÝDA, J. \& BANDEL, K. 1997. New Early Devonian gastropods from the Plectonotus (Boucotonotus)-Palaeozygopleura Community in the Prague Basin (Bohemia). Mitteilungen aus dem Geologisch-Paläontologischen Institut der Universität Hamburg 80, 1-57.

Frýda, J., Blodgett, R.B. \& Stanley, G.D. 2003. New neritopsoidean gastropods (Neritimorpha) from the Late Triassic (Late Carnian-Early Norian) of the Wallowa Terrane, northeastern Oregon. Mitteilungen aus dem Geologisch-Paläontologischen Institut der Universität Hamburg 87, 55-72.

FÜRSICH, F.T. \& WENDT, J. 1977. Biostratinomy and palaeoecology of the Cassian Formation (Triassic) of the southern Alps. Palaeogeography, Palaeoclimatology, Palaeoecology 22, 257-323.

Golikov, A.N. \& Starobogatov, Y.I. 1975. Systematics of prosobranch gastropods. Malacologia 15(1), 185-232.

Gordon, M. \& Yochelson, E.L. 1982. A Naticopsis operculum found in situ (Gastropoda: Mississippian). Journal of Paleontology 56, 260-265.

GRÜNDEL, J. 1980. Zur Gastropodenfauna des Unteren Muschelkalkes im Raume Halle-Unstruttal (DDR). Freiberger Forschungshefte C348, 41-59.

HAAs, O. 1953. The Late Triassic gastropods from Central Peru. Bulletin of the American Museum of Natural History 101, 9-328.

HASZPRUNAR, G. 1988. On the origin and evolution of the major gastropod groups, with special reference to the Streptoneura. Journal of Molluscan Studies 54, 367-441.

Heidelberger, D. 2001. Mitteldevonische (Givetische) Gastropoden (Mollusca) aus der Lahnmulde (südliches Rheinisches Schiefergebirge). Geologische Abhandlungen Hessen 106, $1-291$.

Heidelberger, D. \& BAndel, K. 1999. Micromorph Gastropoda from the Middle Devonian (Givetian) limestone of the Soetenich Syncline (Eifel). Mitteilungen aus dem Geologisch-Paläontologischen Institut der Universität Hamburg 83, 129-162.

Herholz, M. 1992. Mikromorphe Gastropoden aus dem rheinisch-westfälischen Steinkohlerevier (Oberkarbon). Neues Jahrbuch für Geologie und Paläontologie, Monatshefte 1992, 242-256.

HoLTHUIS, B.V. 1995. Evolution between marine and freshwater habitats: a case study of the gastropod Neritopsina. 286 pp. Doctoral dissertation, University of Washington.

JAGT, J.W.M. \& JANSSEN, A.W. 1988. Jouannetia (Bivalvia, Pholadidae) and Neritopsis (Gastropoda, Neritopsidae), two mollusks from the Danian (Paleocene) of the Maastricht area (SE Netherlands and NE Belgium). Mededelinden Werkgroep voor Tertiare en Kwartaire Geologie 25, 163-174.

JefFery, D.L., HoAre, R.D., Mapes, R.H. \& Brown, C.L. 1994. Gastropods (Mollusca) from the Imo Formation (Mississip- 
pian, Chesterian) of north-central Arkansas. Journal of Paleontology 68, 58-79.

KAIM, A. \& SzTAJNER, P. 2005. The opercula of neritopsid gastropods and their phylogenetic importance. Journal of Molluscan Studies 71, 211-219.

KAnO, Y., ChiBA, S. \& KASE, T. 2002. Major adaptive radiation in neritopsine gastropods estimated from 28S rRNA sequences and fossile records. Proceeding of the Royal Society 2699, 2457-2465.

Kano, Y. \& Kase, T. 2000. Taxonomic revision of Pisulina (Gastropoda: Neritopsina) from submarine caves in the tropical Indo-Pacific. Paleontological Research 4, 107-129.

KitTL, E. 1892. Die Gastropoden der Schichten von St. Cassian der südalpinen Trias. Part 2. Annalen des kaiserlich-königlichen naturhistorischen Hofmuseums 7, 35-97.

KitTL, E. 1894. Die triadischen Gastropoden der Marmolata und verwandter Fundstellen in den weissen Riffkalken Südtirols. Jahrbuch der Kaiserlich-königlichen geologischen Reichsanstalt 44 (1894), 99-182.

KiTTL, E. 1899. Die Gastropoden der Esinokalke, nebst einer Revision der Gastropoden der Marmolatakalke. Annalen des kaiserlich-königlichen naturhistorischen Hofmuseums 14, $1-237$.

KITTL, E. 1901. Bakonyi Triasz-Gastropodák. 54 pp. Budapest.

KLIPSTEIN, A.V. 1843. Beiträge zur geologischen Kenntnis der östlichen Alpen. 311 pp. Georg Friedrich Geyer, Giessen.

KNight, J.B. 1941. Paleozoic gastropod genotypes. Bulletin of the Geological Society of America, Special Paper 32, $1-510$.

Knight, J.B., Cox, L.R., KeEn, A.M., Batten, R.L., YochelSON, E.L. \& Robertson, R. 1960. Part I, Mollusca. Systematic descriptions, I169-I351. In Moore, R.C. (ed.) Treatise on Invertebrate Paleontology. University of Kansas Press, Lawrence.

KoninCK, L. de 1853. Notes sur le genre Hypodema. Mémoires de la Societé Royale des Sciences de Liége 8, 140-144.

KoKEN, E. 1889. Über die Entwicklung der Gastropoden vom Cambrium bis zur Trias. Neues Jahrbuch für Mineralogie, Geologie und Paläontologie, suppl. vol. 6, 305-484.

KoKen, E. 1892. Über die Gastropoden der rothen Schlernschichten nebst Bemerkungen über Verbreitung und Herkunft einige triassischer Gattungen. Neues Jahrbuch für Mineralogie 1892(2), 25-36.

KoKen, E. 1897. Die Gastropoden der Trias von Hallstatt. Abhandlungen der Kaiserlich- königlichen geologischen Reichsanstalt in Wien 17(4), 1-112.

Kues, B.S. \& Batten, R.L. 2001. Middle Pennsylvanian gastropods from the Flechado Formation, North-Central New Mexico. Journal of Paleontology, Memoir 54, Supplement 1(75), $1-95$.

Laube, G.C. 1869. Die Fauna der Schichten von St. Cassian.
Kaiserliche Akademie der Wissenschaften, Denkschrift 30, $1-48$.

LeOnARdi, P. \& Fiscon, F. 1959. La fauna Cassiana di Cortina d'Ampezzo. 3. Gasteropodi. Memorie degli Istituti di Geologia e Mineralogia dell'Università di Padova 21, 1-103.

MoJsisovics, E. von 1879. Die Dolomit-Riffe von Südtirol und Venetien. Beiträge zur Bildungsgeschichte der Alpen. 552 pp. Hölder, Wien.

MüNSTER, G.G. voN 1841. Beschreibung und Abbildung der in den Kalkmergelschichten von St. Cassian gefundenen Versteinerungen, 25-152. In Wissmann, H.L. \& Münster, G.G. Beiträge zur Geologie und Petrefacten-Kunde des südöstlichen Tirol's vorzüglich der Schichten von St. Cassian 4. Buchner, Bayreuth.

NütZEL, A. \& ERwIN, D.H. 2004. Late Triassic (Late Norian) gastropods from the Wallowa Terrane (Idaho, USA). Paläontologische Zeitschrift 78, 361-416.

NütZel, A. \& Senowbari-Daryan, B. 1999. Gastropods from the Later Triassic (Norian-Rhaetian) Nayband Formation of central Iran. Beringeria 23, 93-132.

Ponder, W.F. \& LindBerG, D. 1997. Towards a phylogeny of gastropod molluscs: an analysis using morphological characters. Zoological Journal of the Linnean Society 119, 83-265.

ROBERTSON, R. 1971. Scanning electron microscopy of planktonic larval marine gastropod shells. The Veliger 14(1), 1-12.

SASAKI, T. 1998. Comparative anatomy and phylogeny of the Recent Archaeogastropoda (Mollusca: Gastropoda). The University Museum, The University of Tokyo, Bulletin 38, 1-223.

SASAKI, T. 2001. Macro- and microstructure of shell and operculum in two recent gastropod species, Nerita (Theliostyla) albicilla and Cinnalepeta pulchella (Neritopsina Neritoidea). Palaeontological Research 5, 21-31.

ScotT, B.J. \& KenNy, R. 1998. Superfamily Neritoidea, 694-702. In Beesley, P.L., Ross, G.J.B. \& Wells, A. (eds) Mollusca, The Southern Synthesis. Fauna of Australia 5, Part B. Commonwealth Scientific and Industrial Research Organization, Canberra.

SuZuki, S., Togo, Y. \& Uozumi, S. 1991. Exosceletal adaptations for life environment in neritacean gastropods, 397-401. In Suga, S. \& Nakahara, H. (eds) Biological Systems. Springer Verlag, Tokyo.

THIELE, J. 1929-1931. Handbuch der systematischen Weichtierkunde. Gustav Fischer Verlag, Jena.

TICHY, G. 1980. Über die Erhaltung von Farben und Farbmustern an traissischen Gastropoden-Gehäusen (Colour retention in Triassic gastropods). Verhandlungen der Geologischen Bundesanstalt A 1980(2), 175-217.

Thompson, F.G. 1980. Proserpinoid land snails and their relationships within the Archaeogastropoda. Malacologia 20, 1-33.

Troschel, F.H. 1856. Das Gebiss der Schnecken zur Beg- 
ründung einer natürlichen Classification 1. 252 pp. Nicolaische Verlagsbuchhandlung, Berlin.

Troschel, F.H. \& Thiele, J. 1865-1893. Das Gebiss der Schnecken zur Begründung einer natürlichen Classification 2. 409 pp. Nicolaische Verlagsbuchhandlung, Berlin.

URLICHS, M. 1974. Zur Stratigraphie und Ammonitenfauna der Cassianer Schichten von Cassian (Dolomiten/ Italien). Schriftenreihe der Erdwissenschaftlicher Kommission 2, 207-222.

URLICHS, M. 1994. Trachyceras Laube, 1869 (Ammonoidea) aus dem Unterkarn (Obertrias) der Dolomiten (Italien). Stuttgarter Beiträge zur Naturkunde, Serie B 217, 1-55.

WendT, J. 1982. The Cassian patch reefs (Lower Carnian, Southern Alps). Facies 6, 185-202.

WENZ, W. 1938-1944. Gastropoda, Teil I. 1639 pp. In ScHINDEwolf, O.H. (ed.) Handbuch der Paläozoologie, Bd. 6. Gebrüder Borntraeger, Berlin.

Wilson, B.R. 1993. Australian marine shells. Prosobranch gastropods. Part 1 (Prosobranch gastropods). 408 pp. Odyssey Publishing, Kallaroo, Western Australia.
Yin, H.-F. \& Yochelson, E.L. 1983. Middle Triassic Gastropoda from Qingyan, Ghizhou Province, China: Euomphalacea and Loxonematacea. Journal of Paleontology 57, 1098-1127.

ZARDINI, R. 1978. Fossili Cassiani (Trias Mediosuperiore) Atlanti dei Gasteropodi della Formazione di S. Cassiano Raccolti della Regione Dolomitica Atorno a Cortina d'Ampezzo. 58 pp. Cortina d'Ampezzo.

ZARDINI, R. 1980. Fossili Cassiani (Trias Mediosuperiore) Atlanti dei Gasteropodi della Formazione di S. Cassiano Raccolti della Regione Dolomitica Atorno a Cortina d'Ampezzo. 14 pp. Cortina d'Ampezzo.

ZARDINI, R. 1985. Fossili Cassiani (Trias Mediosuperiore) Atlanti dei Gasteropodi della Formazione di S. Cassiano Raccolti della Regione Dolomitica Atorno a Cortina d'Ampezzo. 16 pp. Cortina d'Ampezzo.

ZitTEL, K.A. 1873. Die Gastropoden der Stramberger Schichten. Paläontologische Mittheilungen aus dem Museum des königlich Bayrerischen Staates 2, 311-491.

Zittel, K.A. 1895. Grundzüge der Palaeontologie. 971 pp. R. Oldenbourg, München and Leipzig. 